\title{
SURVEY OF ARTIFICIAL PRODUCTION
}

OF ANADROMOUS SALMONIDS

IN THE COLUMBIA RIVER BASIN

Final Report 1985

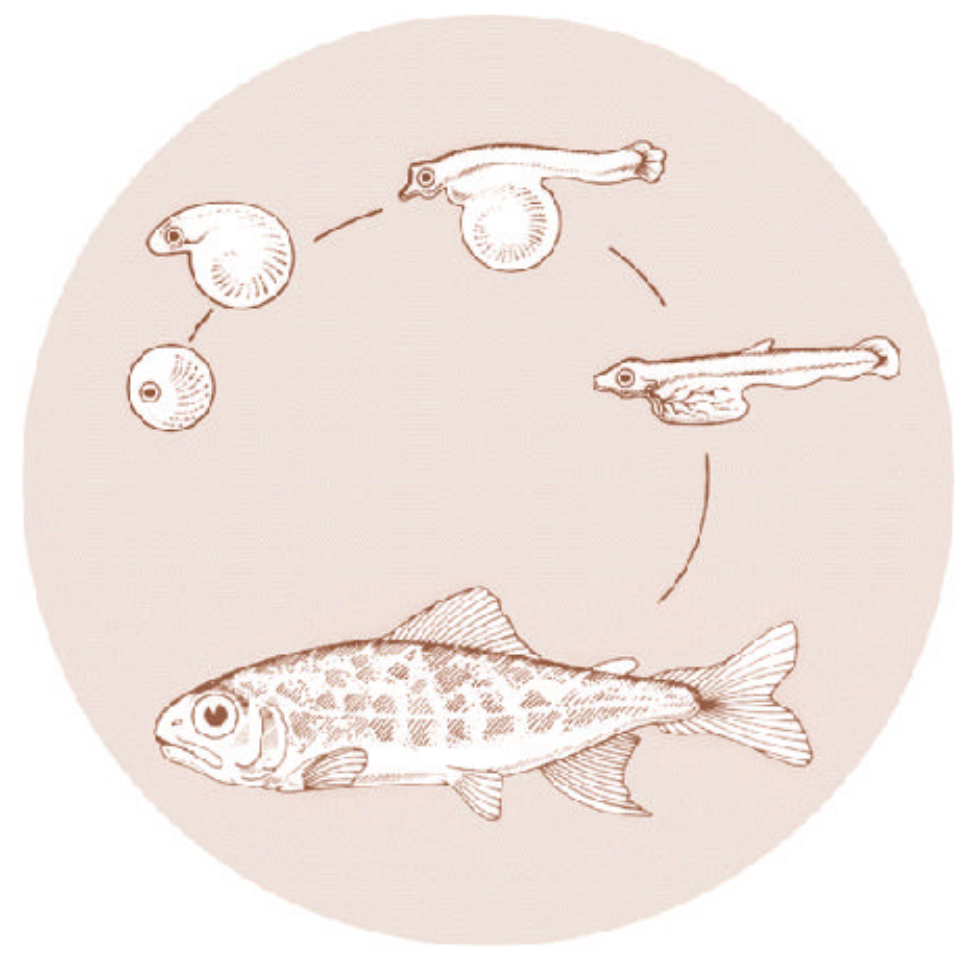

DOE/BP-17100-1 
This report was funded by the Bonneville Power Administration (BPA), U.S. Department of Energy, as part of BPA's program to protect, mitigate, and enhance fish and wildlife affected by the development and operation of hydroelectric facilities on the Columbia River and its tributaries. The views of this report are the author's and do not necessarily represent the views of BPA.

This document should be cited as follows:

Dr. Percy Washington - GAIA Northwest Incorporated, Survey Of Artificial Production Of Anadromous Salmonids In The Columbia River Basin, Final Report 1985, Report to Bonneville Power Administration, Contract No. 1984BP17100,

Project No. 198405100, 229 electronic pages (BPA Report DOE/BP-17100-1)

This report and other BPA Fish and Wildlife Publications are available on the Internet at:

\section{http://www.efw.bpa.gov/cgi-bin/efw/FW/publications.cgi}

For other information on electronic documents or other printed media, contact or write to:

Bonneville Power Administration

Environment, Fish and Wildlife Division

P.O. Box 3621

905 N.E. 11 th Avenue

Portland, OR 97208-3621

Please include title, author, and DOE/BP number in the request. 


\section{SURVEY OF ARTIFICIAL PRODUCTION OF ANADROMOUS SALMONIDS IN THE COLUMBIA RIVER BASIN}

Final Report 1985

Prepared by

Dr. Percy Washington, Project Leader

Funded by

Ron Morinaka, Project Manager

U.S. Department of Energy

Bonneville Power Administration

Division of Fish and Wildlife

Contract No. DE-AI-7984BP17100

Project No. 84-51

November 25, 1985 
Acknowledgments

This project could not have been completed without the cooperation and interest of the various agencies concerned with the anadromous fish runs of the Columbia River system. Agency personnel devoted a considerable amount of effort to assembling information for the project, even though each person involved had other important responsibilities, We especially thank the hatchery supervisors and staffs for the time they expended in providing data. Without their advice and assistance there could have been no project. Agencies most active in providing data and their liaison representative for the project were:

Chelan County PUD, Steven Hayes

Washington Department of Game, James Gearheard

Washington Department of Fisheries, Robert W. Foster

Oregon Department of Fish and Wildlife, Michael Stratton and Jerry Bauer

National Marine Fisheries Service, Einar Wold

Idaho Department of Fish and Game, Evan Parrish

US Army Corps of Engineers, Joseph McMichael

Douglas County PUD, Michael Erho

Grant County PUD, Michael Dell

Idaho Power Company, Larry Wimer

US Fish and Wildlife Service, Henry E. Forner

Others who provided assistance at various stages of the project include Kenneth Kral and Donald Caha, City of Tacoma Department of Utilities; Tom Scribner, Yakima Indian Nation; James Warren, US Fish and Wildlife Service; John Schandl and James Wood, Washington Department of Fisheries; and Wallace Hublou, Oregon Department of Fish and Wlife (retired).

We also thank the many support personnel of the various agencies who answered our questions and searched for the information we needed for the project,

Finally we wish to thank Gerald Bouck and Ron Morinaka, Technical Representatives for BPA, for their patience and encouragement in solving the problems that inevitably arise during the course of a large contract. 


\section{CONTENTS}

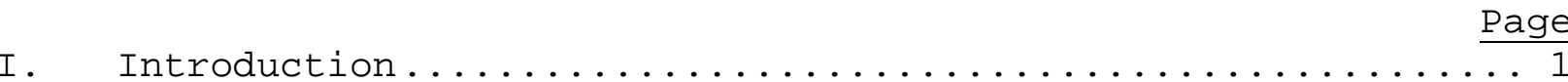

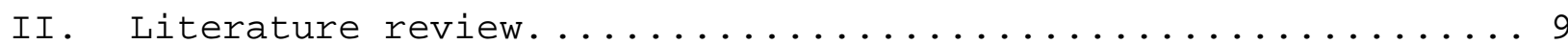

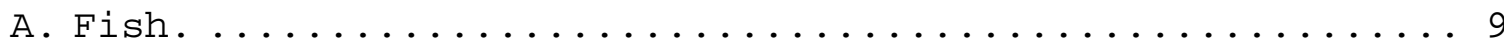

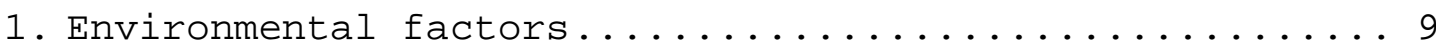

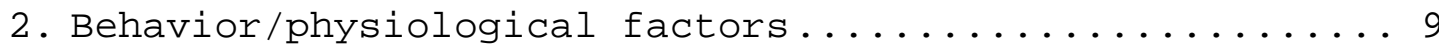

3. Factors related to fragility of the organism........10

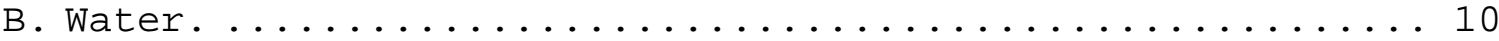

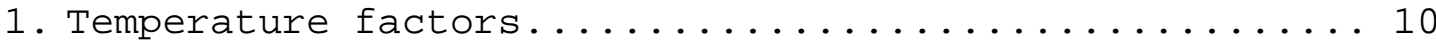

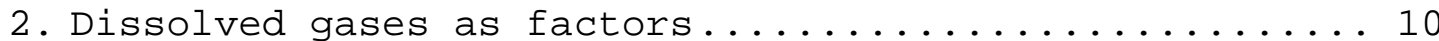

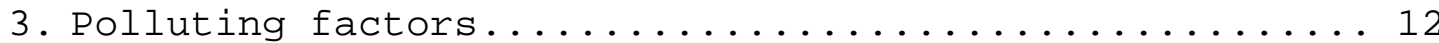

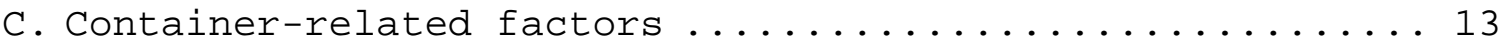

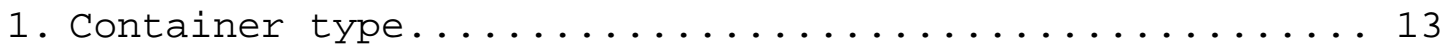

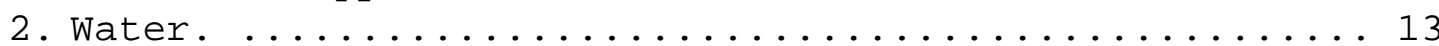

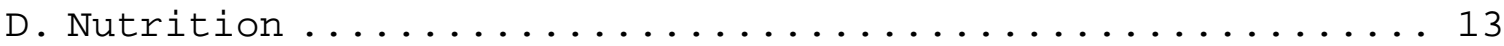

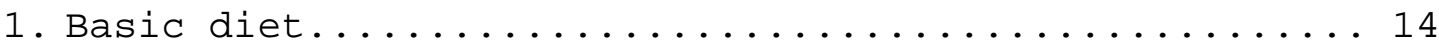

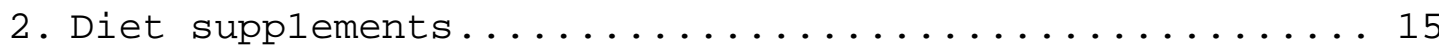

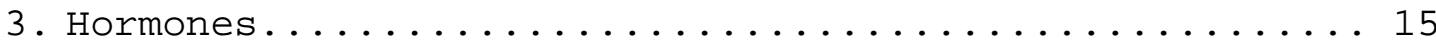

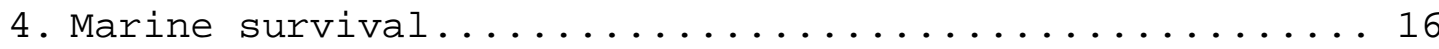

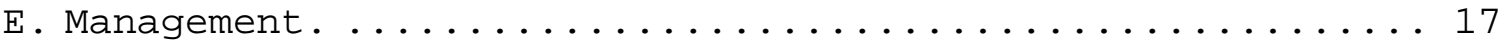

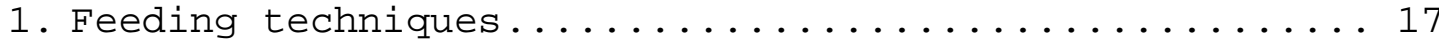

2. Fish sizing and grading techniques in relation

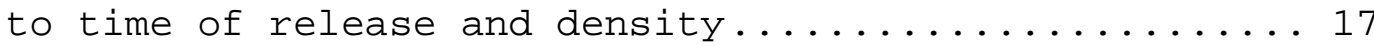

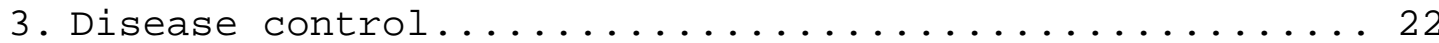

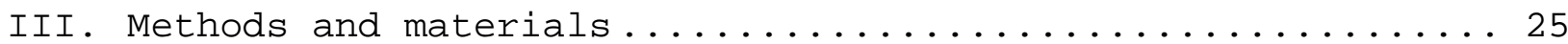

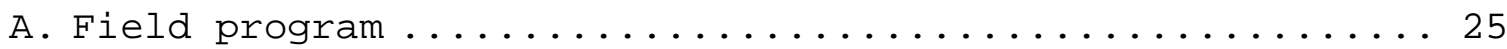

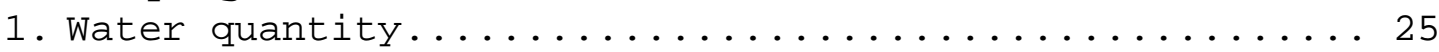

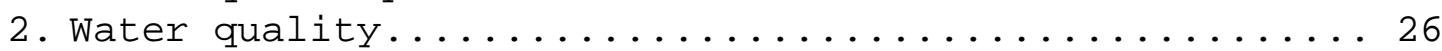

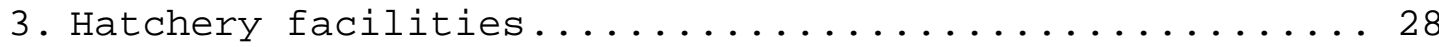

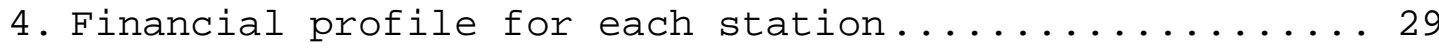

5. Standard calculation to achieve full production......30

6. Summary of facilities and costs to achieve full

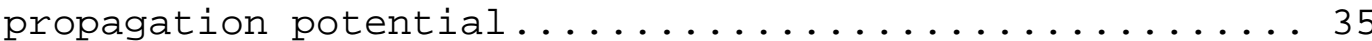

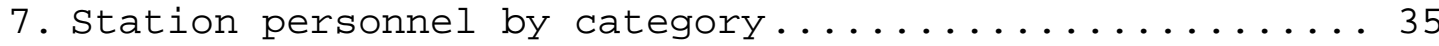

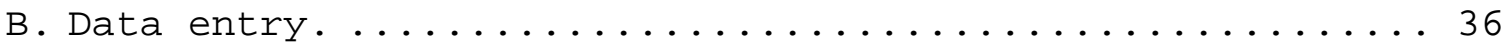

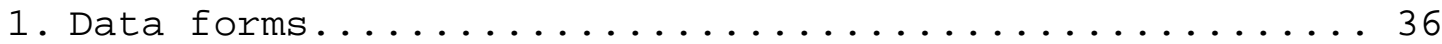

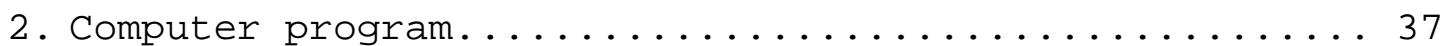

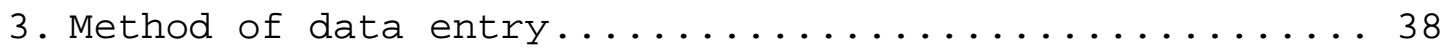




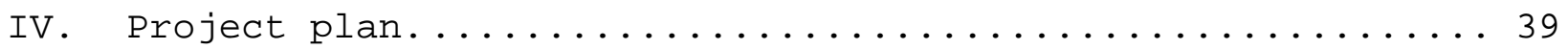

Unit 1. Identify data in central repositories.......... 39

Unit 2. Record data from central repositories.......... 40

Unit 3. Test field procedures.................. 40

Unit 4. Acquire data from Region IV ................ 40

Unit 5-7. Acquire data from Regions I-III............. 43

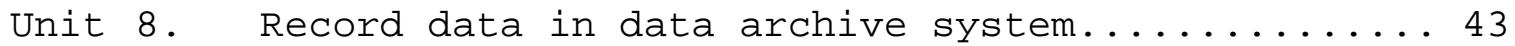

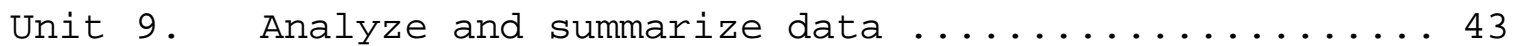

Sub-unit 1 . Develop an operating financial profile

for each station for 1981-1983 .........44

Sub-unit 2. Estimate costs to achieve

full propagation potential ...........44 44

Sub-unit 3. Record current production level

by species and estimate full propagation

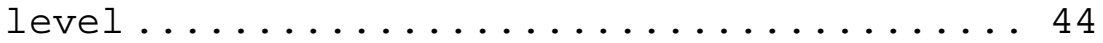

Sub-unit 4. Summarize for each station

current personnel by category ..........44 44

Unit 10. Provide data appendices and data archive.......45

Unit 11. Prepare facility site plans .............. 46

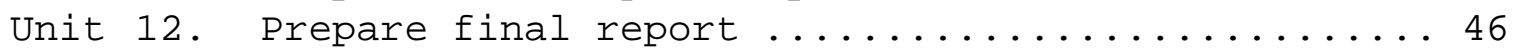

Literature cited and additional technical reports ..........47

\section{Appendices}

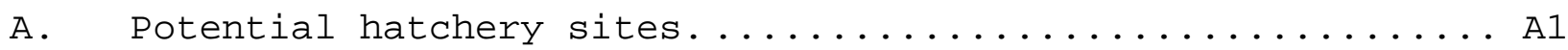

B. Full production and cost of required modifications........ B1

C. Data base (distributed separately)

1. Data printouts

2. Data archive (floppy disks)

D. Hatchery summaries 


\section{TABLES}

Table

$1 \quad$ Propagation facilities $\ldots \ldots \ldots \ldots \ldots \ldots \ldots \ldots \ldots \ldots \ldots$

2 On-site water characteristics and methods of analysis .. 27

3 Actual and potential production and costs to

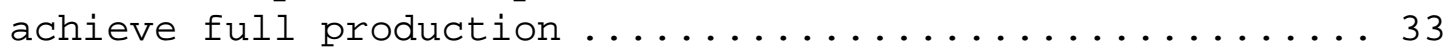

4 Site visit protocol check list ................ 41 


\section{Introduction}

The salmon and steelhead runs of the Columbia River system partially, and in some instances entirely, result from releases of fish from hatchery facilities and rearing sites. All of the propagation stations in Table 1 are operated by the US Fish and Wildlife Service and by the states of Oregon, Washington, or Idaho. Funding for these facilities is by the states and the federal government, public utility districts, and private electric utilities. Federal funds are provided primarily to mitigate the effects of federal dams.

Because the fish propagation facilities are so important to aintaining and increasing salmon and steelhead runs in the Columbia River system and because building and maintaining the hatcheries is so costly,it is essential that basic data are made available about fish production, quality and quantity of water, cost and condition of facilities, and potential for expansion. The states of Oregon, Washington, and Idaho and the US Fish anh Wildlife Service have collected much information of this type. This report summarizes such information In a single data archive available for use by various public entities.

The overall objective of this project is to collect, organize, and summarize data concerning anadromous fish culture stations of the Columbia River system for 1981,1982 , and 1983 and to create a data archive system with a means of making this information available to the public. 
Immediately after each of the following specific objectives is a reference number (or numbers) in parentheses which relates each objective to task numbers in the Request for Proposal (KFP). These reference numbers also appear in the body of this report. Specific objectives of the project are to:

1. Keview the significant literature relating to hatchery production of salmon and steelhead and discuss factors that control fish production. (1.1)

2. Describe each hatchery facility, prepare a site plan, and record current level of personnel. $(2.6,3.1,3.4)$

3. Keport on water quality and quantity at each station. $(2.4,2.4 .1,2.4 .2,2.5)$

4. Keport fish culture data for each station for 1981-1983 and record recent available production goals. (2.7, 3.2)

5. Kecord financial profiles for each station for 1981$1983 .(2.8)$

6. Estimate full propagation potential for each station. $(3.1,3.2)$

7. Estimate capital and operational costs to achieve full propagation potential at each station. (3.1)

8. Kecord published and unpublished technical documents relating to the fish-rearing operation at each site. $(1.0,1.3)$

9. List potential sites for hatchery facilities identified by fishery agencies. ( 2.10$)$

10. Provide a computerized data archive of all information collected at each station and at agency headquarters. $(5.0)$ 
TABLE 1

PROPAGATION FACILITIES

REGION I (Columbia Kiver below Bonneville Dam)

\section{Facility}

1. Abernathy National Fish Hatchery

2. Alder Creek Pond

3. beaver Creek Hatchery

4. Big Creek Fish Hatchery

5. Big White Salmon Kearing Pond

6. Bonneville Fish Hatchery

7. Cascade Fish Hatchery

8. Clackamas Hatchery

9. Cowlitz Salmon Hatchery

10. Cowlitz Trout Hatchery and

Keari ng Ponds

Il. Deer Springs

12. Eagle Creek National Fish Hatchery

13; Elokomin Salmon Hatchery

14. a. Gnat Creek Fish Hatchery

b. Trojan Rearing Pond

15. Gobar Pond

1b. Grays River Salmon Hatchery

17. Grays Kiver Salmon Pond (Meyco Pond)

18. Kalama Falls Salmon llatchery

19. Klaskanine Fish Hatchery

20. Leaburg Fish Hatchery

\section{Location}

Longvi ew, WA

Tout le, WA

Cat hlamet, WA

Astoria, OK

Underwood, WA

Bonneville, OK

Uonnevi l le, OK

Clackamas, OK

Salkum, WA

Winlock, WA

Tout le, WA

Estacada, OK

Cathlanet, WA

Cla tskanie, $0 \mathrm{R}$

Kalarna, WA

Grays Kiver, WA

Grays Kiver, WA

KA lama, WA

Astoria, OK

Leaburg, OK
Operating agency*

us F. d w. s.

WA D. of G.

WA D. of G.

OK D. of F. \& W.

us F. \& w. s.

OK D. of F. \& W.

OK D. of F.\& w.

OK D. of $\mathbf{F} . \& W$.

WA D. of $r$.

WA D. of G.

WA D. of $G$.

us F. \& w. s.

WA D. of $r$.

OK D. of F. \& W.

\footnotetext{
* Agency names are given in full at the end of Table 1.
} 
$\underline{\text { Facility }}$

21. Lewis River Salmon Hatchery

22. Lower Kalama Salmon Hatchery

23. Marion Forks Fish Hatchery

24. McKenzie Fish Hatchery

25. Mossyrock Trout Hatchery

26. a. Oxbow Fish Hatchery, Herman Creek Rearing Pond

b. Wahkenna Rearing Pond

27. Roaring River Fish Hatchery

28. Sandy Fish Hatchery

29. Slcamania Trout Hatchery

30. a. South Santiam Fish Hatchery

b. Stayton Rearing Ponds

c. Aumsville Pond

31. Speelyai Salmon Hatchery

32. Toutle Hatchery

33. Vancouver Trout Hatchery and Rearing Pond

34. Washougal Salmon Hatchery

35.
a. Willamette Fish Hatchery
b. Dexter Rearing Pond

$\underline{\text { Location }}$

Woodland, WA

Kalama, WA

Idanha, OR

Leaburg, OR

Mossyrock, WA

Cascade Locks, OR

Scio, OR

Sandy, OR

Washougal, WA

Sweet Home, OR

Ariel, WA

Toutle, WA

Vancouver, WA

Washougal, WA

Oakridge, OR
Operating agency

WA D. of F.

WA D. of F.

OR D. of F. \& W.

OR D. of F. \& W.

WA D. of G.

OR D. of F. \& W.

OR D. of F. \& W.

WA D. of G.

OR D. of F. \& W.

WA D. of F.

WA D. of F.

WA D. of $G$.

WA D. of F.

OR D. of F. \& W.

REGION II (Columbia River between Bonneville Dam and Snake River confluence)

36. Carson National Fish Hatchery

37. Fall River Fish Hatchery

38. Goldendale Trout Hatchery
Carson, WA

La Pine, OR

Goldendale, WA
US F. \& W. S.

OR D. of F. \& W.

WA D. of G. 
TABLE 1 (continued)

$\underline{\text { Facility }}$

39. Irrigon Hatchery

40. Klickitat Salmon Hatchery

41. Little White Salmon National

Fish Hatchery

42. Oak Springs Fish Hatchery

43. Round Butte Fish Hatchery

44. Spring Creek National Fish Hatchery

45. Warm Springs National Fish Hatchery

46. Willard National Fish Hatchery

47. Wizard Falls Fish Hatchery $\underline{\text { Location }}$

Irrigon, OR

Glenwood, WA

Cook, WA

Maupin, OR

Madras, OR

Underwood, WA

Warm Springs, OR

Cook, WA

Camp Sherman, OR $\underline{\text { Operating agency }}$

Ok D. of F. \& W.

WA D. of F.

US F. \& W. S.

OR D. of F. \& W.

OR D. of F. \& W.

US F. \& W. S.

US F. \& W. S.

US F. \& W. S.

OR D. of F. \& W.

REGION III (Columbia River System above the Snake River Confluence)

48. Chelan Trout Hatchery

49. Entiat National Fish Hatchery

50. Leavenworth National Fish Hatchery

51. a. Naches Trout Hatchery

b. Nelson Springs

52. Nile Spring Hatchery

53. Omak Trout Hatchery

54. Priest Rapids Salmon Hatchery

55. a. Ringold Springs Salmon Rearing

Pond

L. Rlngold Springs Steelhead

Rearing Pond
Chelan Falls, WA WA D. of G.

Entiat, WA

US F. \& W. S.

Leavenworth, WA

US F. \& W. S.

Naches, WA

WA D. of G.

Naches, WA

WA D. of G.

Yakima, WA

Omak, WA

Mattawa, WA

Mesa, WA

WA D. of $G$ 
TABLE 1 (continued)

$\underline{\text { Facility }}$

56. a. Rocky Reach Channel and Annex

b. Turtle Rock Rearing Pond

57. Spokane Hatchery

58. Washburn Island Rearing Facility

59. Wells Salmon and Trout Hatchery

60. Winthrop National Fish Hatchery

61. Yakima Trout Hatchery $\underline{\text { Location }}$

E. Wenatchee, WA

E. Wenatchee, WA

Spokane, WA

Brewster, WA

Pateros, WA

Winthrop, WA

Yakima, WA
Operating agency

WA D. of F.

WA D. of $G$

WA D. of G.

WA D. of G.

WA D. of F. and

WA D. of G.

US F. \& W. S.

WA D. of G.

\section{REGION IV (Snake River System)}

62. Dworshak National Fish Hatchery

63. Eagle Hatchery

64. Hagerman National Fish Hatchery

65. Hagerman State Fish Hatchery

66. Hayden Creek Hatchery

67. Kooskia National Fish Hatchery

68. Lookingglass Hatchery

69. Lyons Ferry Salmon Hatchery

70. Lyons Ferry Trout Hatchery

71. McCall Hatchery

72. Niagara Springs Hatchery

73. Oxbow Hatchery

74. Pahsimeroi Hatchery

75. Rapid River

76. Red River Rearing and Spawning Station Red River,ID

77. Sawtooth Hatchery
Ahsahka, ID

Eagle, ID

Hagerman, ID

Hagerman, ID.

Lemhi, ID

Kooskia, ID

Elgin, OR

Lyons Ferry, WA

Lyons Ferry, WA

McCall, ID

Wendell, ID

Oxbow, OR

Ellis, ID

Riggins, I D

Stanley, ID
US F. \& W. S.

ID D. of F. \& G.

US F. \& W. S.

ID D. of F. \& G.

ID D. of F. \& G.

US F. \& W. S.

OR D. of F. \& W.

WA D. of F.

WA D. of G.

ID D. of F. \& G.

ID D. of F. \& G.

ID D. of F. \& G.

ID D. of F. \& G.

ID D. of F. \& G.

ID D. of F. \& G.

ID D. of F. \& G. 
TABLE 1 (continued)

$\underline{\text { Facility }}$

78. Tucannon Salmon and Trout Hatchery

79. a. Wallowa Fish Hatchery

b. Imnaha (Trap Acclimation) Pond

c. Little Sheep (Trap Acclimation) Pond

\section{Location}

Pomeroy, WA

Enterprise, OR

Operating agencies:

US F. \& W. S. United States Fish and Wildlife Service

ID D. of F. 6 G. Idaho Department of Fish and Game

OR D. of F. \& W. Oregon Department of Fish and Wildlife

WA D. of F. Washington Department of Fisheries

WA D. of G. Washington Department of Game 


\section{I . Literature review}

Over the past two decades, investigators have intensified research on factors affecting salmonid production at hatcheries on the Columbia River system. Klontz et al.(1979) and Downey and Klontz (1981) proposed general categories of factors affecting salmonid production at fish-rearing facilities. The following review of major factors affecting hatchery production is based on the Downey and Klontz (1981) categories. References to the literature are provided under categories of particular relevance to this hatchery survey project.

\section{A. Fish}

The fish category includes factors that relate directly to the requirements of the organism.

\section{Environmental factors}

Environmental factors refer to basic physical and chemical requirements of salmonids such as spawning substrate, stream-flow needs at various stages of development, water quality, and rearing habitat. These factors, as they relate to hatchery production, are discussed in sections B, C, and D. See Brett (1979) for a general discussion on the relation of environmental factors to growth.

\section{Behavior/physiological factors}

Salmonid behavior affecting production after hatchery release includes feeding, migrating, and predator-prey interactions. Of primary concern are behaviors that result from hatchery management practices and influence fish returns (see Sections E.1 and E.2). Salmonid physiological research hasconcentrated on the use of sex and growth hormones to increase production (Schreck and Fowler 1982 
and Schreck 1982). Plasma and gill Na+ - K+ ATP activity and thyroid hormone levels have been used to predict release times (Folmar and Dickhoff 1891). Development of osmoregulatory ability during smoltification and smolt-parr reversal was discussed by Yolmar et al. ( 1982 ).

3. Factors related to fragility of the organism

Researchers have recently given attention to quantifying embryo mortality and sensitivity caused by handling techniques and effects of incubators (Jensen and Alderdice 1983 and Johnson et al.1983).

\section{b. Wat er}

The "water" category refers to water quantity (minimal flow needs of hatcheries) and quality (such as pollutants, temperature, and dissolved gases). This review emphasizes water characteristics ( qua lity).

\section{Temperaturefactors}

Research on salmonid sensitivity to temperature ranges has been related to dissolved oxygen availability and rate of oxygen uptake; embryonic development; protein, lipid and fatty acid composition in muscle tissue; feeding; growth; acclimatization and tolerance; and such factors as mobility, aggression and stress (Akepshire et al. 1983, brett 1952, Goff and Yorsyth 1979, and Hemming et al. 1982).

2. Dis solved gases as factors

Specific references to nitrogen supersaturation, dissolved ammonia, and carbonic acid are found in those references listed in the section on polluting factors (U.3). Many investigators have studied dissolved oxygen requirements in relation to temperature and the carrying capacities of rearing Facilities..There has been 
little agreement among hatchery managers about the optimum carrying capacity of troughs or ponds. Haskell's (1955) equations for optimum biomass of brown trout per volume of pond may have overlooked several factors that influence the amount of water needed for fish propagation, such as the oxygen uptake of fish at given activity and water temperatures. beamish and Dickie (1967) reported that oxygen consumption increased wi th increased activity and temperature. Oxygen uptake for active fish decreased as ambient oxygen levels decreased, and as carbon dioxide and loading density increased (Wells 1935 , Privone 1950 , and beamish 1964). Basu (1959) demonstrated that the logarithm of the rate of activity vs. oxygen consumption decreased linearly with increased partial pressure of carbon dioxide.

burrows and Combs (1968) reported that pond carrying; capacity for fingerling chinook salmon (biomass per flow) was inversely proportional to water temperature and proportional to fish size. Willoughby (1968), usingHaskell's (1955) assumption, proposed that a daily food ration for fish could be estimated using their body weight and water temperature. This equation could then be used to calculate the flow required for a given fish biomass. The equation in Willoughby (1968) did not specify species or loading density. Westers (1970) considered water exchange important and reported an equation that related fish density (biomass per cubic foot of water), carrying capacity (biomass per gallon per minute), and water exchange rate (change per hour). Westers'(1970) equation accounted for most major factors except that ambient oxygen was not considered. 
Equations in Elliot (1969) for the oxygen uptake by chinook salmon seemed to apply only to the weight range tested $(1.85-17.5$ grams). Elliot did not specify loading density, which Liao (1971) contended "affects activity levels." Liao (1971) reported the inadequacy of loading density and water exchange rates when determining carrying capacity "because hydraulic patterns affect the oxygen consumption." He plotted rates of oxygen uptake at different water temperatures vs. fish sizes and derived the "saturated dissolved oxygen concentration," which is dependent upon temperature and altitude.

Other researchers have concentrated on artificial aeration systems, growth and stress dynamics at various air saturation levels, nitrogen supersaturation, and ammonia effects upon survival (Bailey et al. 1980 , Brett and Blackburn 1981, Colt and Westers 1982 , and Thruston et a l. 1981$)$.

\section{Polluting factors}

Polluting factors can be natural (such as sediment transport and deposition, water hardness, high mineral seepage into streams) or associated with human contaminants (agrlcultral, Industrial, and domestic). The effect on stress and growth of hatchery fish when transferred into water of varying $\mathrm{pH}$ has been investigated by Peterson et al. (1980) and Saunders et al. (1983). General toxicity tests relating to hatchery production have received attention as well as investigations into alkalinity and ammonia conditions (Eicher 1946 ,Finlayson and Verrue 1983 , Jordan and Lloyd 1964 , and Thompson and Paton 1976). 


\section{c. Container-related factors}

Hatchery tanks, raceways, substrate type, transport tanks, water velocity, and water replacement time are all examples of this c a te g o r y.

\section{Container type}

Fry biomass, feeding dynamics, and survival have been studied In enhanced natural channels and hatchery containers (Leon and Bonney 1979 and Acara 1977). Rearing cage and spawning substrate optimization were researched by Barns and Simpson (1976), boydstun and Hopelain (1977), and Hickey et al. (1979).

\section{Water}

Mundle and Taber (1983) examined the effects of various discharge rates on steelhead smolt yield. Literature on water flow and exchange rate requirements is reviewed in the following sections on nutrition and hatchery management.

\section{Nutritlon}

Factors in the "nutrition" category Include: 1.) percent diet composition of the basic food groups; 2.) supplements to the commercial diets to enhance growth and survival; and 3.) hormonal treatment to speed growth, increase adult returns, and facilitate saltwater transfer. The ultimate goal Is increased marine survival and returns. Salmonld culturlsts have developed fish diets based on the National Research Council (1981) publication. Still morerecent research at hatcheries and academic Institutions has led to Improved nutritional techniques. 


\section{B a sic diet}

Much research has concentrated on percent protein and lipid and on carbohydrate quality In fish diets and in the resulting composition and performance of the developing fish. Lemm and Hendrix (1981) examined Atlantic salmonld growth and survival from varlous starter diets. Fouler (1980) researched starter diets for chinook fry and later Fowler (1981) looked at which protein and energy relations in the starting diets could improve growth. The effect of the major food groups on growth, tissue composition, and food conversion in rainbow trout was studied by Bronley and Smart (1981). Steffens (1981) found a direct relation between ration amount and oxygen consumption at various temperatures while observing daily metabolic rates of fingerling sockeye. Clarke, et a 1. (1982) conducted a long-term study of the effects of varying the protein-to-lipid ratio in dry diets on coho body composition and growth rates; tests were performed at various temperatures and compared to groups fed only Oregon Moist Pellets (OMP). Markert et a 1. (1984) found that dry diets were suitable in coho culture if a similar balance of nutrients was maintained as was found in OMP. In an analysis of various types of carbohydrates, Aklyama et al. (1982) found that chum salmon fry were not efficient at utilizing more complex sugars but that simple carbohydrates such as glucose were relatively well metabolized. Of the carbohydrates studied, gelatinized potato starch was utilized the best. 


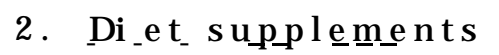

Supplements to standard diets have been a popular research subject. Fowler (1991) found better weight gains in chinook fry when cottonseed meal or brewer's grains were replaced with herring meal or poultry/feather meal; also, dogfish liver oil proved to be equivalent to tuna oil as a lipid source. Rapeseed products of the carlola type were determined to be good protein supplements for chinook fry. Rapeseed products alone could comprise $13-16$ percent of the dictary protein ( Higgs et al. 1982). When Akiyana et al. (1934) sullolmented chum salmon fish meal with silkworm pupae, dried beef liver, and krill or earthworm powder, they found that the e a r thworm supplement gave the best growth results.

\section{Hormones}

The addition of hormones to the diet, as well as manipulation of nutrient composjtions, has altered the performance of salmonids. fagerlund et a l. ( $\left.\begin{array}{llll}1 & 9 & 8 & 3\end{array}\right)$ studied the effects of eight dietary treatments on juvenile coho treatments included various concentrations of protein, lipid, and 17 -methyltestosterone (MT hormone). Fish fed high-density lipidproteins gained weight faster than either those fish on low-density lipidproteins or thosefish fed with lipidprotein mixes found in traditional diets. The protef $n$ efficiency ratio was inversely related to dietary protein and directly related to lipid content. The authors concluded that food costs in coho culture could be lowered through manipulation of dietary protein, lipid, and MT content. MT hormone and $\mathbf{T}_{\mathbf{3}}\left(\mathbf{3}, \mathbf{5}, \mathbf{3}^{\prime}-\right.$ triisdo-L-thyronjne) were found to enhance growth of coho in freshwater but only $\mathrm{T}_{3}$ faci litated saltwater transfer (Fagerlund et a l. 1980, Fagerlund e t a l.1979). However, Higgs et a l. (1983) 
found that dietary and hormonal' treatment ( $\mathrm{T}_{3}$ ) In freshwater did not influence chinook performance in seawater. Stimulation of growth by $T_{3}$ was demonstrated when the chinook's dietary protein level was around 50 percent; growth enhancement by $\mathrm{T}_{3}$ was positively correlated with the dietary concentration of canola meal and $\mathrm{T}_{3}$ as well. Thyroid and steroid hormone treatments were also examined by Higgs et al. (1982). Experiments with steelhead diets showed that diet composition had a pronounced influence on the anabolic efficacy of $\mathrm{I}_{3}$ and that $\mathrm{T}_{3}$ stimulates grouth through increasing carbohydrate utilization. In thyroid hormone feeding experiments on Atlantic salmon, Xefstie (1981) found that $\mathrm{T}_{3}$ was better than $\mathrm{T}_{4}$ for saltwater tolerance and grouth; however, both hormones could induce snoltification in underyearlings.

4. Marine s u rviv_a

Researchers recognize the need to relate growth improvement and saltwater transfer to marine survival and conribution to the fishery. Fowler (1983) examined grouth and survival of fry fall chinook salmon when dietary protein and energy utilization were manipulated. plotnikoff, et al. ( 1983 ) t ried to relate nutrition to marine survival of chinook salmon. Chinook growth and food, protein, and energy utilization were best for fish fed diets with high lipid content. The body composition of wild smotl counterparts had a higher percentage of moisture, protein, and ash but a much lower percentage of body lipid (Platnikoff, et al. 1984). These rcsearchcrs tagged and released smolts of varying percentages of protein and lipid body composition. Unfortunately, marine survival and return data were incomplete atthe time of publication. 


\section{E. Management}

Management is a very broad category that includes all research relating to general hatchery management techniques. Piper et al. (1982) gave an extensive description of hatchery management techniques. Washington (1982) thoroughly reviewed hatchery wwanagement practices and how these practices might affect hatchery producton. A few key factors that have received attention in the recent literature are as follows.

\section{Feeding techniques}

Statler (1962) investigated food-to-flesh conversion in steelhead trout-rearing experiments where self feeders were compared to hand feeders. Also compared were two diet types. Self-feeding was more cost effective and food-to-flesh conversion was about twice that of the hand-fed group.

2. Fish sizing and grading techniques in relation to time of $\underline{\text { release and density }}$

These factors have been grouped together because many researchers investigated more than one factor, such as salmonld density in hatcheries along with timing of releases, or grading techniques with rearing time.

Time of release has been identified as an important factor influencing survival rates of salmonid releases in test lots. Hatchery fish survived at higher rates when released after May (Senn et al. 1974 , Seidel and Mathews 1977, and Bilton 1980,1981). However, wild salmon (particularly coho) migrated during the first two weeks of May (Thompson and Paulik 1967). Coho release times during the 1960's were very early, between November and March, and 
survival was higher then than in recent years. Coho releases of the early 1960 's migrated during the first two weeks of May (Durkln and Sims 1975$)$. Roth catch and escapement from such releases were following an increasing trend (Bureau of Commercial Fisheries 1969 1971). The apparent Influence of time of release on survival rates was perhaps a sympton of something that occurred before release.

The size of individual salmonids released from Columbia River hatcheries has increased dramatically over the past ten years. There has been a great increase in numbers and average release size, and a relatively minor increase In total tearing space. The only new hatchery built during this period was on the Cowlitz River (Whale and Smith 1979, and Smith and Wold 1981). Bell (1973) developed guidlines for determining loading densities at Columbia River hatcheries.

Cunnes (1976) reported the effects of grading b-7.5 and 9 month Atlantic salmon fingerlings by size. Earlier separation by grading had the best effect on growth. Those graded at later ages showed little difference in growth rate from ungraded control lots. The advantages of grading were greater growth and fewer unexplained los s e s.

burrows (1969) indicated that increased survival to adulthood could result from released chinook fingerlings that had greater stamina, largersize, increased protein and energy reserves, and a lower incidence of disease. All these factors are influenced by chronic stress related to density.

Fin erosion, inadequate weight gain, relatively low protein content in muscle tissue, and outbreaks of diseases caused by stress may be correlated with long rearing time and density (Moring 1982 , 
and Specker and Schreck 1980). Ocean survival of salmonids and age composition of adult populations can be influenced by size select Ion at time of release (Fagerlund et al. 1983, and Kitter 1975). Bilton ( 1978 , 1983 ), Bilton and Jenkinson (1980) and Brannon et al. (1982) examined the effects of time and size of release as a separate production issue from rearing density factors. Mahnken et al. (1982) suggested that the critical size at releasefor optimal adult survival and return of coho salmon release has increased.

Fall chinook salmon survival rates, as determined by commercial catches and hatchery returns, were found to be best in the largest of three size groups, all of which were released at the same time (Yowler and Banks 1980); Fowler et al. (1980) also demonstrated that fall chinook reared for a longer duration and to a larger size survived at higher rates than those released at an earlier time and at a smaller size. Bilton et al. (1982) analyzed four release times (with three size groups for each time) for coho salmon. The maximum adult returns werefor large juveniles from the late release group.

Blaxter (1975) reported that intraspecific survival factors usually predominate in hatcheries and interspecific factors in the natural environment. "Fish density is ultimately the key factor in both environments because high density induces stress and competion for food as well as enhancing predation." He offered a generalization about flatflsh that is probably true for other fishes: "Growth comparisons of wild and hatchery fish stocks are difficult because of the dependence of (wild fish) growth on food supply and fish density." Other6 have reported poor performances by hatchery salmonids in comparing their stamina with that of wild fish 
of the same species (Vincent 1960 , Miller and Miler 1962 , Green 1964, , and Barns 1967).

Blaxter (1975) reported that low densities produced more uniform and larger fish than high densities. Size hierarchies as a result of high density increased variance in size and caused an increase in size-dependent mortality. Blaxter listed symptoms of high density as abnormal pigmentation, bitten fins, and impaired locomotor performance In addition to size hierarchies.

Ejike and Schreck (1980) studied the effect6 of dominance hierarchy on parr coho salmon. stress levels were inversely related to social dominance poei tion. They concluded, "It is plausible that dominancestatus is inversely related to a low-level, chronic state of stressin the fish, the dominant individual being the least stressed.

Fenderson and Carpenter (1971) reported that wild salmonids were most aggressive at low densities while hatchery fish aggressiveness Increased at intermediate and high density levels.

li and Brolenson (1977) found that increases in metabolic rates of rainbow trout at higher population densities were attributable to three factors:(1) starvation, (2) increased subordinate fish exercise level6 (dominant fish took the most suitable areas), and (3) increased levels of excitation. The "variance of energetic factors of routine metabolism, growth rate, consumption rate, and growth efficiency tended to increase with density." Allof the above were indicator6 of Intraspecific competition. Dominant individuals grew faster and contained more lipids at each density. "At higher densities, dominance conferred less benefits than was observed at lower population levels." 
Refsite and Kittelsen (1976) found that high densities of salmonids depressed growth rate and "that compensatory growth occured when the densities were standardized." High density considerably decreased Atlantic salmon growth rates. $\quad$ refsite (1977) reported similar finding 6 for rainbow trout. High density groups exhibited the lowest growth rates.

Wedeaeyer (1976) reported that density levels greater than six pound6 per cubic foot in soft water caused significant increase in stress-related hormone levels among presmolt coho salmon. This abnormal condition required at least a week for recovery. Wedemeyer recommended densities of 0.6 to 3.1 pound per cubic foot in distribution trucks, ponde, or raceway to minimize handling and the stress of crowding in soft water.

Fagerlund et al. (1983) concluded that at high densities, smoltificatlon in small coho salmon may be retarded and consequently, small fish may suffer the greatest relative loss after release. Sandercock and Stone (undated) reported that low-density release lots of coho survived at sea 1.8 time 6 better than highdensity lots. Pagerlund et al. (1979) reported similar result6 in studies of rearing density of salmon. These studies demonstrated that the effects of crowding salmon during rearing were similar to those mentioned in the review of Blaxter (1975).

Additional information on density, release time, and rearing method and how such factor relate to hatchery production can be found in Beuer (1982), Brett et al.(1978), Clarke and Blackburn (1978), Corey (1983), Ewing et al. (1980) Iwama and Tautz (1981), Nlkinmaa et al. (1983), Papst et al. (1982), and Shelbourn (1980). 


\section{Disease control}

With the increased reliance on hatchery-reared salmonids for the maintenance of populations, the potential for major upset in production from diseases has Increased. Many hatchery diseases have been recognized since the 1930 's when furunculosis was first diagnosed (Duff and Stewart 1933 ).

Gould and Wedemeyer (undated) noted that the most troublesome diseases affecting both wild and hatchery stocks of the upper Columbia Kiver basin fish are furunculosls (Aeromonas salmonlcida), columnaris (Flexlbactor columnaris), gill diseases (possibly four or five species of bacteria), bacterial kidney disease (Renibacterium salmonlnarum), enteric redmouth disease (Yerslniarucheri), saprolegnia (Saprolegnla sp.) and infectious hematopoietlc necrosis (IHN). Wood (1974) states that the most prevalent bacterial dieeases of Salmon are furunculosis bacterial gill disease, columnaris and kidney disease. For each of these diseases he gives the causative agent, type of infection, species infected, symptoms, optimum temperature, prevention, and treatment.

Many factors contribute to the onset and duration of diseases. Physical features such as crowding, low flow, temperature, and chemical factors such as low diesolved oxygen, un-ionized anmonia, and pH can have a strong Influence on the virulence and impact of an infectious agent. When a pathogen is present and the environment is favorable for disease,serious fish losses may occur (Wood 1974).

Disease organisms are commonly found in hatchery water and perhaps in a latent state in the fish themselves. Generally, in a hatchery, the environment is the controlling factor in determining whether a disease occures. For example, Yersinia rucheri has been. 
found In wild salmon stocks but not as an eplzootic. However, in hatcheries under conditions of crowding and high temperatures, high mortalities due to redmouth disease have been reported (Dulin et al. 1976). Similarly, columnarls occurs in scrap fish which may act as a reservoir. Under conditions of stress (i.e. with high temperature 6 and high densities) mortalities increase significantly (Becker and Fugihara 1978).

Development of diseases within a hatchery can have profound and immediate effects. Wood (1974) notes that explosive outbreaks of bacterial gill disease can lead to mortalities as high as 20 percent within 24 hours and as high as 50 percent within 48 hours. Katliff et al. (1982) reported 90 percent mortality within three weeks in fisn with infectious hetnatopoietic necrosis (IHN). hatchery management practice can play a significant role In the effect6 elicited by particular epizootics. Wedemeyer and Wood (1974) related the occurrence of epizootics to stress. Disease outbreaks occurred with reduced environmental quality and caused the deterioration of fish immunal systems which combat disease organisms that are always present. Management of the environmental condition 6 is the first line of defense and can minimize disease-induced losses. Management of such factors as pH, dissolved oxygen, unionized ammonia (through pH management), temperature, density, and release timing, will affect not only disease susceptibility but more generally the overall well-being of hatchery fish.

Rapid diagnosis and treatment reduces the adverse effects of disease. Typically medicine 6 are either Introduced through the food, or a drug or chemical Is introduced directly into the pond 
water. These methods are effective in the control of bacterial protozoan and fungal diseases. No treatment other than destruction of the infected population has been developed for IHN.

Saunders et al.(1972) discuss various methods of water treatment which may be useful in the control of infectious agents. Mortalities were reduced by ultraviolet irradiation, chlorination, and microfloc sand filtration.

Development of vaccines for control of infectious diseases has been slow, primarily because of US Food and Drug Administration regulations relating to veterinary pharmaceuticals and because of the effectiveness of chemical treatment and environmental management (Antipa and Croy 1379 ).

Generally data on specific outbreaks at specific hatcheries are not available in the published literature. Thus, it is difficult to evaluate the impact of diseases upon the productivity of these facilities. Gould and Wedemeyer (undated) suggest that, although disease may play a role in the overall decline on middle Columbia Kiver basin anadromous fish runs, this role is not a particularly significant one. They note, however, that stress from a variety of factors can be responsible for low levels of diseases, which in turn may be one of the several subtle factors contributing to the d e cline. 


\section{I . Methods and materials}

\section{A. Field program}

Specific methods and procedures were required to satisfy the objectives of this project. Examples Include methods of calculating water quantity, water quality, condition of facilities, and

financial profiles for each station. The methods used to obtain the required data are as follows.

\section{Water quantity}

Each agency participating in this study was asked to furnish stream flow data which were incorporated into the water quality file. Any such data was incorporated into the water quantity f i l e .

Many of the hatcheries obtain water from streams that do not have a substantial stream flow data base. In these situations, where practical, an on-site measurement or estimate of stream flow wae made under the supervision of a licensed professional engineer. The preferred method of flow measurement was by current meter or weir. An acceptable technique involved velocity measurements utilizing drogues, or flow calculations using standard hydraulic equations.

Water withdrawal and use volumes were obtained for each hatchery that maintains this type of record. When practical, onsite measurements or estimates of water withdrawal and use were made for each significant water source at each hatchery. Where possible, withdrawal measurements were made at the intake using a current meter or weir. Pumped water flows were estimated using manufacturers' pump curves, running time curves, or flow meters, weirs, or volumetric measurements. 


\section{Water quality}

Each agency participating in the study was asked to furnish water characteristic data not included in the STORET file.

On-site measurements for selected water characteristics were made for each significant water source at each hatchery. Duplicategrab samples were taken at the hatchery where posible. Dissolved oxygen samples were taken at the inlet and outlet of hatchery aeration facilities, where applicable. All water sampling and analyses were performed under the supervision of a licensed professional engineer and In accordance with the procedures described in Standard Methods, 15 th Edition. Water characteristics collected on site were entered into the data archive developed for this project. (2.4 and 2.4.1) 
TABLE 2

ON-SITE WATER CHARACTERISTICS

Water characteristic

( for all sources)

Dissolved oxygen

$\mathrm{PH}$

Total alkalinity (mg/1 CO3)

Total hardness (mg/l CaCo3)

Temperature (F and C>

(for groundwater sources only)

Barometric pressure $(\mathrm{mm} \mathrm{Hg})$

Differential dissolved gas pressure $(\mathrm{mm} \mathrm{Hg})$
AND METHODS OF ANALYSIS

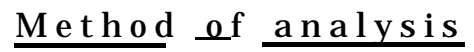

Modified Winkler

Standardized glass electrode

Acid titration

EDTA titration

Calibrated temperature probe

Calibrated aneroid barometer

D'Aoust and Clark 
3. Hatchery facilities

Compilation of data on existing facilities required obtaining site, building, and facility drawings from the fishery agencies. Information obtained from these drawings was supplemented with visual observations at the facilities and conversations with persons knowledgeable about the facilities ( 2.6 and 3.1$)$.

Building materiels and conditions of buildings were coded as follow :

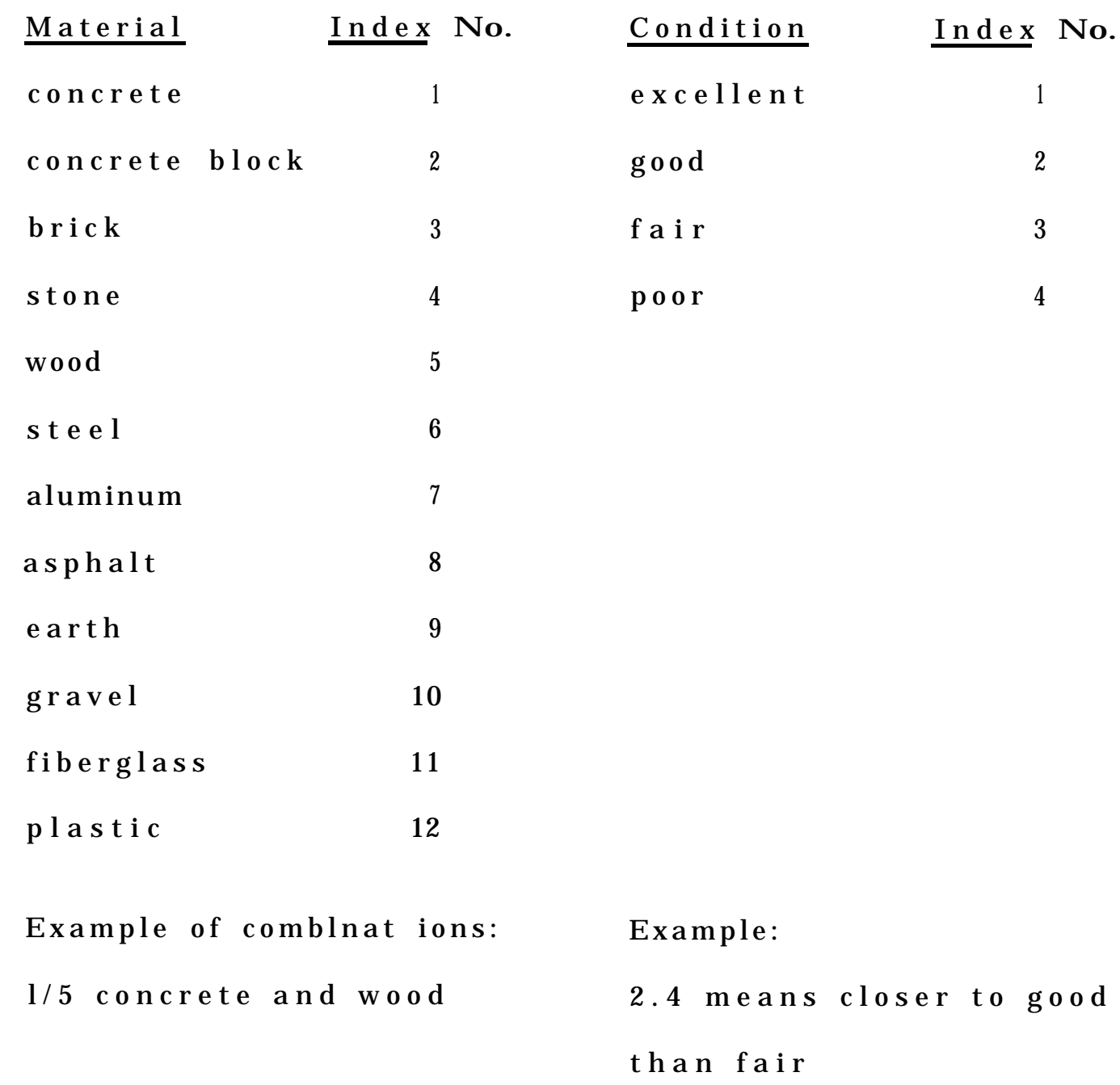




\section{Financial profile fereach station}

A financial profile was prepared for each site, using the Financial Profile Form I-16. The financial profile is Intended to show operating expenditures.

Financial data were obtained from the respective operating agencies for fiscal years 1981, 1982, 1983. This information was reviewed and some changes were made $i$ the financial categories. In most Instances satellite ponds and rearing stations were not budgeted individually but were included with the primary hatchery. These instances are noted. Because there is no uniform system of cost allocation and each agency aggregates costs according to Its unique system of cost categories, the data are presented in the most general system available, and are annotated where cost allocation may differ from the standard allocation. To provide comparable results no agency overhead was included in any costs, but personnel benefits were included as a personnel cost.

For several Idaho hatcheries, feed is purchased by Idaho Power, while the hatcheries are operated by Idaho Fish and Game. The two agencies use different fiscal years. Since the feed costs are relatively constant, the listed operating costs reasonably reflect the actual costs but may vary from true annualized costs.

We reported actual hatchery operating costs, excluding general management and overhead costs. We asked that the agency-supplied figures represent salaries and costs associated only with personnel regularly assigned to a hatchery site. Although there are some differences between agencies in assignments of managemeut and 
overhead costs, we believe that the data reflect, in the case of each agency, the actual operating costs for each hatchery. Each agency was provided with a copy of the allocated costs for each hatchery, and comments and notations were incorporated Into the final draft.

\section{Standard calculation to achieve full production}

Full production is estimated with three procedures. These are: 1.) the "flow method" (weight of fish per gallons per minute (CPM) of Inflow), 2.) the "density method (weight of fish per cubic foot of pond volume), and 3). a method derived from agency production goals.

The formula for the "flow" estimation procedure was:

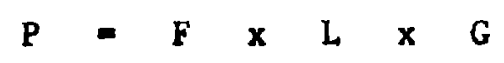

where:

$$
\begin{aligned}
& \text { P - production in pounds per GPM } \\
& \text { F - loadfactor to convert altitude and water } \\
& \text { temperature into fish production values (see } \\
& \text { Bell } 1973, \text { Piper et al. 1982) } \\
& \text { L } \quad \text { length of fish in Inches } \\
& \text { G - gallons per minute of water inflow }
\end{aligned}
$$

The load factors to be used are derived from Bell (1973) and Piper et al. (1982) and are a function of pond temperatures and altitude.

The formula for the "density" estimation procedure is after the formula in Piper et al. (1982), and follows: 


$$
\mathrm{D} \quad=\begin{array}{lllll}
.5 & \mathrm{X} & \mathrm{L} & \mathrm{X} & \mathrm{V}
\end{array}
$$

where:

D - density in pounds of fish per cubic foot

L - length of fish in inches

v - volume of rearing space in cubic feet

For the purposes of this project, a uniform procedure was used to estimate fish length (Piperet al. 1982). For each species, the length at release was determined by estimating the average fish pet pound released at a facility, then converting that estimate to a length eet imateby use of tables in Piperetal. (1982) most closely approximating the species condition factor rounded to the nearest 5 $\mathrm{x} 10 \quad(\mathrm{e} \times \mathrm{p}-5)$.

Further examination of the data revealed a third method, and possibly the best method, derived from agency production goal statements. The formula for this method is:

$$
\mathrm{P}-\mathrm{D} \times \mathrm{V}
$$

where:

$$
\begin{aligned}
& \text { P - productionin pounds per cubic foot } \\
& \text { D - density in pounds per cubic foot; densities } \\
& \text { used were. } 8 \text { and } 2 \text { pounds per cubic foot which } \\
& \text { provides an appropriate and reasonable range of } \\
& \text { rearing densities } \\
& \text { v - volume of rearing ponds in cubic feet }
\end{aligned}
$$

The density range of from .8 to 2 pounds per cubic foot provides a usable range of production density goals. This range is based upon agency production goal statements (Lower Snake River 
Fish and Wildlife Compensation Plan 1983) of 8 pounds per cubic foot (Washington Department of Fisheries) and 2 pounds per cubic foot (Idaho Department of Fish and Came and US Fish and Wildlife Service). The density range of 8 to 2 pounds per cubic foot provides a usable range of production density goals. Actual production estimates (Table 3 ) are based upon pounds released and are designated as pounds pet cubic foot per year.

This range is based upon agency production goal statements (Lower Snake Kiver Fish and Wildlife Compensation Plan 1983) of .8 pounds per cubic foot (Washington Department of Fisheries) and 2 pounds per cubic foot (Idaho Department of Fish and Came and US Fish and Wildlife Service). The density range of .8 to 2 pounds per cubic foot provides a usable range of production density goals. Actual production estimates (Table 3 ) are based upon pounds released and are designated as pounds per cubic foot per year.

Production at the Columbia Kiver Basin facilities examined in this project ranged from 2.36 pounds per cubic foot at Abernathy National Fish Hatchery to 0.02 pounds per cubic foot at the Kingold Steelhead rearing facility. During the three year period examined, an average of 6.1 million pounds of anadromous salmonids were released from Columbia Basin facilities with a rearing volume of 33.5 Million cubic feet. This represents an average annul production at release of U.18 pounds per cubic foot.

The reasons for the great differences in densities at release include the limitations imposed by water quantity and quality, differences in agency policy on rearing density, density reductions due to disease, predation or other natural mortality factors, and limits to available eggs (specifically spring and summer chinook 
stocks). In a number of cases non-endemic stocks were subjected to rearing conditions such as disease abd high temperatures that resulted in low production. Disease resulted in the total or partial loss of several years of production at several of the facilities. Mortality among adult spring chinook was extremely high at all facilities, resulting In a $30 \%$ to $50 \%$ mortality prior to spawning, and significantly reducing spring chinook smolt production.

In order to make the full production estimation procedure as uniform as possible, a "full production/cost of modifications" form (Table 3 ) was developed that summarizes for each station fishery and facilities data, estimates theoretical production by the methods described,designates productionlimiting factors, and estimates with comments construction coats and increases In operating costs. 
TABLE 3

FULL PRODUCTION/FACILITY MODIFICATIOINS/COSTS

HATCHERY

1. ACTUAL PKODUCTION:

\section{LOCATION CODE}

DATE

NAME

\begin{tabular}{l}
\multicolumn{2}{c}{ SPECIES } \\
SP. CHINOOK \\
SP.CHINNOK \\
F. CHINOOK \\
COHO \\
S. STHD \\
W. STHD \\
SK. CUT. \\
RES. TROUT
\end{tabular}

TOTAL

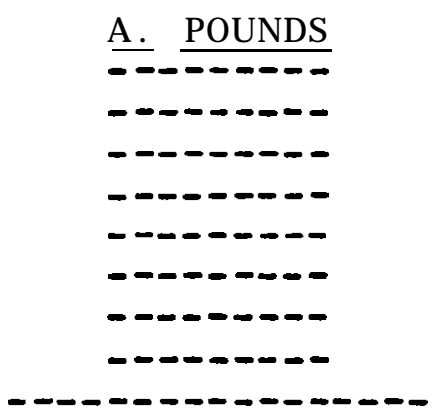

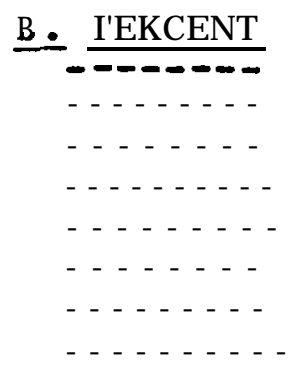

2. THEOKETICAL PRODUCTION-bas ed on existing facilities and:

- DENSITY FORMULA

- FLOW FORMULA

- AGENCY CRITERIA RANGE AND
$(05 \times \mathrm{L} \times \mathrm{VOL})=$.

( $\left.\begin{array}{lllll}\mathrm{F} & \mathrm{X} & \mathrm{L} & \mathrm{X} & \mathrm{GPH}\end{array}\right)$

(. $8 \mathrm{X}$ VOL)

$(2 \times$ VOL $)=$

3. FACTORS CONTROLLING PKODUCTION

A. POND VOLUME

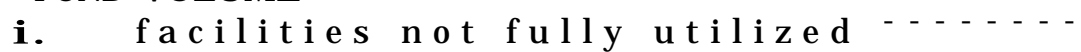

il. new facilities

B. WATER

i. increased amt. available

i i. reuse

i i . enhance $\overline{\text { quality }}$

- temperature

- a eration

- treatment- $\overline{6 \text { recir }}$.

c.FISH Biomass

I. Increase density

i i. decrease density

i i i. Increase feed

iv. rearing density $-1 \mathrm{~b} / \mathrm{CP}$

$-\mathrm{lb} / \mathrm{CPr} 4$

MODIFICATION COMMENTS:

4. ESTIMATED INCREASED PRODUCTION (TOTAL):

5. ESTIMATED CONSTRUCTION COSTS:

6 ESTIMATED INCREASE IN OPERATIONS COSTS.

* Volume of currently used ponds

() Volume of total available pond space 


\section{Summary of facilities and costs to achievefull}

propagation potential

Data concerning the minimum available amount of water and its characteristics were recorded for each propagation site, based on available historical data, use restrictions, and on-site investigation (Table 3). The amount of unused water was determined by on-site investigation, available records, and communication with the hatchery operators.

Where there is potential for expansion, the estimates of capital and operating costs (in terms of 1984 dollars) were determined by relating the original construction costs (if available) and operating costs (corrected to 1984 dollars) to the pounds of fish produced.

Where the costs for the original capital constructions were not available, the replacement value of the facility was determlned from costs of similar facilities and that figure used to calculate the price per pound.

$(3.1$ and 3.2 )

The additional pounds of fish the expansion could produce were multiplied by the price per pound, for capital and operating costs, to obtain the total cost of the expansion.

\section{Station personnel by category}

Station staffing is reported to the nearest man-month. In general, staffing is recorded for primary hatcheries only, not ponds and rearing stations, although non-agency personnel are listed for satellite locations. 


\section{B. Data entry}

1. Data forms

Collecting and organizating information about fish culture stations in the Columbia River basin required data forma for recording information about operations at each station and about the condition of the physical facilities. Forms previously developed were reviewed.and in some cases modified: new information requests were added to some forms, and some requests that were trivial, unnecessary, or duplicative were deleted. The modified forms were submitted and approved by BPA.

The original data summary and comment summary forms were modified to make them more useful, especially for persons who do not need the detailed data. The hatchery summary form was expanded to include the summary comments form. A summary of important Information about each hatchery is thereby included in one section. There is no change in the upper portion of the hatchery summary form, but the synopsis section of the lower portion is combined with the summary comments form. The information requested at the bottom of the hatchery summary form under the heading "Facility and Operating Synopsis"Includes the following:

1. Site description.

2. Description, condition, and adequacy of main buildings and facilities.

3. Source, amount, and quality of water.

4. Species raised in hatchery.

5. Diseases and how serious they are.

6. Interrelationship with other hatcheries.

7. Other significant comments.

Following the preceding section is a discussion of opportunities for increased product ion, taken from the summary comments form. 


\section{Computer program}

The data base management system MicroRIM, developed for microcomputers, was used on IBM-compatible micro-computers. The original program, RIM (Relational Information Management system), was developed in 1979 for NASA by Wayne J. Erickson and Dennis L. Comfort, who, at that time,were with the Boeing Computer Service Company. RIM was originally written for main-frame computers. Erickson left Boeing and joined the staff of the University of Washington Academic Computer Center (ACC) and further refined RIM for main-frame computers. RIM is available from the ACC for use on many main-frame computers. Subsequently, Erickson left the ACC to form MicroRIM, Inc., where he developed MicroRIM for use on microcomputers.

RIM and MicroRIM were written expressly for engineers and scientiata, whose requirements are considerably different from those of business. The program is f lexlble and is capable of handling both numeric (Integer and real) and text (string) data.

MicroRIM is capable of handling over 50 fields (numeric or text) per record. The maximum length of a text field is 1,500 characters, which is more than adequate. Data stored by MicroRIM may be manipulated and compared without modifying the original entries. An additional advantage of MicroRIM is that the data can be readily retrieved and printed in a desired format. Data entered into a micro-computer using MicroRIM are readily available for use on a main-frame computer using the program RIM. 


\section{Method_of data entry}

Using MicroRIM, masks were developed so the data collected In the field could be entered directly into the data base with only minimal manipulation of the data prior to entry.

Because of the large number of entries per hatchery (over $1,500)$ the data was divided into nine different files as follows:

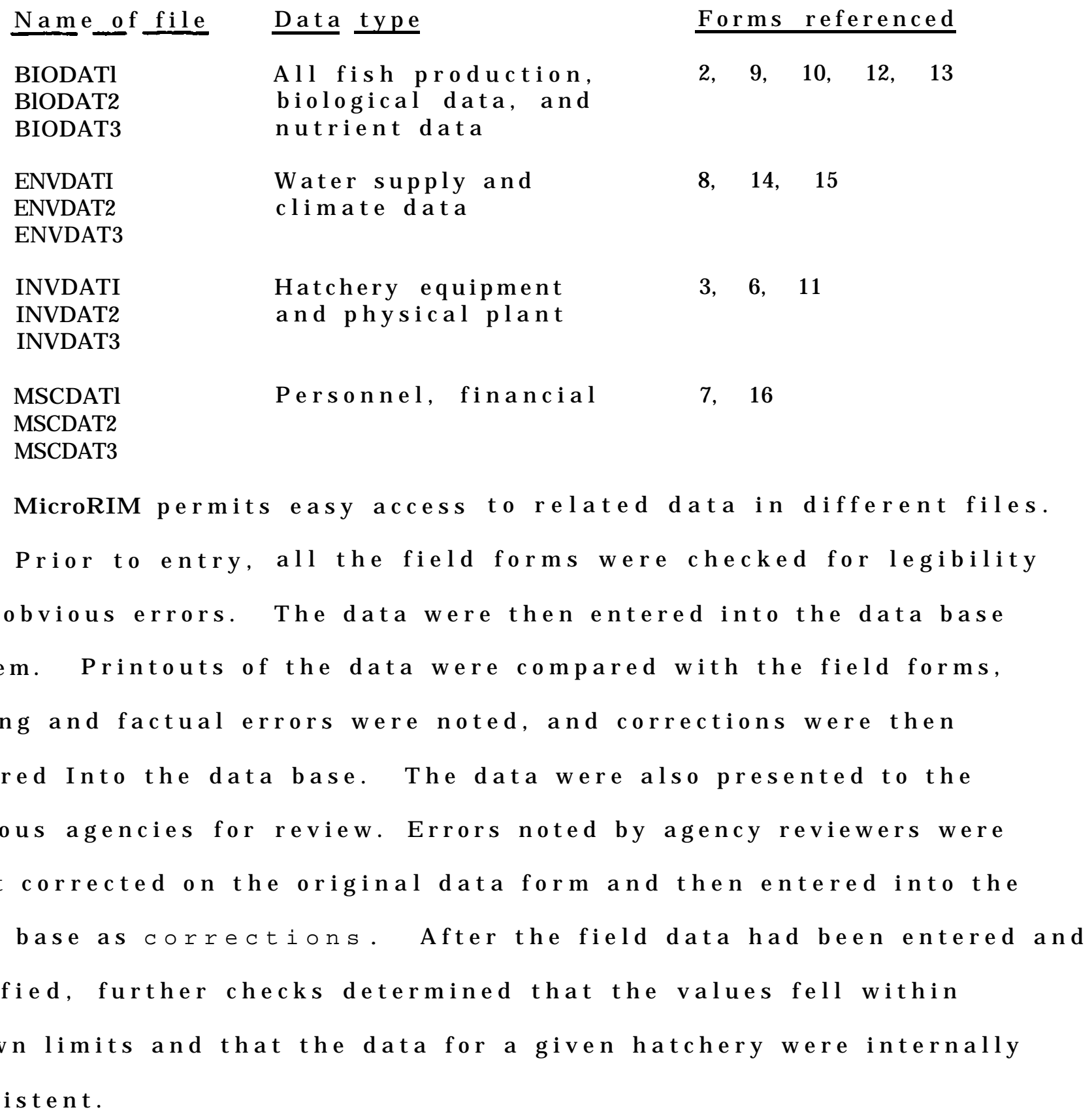


IV. Project plan

The plan for satisfying the terms of the contract was arranged into 12 units as follows:

Unit 1. Identify data in central repositories.

Unit 2. Kecord data from central repositories.

Unit 3. Test field procedures.

Unit 4. Acquire data from Kegion IV, Snake River system.

Unit 5. Acquire data from Region III, Columbia River above the Snake Kiver confluence.

Unit 6. Acquire data from Region II, Columbia Kiver between Bonneville Dam and the Snake River.

Unit 7. Acquire data from Region I, Columbia River below Bonneville Dam.

Unit 8. Kecord data in data archive system.

Unit 9. Analyze and summarize data.

Unit 10. Provide data appendices and data archive.

Unit il. Prepare facility site plans.

Unit 12. Prepare final report.

Unit 1. Identify data in central repositories

This unit identified data available from fishery agency central repositories for recording on the forms described under "*Methods and materials." The work was accomplished through a subcontract with Richard Noble and Roy Wahle. Wahle identified Information available from the US Fish and Wildlife Service, the Oregon Department of Fish and Wildlife, and the Idaho Department of Fish and Came. The unit partially satisfies requirements of KFP tasks 2.4 through 3.4 . 
Unit 2. Record data from central repositories

Gala personnel will acquire at the central repositories of the various fishery agencies Information identified in Task 1.0 which is available at these repositories. Computer printouts will be obtained where available and in other instances it will be necessary to make copies of data. At Caiaheadquarters, this Information will be entered into the data archives.

\section{$\underline{\mathrm{U} \quad \mathrm{n}}$ i Ttest $\underline{\text { Tield procedures }}$}

Before beginning full-scale field operations, Gala personnel tested the procedure6 for obtaining and recording the Information required under the terms of the contract at the Washington State Department of Fisheries hatchery on the Columbia River.

Personnel reeponsible for collecting or analyzing data present for this test.

$\underline{\mathrm{Uni}}$ t 4. Acquire data from $\underline{\text { Region }} \underline{\mathrm{IV}}$

Information required under the terms of the BPA contract and not available at agency central repositories will be obtained from actual on-site visits to the various hatcheries listed in Table 1. Initial contact was made by telephone with each hatchery manager at least 24 hours prior to the on-site visit. when each team arrlved at a given site, the hatchery manager was appraised of the project objective and the purpose In visiting the hatchery.

The engineer and biologist were responsibile for specific data and usually collected those data independently. However, when needed for such tasks as flow measurements and water sampling, the team worked together. Following completion of data collection, the team reviewed the information with the hatchery 
manager to clarify any anomalies or discrepancies. Analyses of the water samples were completed as soon as feasible. A check list for each hatchery visit is provided in Table 4 . 
TABLE 4

\section{SITE VISIT PROTOCOL CHECK LIST}

A. Call hatchery manager at least 24 hours before visit.

B. Biologist and engineer
Introduce themselves.
Explain project and data collection efforts.
_ Tour facility with manager and/or hatchery personnel.

c. Engineer completes the following forms:

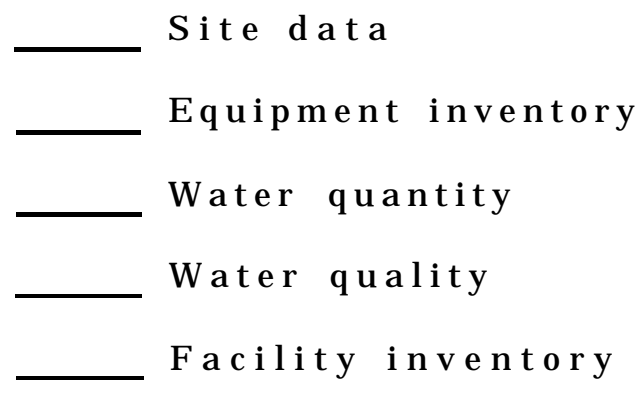

D. Biologist completes the following forms:

$$
\begin{aligned}
& \Psi \text { Staffing summary } \\
& \text { Feed supply data } \\
& \text { Disease data } \\
& \text { Fish handling data }
\end{aligned}
$$

E. Engineer and biologist together

$\perp_{-}$Prepare any summary comments
Review data with hatchery manager
Complete water analyses
Review and complete data forms


The hatcheries of the Columbia River basin were grouped into four reglons as listed in Table l. Information required by keP

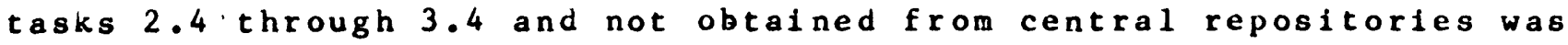
obtained at the hatcheries.

Because of the harsher weather conditions to be expected in Region IV (Snake River system) during the winter, field operations started there. Two teams (each consisting of an engineer and a biologist) collected data from the facilities in the region. Standard operating procedures, revised after test operations at the Cowlitz River Salmon hatchery, were followed in obtaining information. Information was recorded on BPA-approved forms.

Units 5-7. Acquire data from Regions I-III

Following completion of data collection in Region IV, survey teams moved operations to the Columbia River and tributaries other than the Snake River. The procedure for collecting information in Region IV was repeated for the hatcheries in Regions I-III.

Unit 8. Record data 1n data archive system

All data forms were filed at Gala headquarters in Seattle, checked for accuracy, and then recorded in the data archive system as described in the section on Methods and materials. This unit satisfies the requirements of RFP 2.11 .

\section{Unit 9. Analyze and summarize data}

The RFP requires some analysis and summary of the information recorded from flshery agency headquarters and from hatcheries. These requirements were grouped into four sub-units as follows: 
$\underline{\text { Sub-unit }} \underline{\text { Develop }}$ an operating financial profile for

e ach station for 1981-1983

Data for this Sub-unit were obtained from agency report6 and adapted to the financial profile form. Categories included cost 6 for personnel, fish food, transportation, supplies, equipment, energy, capital improvements, and total annual budget. The procedures for developing. the financial profile are described in "Method6 and materials." This sub-unit satisfied the requirement6 of KFP task 2.1

\section{Sub-unit 2. Estimate - costs to achievefull propagation} $\underline{\text { potential }}$

The capital and operating cost 6 required to achieve full propagation potential were estimated after data concerning the Original cost Of facilities and Operating costs were obtained. These costs were evaluated according to the procedure described in the section on $\underline{\text { Methods }}$ and materials. This sub-unit satisfies the requirements of RFP task 3.1 .

\section{Sub-unit 3. Record current production level by species} $\underline{\text { and estimate full propagation level }}$

Current and estimated full production and materials were recorded in accordance with the procedure6 described in the "Methods" section. This sub-unit satisfies the requirements of KYP task 3.1 .

Sub-unit 4. Summarize for each station current

personnel by category

Personnel information personnel was recorded during visits to hatchery facilities and checked against agency records. This subunit fulfill6 the requirements of RFP task 3.4. Station staffign is 
reported to the nearest man-month. In general, staffing is recorded for primary hatcheries only, not ponds and rearing stations, although non-agency personnel are listed for satellite locations. Unit 10.Provide data appendices and data a $\underline{\text { rchive }}$ Fourdata appendices (A-D, one of each region), contain all information about each hatchery. Data from each facility listed in Table 1 were archived as described in the section on Methods and $\underline{\text { materials }}$ and are recorded on floppy disks as Appendix E. This unit fulfills requirements of RFP tasks 4.0 and 5.0 .

Two requirement 6 of the RFP do not readily fit into these units. These are:

\section{(1) List potential hatchery sites}

Through discussion with the BPA technical representative, it was decided to limit the list of potential hatchery sites to those provided by the fishery agencies. This Information was obtained by mail, telephone, or personal visit. Appendix A is a summary of information about these sites and satisfies the requirements of RFP task 2.10 .

(2) Report technical d oc $\underline{\text { unents }}$

Technical documents cited in the report relating to fishrearing operations at each hatchery are included In the “Literature cited" section. Technical document6 not cited are listed as Additional Technical Reports. This Unit satisfies requirement 6 of KFP tasks 1.0 and 1.3 . 


\section{Unit 11. Prepare facility site plans}

Site plans of facilities were prepared from plans submitted by state and federal agencies and PUD's and modified as a result of visits to facilities and agency review (Appendix I).

\section{$\underline{\text { Unit }} 12 \ldots$ Prepare final report}

This draft report is being submitted to BPA for comment. The final report will incorporate BPA suggestions and suggestions received from fishery agencies. 


\section{LITERATURE CITED}

ACARA, A. 11.1477. The Meadow Creek spawning channel. Fisheries and Marine Service Technical Keport No. (744). Akepshire, Jr., B. M., I. J. Tinsley, and K. K. Lowry. 1983 . Effect of temperatureon the chemical conposition of pink salmon (Oncorhynchus gorbuscha) muscle. Aquaculture $32: 295-301$.

Akiyama, T., T. Murai, and T. Nose. 1982. Effects of various dietary carbohydrates on growth, feed efficiency, and body composition of chum salmon fry. Bulletin of National

Research Institute of Aquaculture, Japan 3:75-80

Akiyama, T., T. Murai, Y. Hirasawa, and T. Nose. 1984.

Supplementation of various meals to fish meal diet for chum salmon fry. A qu a c u l t u r e $37: 217-222$.

American Public Healtn Association, American Water Works

Association and Water Pollution Control Federation, 1961.

Standard methods for the analysis of water and wastewater. 15 th edition. New York, USA.

Antipa, K. C., and T.K. Croy. 197Y. Fish vaccine development and testing. Progressive Fish Culturist 41(1):4b-47.

B a i l e y, J. E., S. D. Rice, J. J. Pella, a n d S. C. T a y l o r.

1980. Effects of seeding density of pink salmon ( Oncorhynchus gorbuscha) eggs on water chemistry, fry characteristics and fry survival in gravel incubators. Fisheries Bulletin $78(3): 64$ Y - 658 . 
Cans, K. A. 1967. Differences in performance of naturally and artificially propagated sockeye salmon migrant fry as measured with swimming and predation rests. Journal of the fisheries Research board of Canada 24:1,117-1, 153 .

B a ms, K. A., and K. S. Simpson. 1976. Substrate incubators workshop-1976. Keport on current state-of-the-art. Canada Fisheries and Elarine Service, Technical Keport (689).

Barry, W. Nov. 11, 1967. A toxonomic investigation of the vegetation at the Spokane Trout Hatchery and Saint George's School. Conzaga University, Spokane, Washington, USA.

B a su, S. P. 1959. Active respiration of fish in relation to ambient concentrations of oxygen and carbon dioxide. Journal of the Fisheries Research Board of Canada 16(2): $175-212$.

B a uer, E. P. 1982 . The photoperiod control of coho salmon smoltification. Aquaculture 28: 105-1 11.

Beamish, F. W. il. 1964 . Influence of starvation on standard and routine oxygen consumption. Transactions of the America Fisheries Society $93: 103-107$.

B e a mish, F. W. H., and L. M. Dickie. 1967.11 etabolism and biological production in fish. Pages 215-242_in S. D. Gerking, editor. The biological basis of freshwater fish production. Blackwell Scientific Publications, Oxford and Edinburgh, England. 
Becker, C. D. and M. D. Yujihara. 1978. The bacterial pathogen (Flexibactor columnaris ) and its epizootiology among Columbia River fish: a review and synthesis. American Fisheries Society Monograph No. 2 .

Bell, M. C1973.Fisheries handbook of engineering requirements and biological criteria. United States Army Engineering Division, Corps of Engineers, Portland, Oregon, USA.

Bilton, M. T.1978. Keturns of adult coho salmon in relation to mean size and time at release of juveniles. Fisheries Marine Service Technical Keport ( 832 ).

Bilton, M. T. 1980 . Keturns of adult coho salmon in relation to mean size and time at release of juveniles to the catch and the escapement. Canadian Technical Keport of Fisheries and Aquatic Sciences (941).

bilton, H. T. 1981 . Experimental releases of coho salmon in British Columbia. Pages $305-324$ in J. Thorpe, editor. Salmon Ranching. Academic Press, London, England.

Bilton, M. T.1983. Keturns of chinook salmon in relation to juvenile size at release. Canadian Technical Keport of Fisheries and Aquatic Sciences (1245).

Bilton, M. T., D. F. Alderdice, and J. T. Schnute. 1982 . Influence of time and size at release of juvenile coho salmon (Oncorhynchus kisutch) on returns at maturity. Canadian Technical Report of Fisheries and Aquatic Sciences. 
Bilton, M. T., and D. W. Jenkinson. 1980 a. Keturn to the fishery and escapementof adult coho salmon from accelerated and normally reared juveniles. Canadian Technical Report of Fisheries and Aquatic Sciences (925).

Bilton, H. T., and D. W. Jenkinson. 1982 b. Keturn to the fishery and escapement of adult coho salmon from accelerated juveniles released in the fall of 1974 . Canadian Technical Keport of Fisheries and Aquatic Sciences (943).

blaxter, J. M. S. 1975 . Reared and wildfish--how do they compare? Tenth European Symposium on Marine Biology. Ostend,Belgium. September 17-23, 1975. 1:11-26.

Bouck, G. K. 1982. Gasometer: an inexpensive device for continuous monitoring of dissolved gasses in supersaturation. Transactions of the American Fisheries Society $111: 505-516$.

Boydstun, L. B., and J. S. llopelain.1977. Cagerearing of steelhead rainbow trout in a freshwater impoundment. Progressive Fish Culturist $39(2): 70-75$.

Brannon, E., C. Feldmann, and L. Donaldson. 1982. University of Washington zero-age coho salmon smolt production. Aquaculture 28:1Y5-200.

Brett, J. K. 1952 . Temperature tolerance in young Pacific salmon genus (Oncorhynchus). Journal of the Fisheries Research Board of Canada Y (6 ): 265-314. 
Brett, J. K. 1976. Feeding metabolic rates of young sockeye salmon (Oncorhynchus nerka) in relationto ration level and temperature. Fisheries Marine Service Research Development Technical Keport (675).

Brett, J. K. 1979. Environmental factors and growth. Pages 599-675 in W. S. Har, D. J. Kandall, and J. R. Brett editors. Fish Physiology, Vol. 8. Academic Press, New York, San Francisco and London.

Brett, J. K., and J. M. Blackburn. 1981 . Oxygen requirements for growth of young coho (Oncorhynchus kisutch) and sockeye ( 0 . Nerka) salmon at 15 C. Canadian Journal of Fisheries and Aquatic Science 38:399-404

Brett, J.K., W. Griffiden, and A. Solmie.1978. The 1Y77 crop of salmon reared on the Pacific Biological Station experimental fishfarm. Fisheries and Marine Service Technical d e port ( 845$)$.

Bronley, P. J., and C. Smart. 1981. The effects of the major food categories on growth, composition and food conversion in rainbow trout (Salmogairdneri Richardson)

Aquaculture 23:325-336.

bureau of Commerical Fisheries. 1969-1971. Da ta report:

Columbia Kiver coho salmon hatchery contribution study: 1967-69 sampling season(s). Biological Laboratory, Seattle, Washington, USA.

Burrows, K. E. 1969 . The influence of fingerling quality on adult salmon survival. Transactions of the American Fisheries Society $98: 777-784$ 
Burrows, K. E., and B. D. Combs. 1968. Controlled environments for salmon propagation. Progressive Fish Culturist $30: 65-80$

Buterbaug, C. L., and M. Willoughby. 1967. A feeding guide for brook, brown and rainbow trout. Progressive Fish Culturist 29:210-215.

Carey and Kramer. July 1966 . D worshak Dam and Keservoir North Fork Clearwater River, Idaho. United States Corps of Engineers,Fish Hatchery Design Memorandum 14.1, Walla Walla District, Washington, USA.

Clarke, W. C., and J. Blackburn. 1978. Seawater challenge tests performed on hatchery stocks of chinook and coho salmon in 1977. Fisheries Marine Service Technical Report ( 761$)$.

Clarke, W. C., D. A. Higgs, J. K. Plarkert, J. E. Shelbourn, and A. J. Castledine. 1982 . Effects of varying dietary protein: lipid ratios on growth and body composition of coho salmon fry (Oncorhynchuskisutch) reared at different temperatures. Canadian Data Keport Fisheries Aquatic Sciences No. 373. Colt, J., and H. Westers. 1982. Production of gas supersaturation by aeration. Transactions of the American Fisheries Society 111:342-36U.

Corey, P. D., D. A. Leith, and M. J. English. 1983. A growth model for coho salmon including effects of varying ration allotments and temperature. Aquaculture 30: 125-143. 
D'Aoust, B. C., and M. R. Clark. 1980. Analysis of supersaturated air in natural waters in reservoirs. Transactions of the American Fisheries Society 109: 708-724.

Dawley, E. M., et al. January 1984. Migration characteristics and survival of juvenile salmonids entering the Columbia River estuary during 1982. Bonneville Power hdministrat ion. Portland, Oregon, USA.

Downey, P. C., and C. W. Klontz. 1978. A systems approach to hatchery production, or everything you wanted to know about fish but were afraid to ask your computer.

Proceedings of the Northwest Fish Culture Conference.

Duff, D. C. B., and J. B. Stewart. 1933 . studies on furunculosis of fish in British Columbia. Canadian Contributions in Biology and Fisheries 8:103-122.

Dunlin, M. P., T. Huddleston, K. T. Larson, and G. W. Klontz. 1976. Enteric redmouth disease. University of Idaho College of Forestry, Wildlife and Range Sciences. Bulletin Number 8.

Durkin, 11. T., and C. W. Sims. 1975. Migrations of juvcni le coho salmon (Oncorhynchus kisutch) into the Columbia River estuary, 1966-1971. National Marine Fisheries Service Northwest Fisheries Center. Unpublished manuscript.

Eicher, C. J., Jr. 1946. Lethal alkalinity for trout in waters of low salt content. Journal of Wildlife Management 10(1): $82-85$.

Ejike, C., and C. B. Schreck. 1980. Stress and social hierarchy rank in coho salmon. Transactions of the American Fisheries 
Society $109: 423-426$.

Eklund, M. W., M. E. Peterson, F. T. Poysky, L. W. Peck, and

J. F.Conrad. 1982. Botulism in juvenile coho salmon

(Oncorhynchuskisutch) in the United States. Aquaculture $27: 1-11$.

Ekkuitm J. W.1969. The oxygen requirements of chinook salmon.

Progressive Fish Culturist 31(2):67-73.

Ewing, K. D., H. J. Pribble, S. L. Johnson, C. A. Fustish, J.

Diamond, and J. A. Lichatowich. 1980. Influence of size, growth rate, and photoperiod of cyclic changes ingill (Na + R0-ATPase activity in chinook salmon (Oncorhynchus

tshawytscha). Canadian Journal of Fisheries and Aquatic Sciences $37: 600-\mathrm{b} 05$.

Fagerlund, U. M. M., D. A. Higgs, J. K. McBride, M. D.

Ylotnikoff, and B. S. Dosanjh. 1980. The potential for using the anabolic hormones $17 \propto$-Methyl-testosterone and/or $3,5,3^{\prime}$ triiodo-L-thyronine in the fresh water rearing of coho salmon (Oncorhynchus kisutch) and the effects on subsequent saltwater performance. Canadian Journal of Zoology. 58: $1424-1432$.

Fagerlund, U. H. M., D. A. Higgs, J. K. McBride, 11. D. Plotnikoff, and B. S. Dosanjh, and J. K. Markert. 1983 . Implications of varying dietary protein, lipid and $17 \propto-$ methyltestosterone content on growth and utilization of protein and energy in juvenile coho salmon. Aquaculture $30: 109-124$. 
Yagerlund, U. H. M., J. K. McBride, B. S. Dosanjh, E. T. Stone, and F. K Sandercock. 1983. Influence of culture density on juvenile coho salmon production and ocean survival. Smolt releases in 1979 and 1980 from Capilano hatchery. Canadian Fisheries and Aquatic Science Technical Keport (1229).

Fagerlund, U. H. M., J. R. McBride, and E. T. Stone. 1979. A test of $17-$ methyltestosteron as a growth promoter in a coho salmon hatchery. Transactions of the American Fisheries Society $108: 467-472$.

Fagerlund, U. M. M., 1. McCal lum, D. A. Higgs, J. K. McBride, M. D. Ylotnikoff, and B. S. Dosanjh. 1984 Diet composition as a factor in the anabolic efficacy of $3,5,3$ '-triiodo-Lthyronine administered orally to steelhead trout gairdneri). Aquaculture 36:49-59.

Fenderson, O. C., and M. K. Carpenter. 1971. Effects of crowding on the behavior of juvenile hatchery and wild landlocked Atlantic salmon (Snlmosalar L.). Animal Behavior $19: 439-447$.

Finlayson, B. J., and K. M. Verrue.1982. Toxici ties of copper, zinc, and cadmium mixtures to juvenile chinook salmon. Transactions of the American Fisheries Society 111 : $645-650$.

Fish Farm Catalogue. Nile Spring Natural Kearing Area ( report). Washington. 
Foda, A., and T. R. Henderson. 1977. Effect of water temperature on rate of embryonic development, growth and survival of Atlantic salmon (SaImosalar). C. M. 1977/M:31.

Kesource Branch, Fisheries and Marine Service, Department of Fisheries and Environment, Malifax, Nova Scotia, Canada.

Folmar, L. C., and W. W. Dickhoff. 1981. Evaluation of some physiologicaI parametersas predictive indices of smoltifiication. Aquaculture 23:309-324.

Folmar, L. C., W. W. Dickhoff, C. V. W. flahnken, and F. W. Waknitz. 1982. Stunting and Parr-reversion during smoltification of coho salmon (Oncorhynctlus sisutctr). Aquaculture $28: 91-104$.

Fowler, L. C. 1980. Starting diets for chinook salmon fry. Progressive Fish Culturist 42:165-1 6.

Fowler, L. C. March 1981. Tests of vegetable protein replacements and alternate ingredients in the Abernathy diet. Technology Transfer Series No. $81-1$, Uni ted States Department of the Interior United States Fish \& Wildlife Service. Abernathy Salmon Cultural Development Center, Longview, Washington, USA.

Yowler, L. C. 1981. Protein and energy relation of starting diets for chinook salmon fry. Progressive Fish Culturist 43:151-153. Olympia, Washington, USA. 
Fouler, L. C., and J. L. Banks. April 1980. Survival rates of three sizes of hatchery reared fall chinook salmon, United State Department of the Interior, Technical Transfer Series No. 801, , United States Fish Wildlife Service. Abernathy Salmon Cultural Development Center, Longview, Washington USA. Fouler, L. G., K. E. Burrows, B. D. Combs, and J. L. banks. June 1980. The effect of size and time of release of fall chinook fingerlings on adult survival. United States Department of Interior,Technical Transfer Series No. 80-3, United States Fish and Wildlife Service. Abernatyhy Salmon Cultural Development Center, Longview, Washington USA.

Fouler, L. G. 1983 . Effect of dietary protein and energy on growth and survival of fall chinook salmon fry. Progressive Fish Culturist 45(2): $128-129$.

Fryer, J. L., J. S. Nelson, and R. L. Garrison. 1972 . Vibriosis in fish. Progressive Fish and Food Science 5:129-133. Fuss, M. J., and C. Johnson. 1982. Quality of chum salmon fry improved by incubationover artificial substrates. Progressive Fish Culturist 44(4): $170-172$.

Coff, T. K., and L. S. Forsyth. 1979. Production of Atlantic salmon smolts in one year without artificial heating of water. Mersey Hatchery, Nova Scotia. Fisheries Marine Service Technical Keport ( 841$)$.

Could, K. W., and C. A. Wedemeyer. Undated. The role of diseases in the decline of Columbia Kiver anadromous fish populations. United States Fish and Wildlife Service, National Fisheries Research Center, Seattle, Washington USA. 
Green, D. M., Jr. 1964. A comparison of stamina of brook trout from waild and domestic parents. Transcriptions of the American Fisheries Society Y3:96-1O.

Gunnes, K. 1976. Effect of size grading young Atlantic salmon ( $\underline{\text { Salmo salar }}$ ) on subsequent growth. Aquaculture 9:381-386. Haskell, D. C.1Y55. Weight of fish per cubic foot of water in hatchery troughs and ponds. Progressive Fish Culturist $17(3): 117-118$.

Memming, T. A., J. E. Mclnerney, and D. F. Alderdice. 1982 . Effect of temperature on initial feeding in alevins of chinook salmon (Oncorhynchus tshawytscha). Canadian Journal of Fisheries and Aquatic Science39:1,554-1,562.

Mickey, P. L., W. K. Hershberger, and J. N. Dong. 1979.

Hatching table for fisheries research. Progressive Fish Culturist $41(1): 25-26$.

Higgs, D. A., U. II. M. fagerlund, J. C. Eales, and J. K. McBride. 1982. Application of thyroid and steroid hormones as anabolic agents in fish culture. Comparative Biochemistry and Physiology $7313: 143-176$.

Higgs, D. A., U. M. PI. Fagerlund, J. K. McBride, M D. Plotnik off, B. S. Dosanjh, J. R. Markert, and J. Davidson. 1983. Protein quality of Altex canola meal for juvenile chinook salmon (Onorhynctlu tshawytscha) considering dietary protein and $3,5,3$ '-triiodo-L-thyronine content. Aquaculture 34:213-238. 
Higgs, D. A., J. K. McBride, F. R. Narkert, B. S. Dosanjh, 1-i. D. Ylotnikoff, and W. C. Clarke. 1982. Evaluation of tower aAnd candle rapeseed (canola) meal and Hronowske rapeseed protein concentrate as protein supplements in practical dry diets for juvenile chinook salmon (Oncorhynchus tshawytscha). Aquaculture 29:1-31.

Idaho State Department of Fish and Game, as follows:

Annual Reports (for all anadronous Columbia Kiver system hatcheries) $1981,1982 \& 1983$.

Annual Reports for Hagerman Fish Disease Laboratory (incl. NPDES info.) 1981. 1982, 1983.

Building Information reports for Eagle, Hyden Creek.

Inama, G. K., and A. F. Tautz. 1981. A simple growth model for salmonids in hatcheries. Progressive Fish Culturist $38: 649-656$.

Jensen, J. 0. T., and D. F. Alderdice. 1983. changes in mechanical shock sensitivity of coho salmon (Oncorhynchus kisut ch) eggs duri ng incubation. Aquaculture 32:330-312. Jensen, J. 0. T., W. E. M c l e a n, a nd D. F. Alderdice. 1981 . Effects of accessory factors on survival of newly fertilized salmonid eggs treated with an antibiotic. Aquaculture 23: $295-307$.

Johnson, S. C., G. A. Chapman, and D. C. Steves. 1983. Sinsitivity of steelhead trout embryos to handling. Progressive Fish Culturist. 45(2): $103-104$. 
Jordan, D., H. M. Lloyd, and R. Lloyd. 1964. The resistance of rainbow trout (Salmogairdncri Richardson) and roach ( Rutilus rutilus (L.)) to alkaline solutions. International Journal of Air and Water Pollution 8:405-4u9. King, H.W., E.F. Brater. 1976 Handbook of hydraulics for the solution of hydraulic fluid-flow problems. McGraw Hil 1, New York, USA.

Klontz, G. W., K. Focht, and P. Downey. 1979. A manual for salmon and trout production. Sterilly M Nelson and Sons. Murray, U t a h , USA.

Kramer,Chin \& Mayo. 1972. A comprehensive planning study of the Idaho fish hatchery system. Idaho State Department of Fish and Game.

Lemm, C. A. 1983. Growth and survival of Atlantic salmon fed semimoist or dry starter diets. Progressive Fish Culturist $45(2): 72-75$.

Lemm, C. A., and M. A. llendrix. 1981. Growth and survival of Atlantic salmon fed various starter diets. Progressive Fish Culturist 43(4): $195-199$.

Leon, K. A., and W. A. Bonney. 1979. Atlantic salmon embryos and fry: effects of various Incubation and rearing methods on hatchery survival and growth. Progressive Fish Culturist $41(1): 20-25$.

Li, M. W., and K. W. brolesen. 1977. Approaches to the analysis of energetic costsof intraspecific competition for space

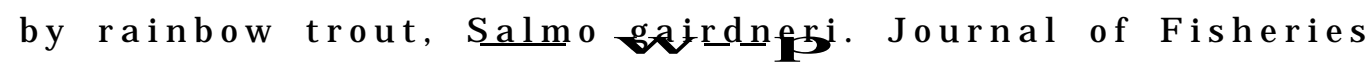
Biologists $11: 329-341$. 
Liao, P. B. 1971. Water requirements of salmonids. Progressive Fish Culturist $33: 210-215$.

Mahnken, C., E. Prentice, W. Waknitz, G. Monan, C. Sims, and J.Williams. 1982. The application of recent smoltification research to public hatchery releases: an assessment of size/ time requirements for Columbia River hatchery coho salmon (Oncorhynchus kisutch.) Aquaculture 28:251-268.

Markert, J. K., D. A. Miggs, I). MacQuarrie, J. K. McBride, B. S. Dosanjll, J. Vantine, and R. Reinhart.1984. Evaluation of the potential for using dry rather than semi-moist foods for culturing coho salmonin British Columbia hatchery facilities. 2. Quinsam Hatchery 1977 brood. Canadian Technical Keport of Fisheries Aquatic Sciences No.1260.

Miller, K. B., and F. Miller.1962 Diet glycogen reserves and resistance to fatigue in hatchery rainbow trout. Journal of the Fisheries Kesearch Board of Canada 19:365-375.

Moring, J. K. 1982. Fin erosion and culture-related injuries of chinook salmon raised in floating net pens. Progressive Pish Culturist 44(4): $189-191$.

Mundie, J. H., and K. E. Taber. 1983. Carrying capacity of an enhanced side-channel for rearing salmonids. Canadian Journal of Fisheries and Aquatic Sciences40: 1320-1322.

National Research Council. 1981. Nutrient requirements of coldwater fishes. National Academy of Science, Washington, D.C., USA. 
Nebecker, A. V., D. G. Stevens, and K. J. Baker. 1973.

Survival of salmon smolts in sea water after exposure to air-supersaturated water. Progressive Fish Culturist $41(1): 3 \mathrm{U}-33$.

Nikinmaa, M., A. Soivio, T. Nakari, and S. Lindgren. 1983.

Hauling stress in brown trout (Salmotrutta): physiological responses to transport in fresh water or salt water, and recovery in natural brackish water. Aquaculture 34:93-99. Oregon State Department of Fish and Wildlife. Annual progress report, fish research/culture project, infectious diseases, fiscal years 1981,1982 , and 1983 .

. Anadromous Fish Section. June 1, 1982. Comprehensive plan for production and management of OregonOs anadromous salmon and trout, part I, general considerations.

- 1984. Research and development publication list.

- 1985 Coho salmon plan status report.

- Computer printouts:

- Kelease of CWT Fish and Non-Coded Wire Fish by Hatchery by Brood by Species

-Releases of Coded-Wire Tagged Salmonids Beginning in 1980

-Liberations; Adult Deposition; Keleases of 'Tagged or Marked

-Fish by Hatchery, Species and brood Year; feed data; stock codes and water codes used by ODFWW. 
Papst, M. H., G. B. Ayles, and S. Uraiwon. 1982. A model to determine maximum growth of cultured rainbow trout (Salmo gairdneri). Canadian Technical Keports Fisheries and Aquatic Science $(1088)$.

Peterson, K. H., P. G. Daye, and J. L. Netcalfe. 1980 .

Inhibition of Atlantic salmon (Salmo solar) hatching at

low pll. Canadian Technical Keport Fisheries and Aquatic Sciences $37: 770-776$.

piper, R. G., I. D. McElwain, L. E. urme, J. P. McCraren, L. G. Fowler, J. K. Leonard. 1982. Fish hatchery management.

United State Fish and Wildlife Service. Washington, I). C. USA.

Plotnikoff, M. I)., D. A. Higgs, J. K. Markert, B. S. Dosanjh, J. R.McBride, and J. T. Buckley. 1983. Nutrition and marine survival of chinook salmon (Oncorbynchus tshawytscha). I.Potential role of smolt body composition (Kobertson Creek hatchery 1979 brood). Canadian Technical report of Fisheries and Aquatic Sciences No.1206.

Plotnikoff, M. D., D. A. Higgs, J. K. Markert, B. S. Dosanjh, J . R. McBride, a n d J. T. Buckley. 1984. Nutrition and marine survival of chinook salmon (Oncorhynchus tshawytsclla).

I . Further investigation of the potential role of smolt body composition (Robertson Creek hatchery 1980 brood). Canadian Technical Report of Fisheries and Aquatic Sciences No. 1235 . 
Privolnev, T. I. 1956. Kespiration of fish as a factor determining their distribution in bodies of water. Pages 125-148 in G. G. Wingerg, editor,Izvestiia Uniorkh, Volume 25 .

Kankin, D. P. 1979. The influence of un-ionized ammonia on the long-term survival of sockeye salmon eggs. Fisheries Marine Service Technical Report (9 12 ),

Katliff, D. E., K. L. Dill, and W. J. Grogerg, Jr. 1982.

Infectious hematopoietfc necrosis: a comparison of epizootics among fry hatched from saline-rinses and unrinsed steelhead eggs. Progressive Fish Culturist 44(4):217-220.

Kefstie, T. 1Y77. Effect of density on growth and survival of rainbow trout. Aquaculture 11:329-334.

Kefstie, T. 1982. The effect of feeding thyroid hormones on saltwater tolerance and growth rate of Atlantic salmon. Canadian Journal of Zoology. 60:2706-2712.

Kefstie, T., and A. Kittelsen. 1976. effect of density on growth and survival of artificially reared Atlantic salmon. Aquaculture $8: 319-326$.

Keinitz, G. L., and T. C. Yu. 1981 . Effects of dietary lipids on growth and fatty acid compositon of rainbow trout (Salmogairdneri). Aquaculture 22:359-366.

Rice, S. D., and J. E. Bailey.1980. Survival, size, and emergence of pink salmon ( Oncorhynchus gorbuscha Alevins) aftcr short-and long-term exposures to ammonia. Fisheries Bulletin $78(3): 641-$ b 48 . 
Ritter, J. A. 1975 . Relationships of smolt size and age with age at first maturity in Atlantic salmon, MAR/T-75-5.

Resource Development Branch, Fisheries and Marine Service Department of Fisheries and the Environment, Halifax, Nova Scotia, Canada.

Sandercock, F. K., and E. T. Stone. Undated. The effect of rearing density on subsequent survival of capilano coho. Canada Fisheries and Oceans, Pacific Regions, Salmonid Enhancement program. (Mimeographed.)

S a n d e r s, J. E., J. L. Fryer, D. A. Le ith, and K. D. Moore. 1992.

Control of the infectious protozoan Ceratomyxa Shasta by treating hatchery water supplies. Progressive Fish Culturi s t $34(1): 13-16$.

S a unders, K. L., E. B. Henderson, and P. K. H a r mon. 1963 . Effects of low environmental pll on smolting of Atlantic salmon (Salmo salar). Canadian Journal of Fisheries and Aquatic Science 40:1203-1211.

Schreck, C. B. 1982 . Stress and rearing of salmonids. Aquaculture $28: 241-249$.

Schreck, C. B., and L. C. Fowler. 1982 . Growth and reproductive development in fall chinook salmon: effects of sex hormones and their antagonists. Aquaculture 26:253-263. Seidel, P. K., and S. B. Mathew. 1Y77. Comparison of times of release by 1972 brood Cowlitz and Elokomin coho reared and released at Klickitat Ilatchety. Washington Department of Fisheries. Unpublished report. 
Senn, H. G., K. C. Hager, and C. W. llopley, Jr. 1974. Ef fects of experimentally varying size and time of release of hatchery-reared cohosalmon ( Oncothynchus kisutch). Washington Department of Fisheries.' Unpublished report.

Shelbourn, J. E. 1980 . Early growth rates of chum salmon fry (Oncorllynchus keta) in the laboratory in fresh and salt water. Canadian Technical Keport Fisheries and Aquatic Sciences (937).

Sili m, A., M. A. S. Y. Elazhary, a n d A. Lagace. 1982. susceptibility of trouts of different species and origins to various isolates of infectious pancreatic necrosis virus. CanLidian Journal of Fisheries and Aquatic Sciences 39:1580-1584. Smith, R. Z., and E. Wold. 1981 . Columbia Kiver Fisheries Development Program Annual Kepott Fiscal Year 1980. National Oceanic and Atmospheric Administration, National Marine Fisheries Service,Tectlnical Memorandum F/NIIC-1, National Technical Information Service Springfield, Virginia, USA. Speacker, J. L., and C. il. Schreck. 1980 . Stress responses to transportation and fitnessfor marine sursvival in coho salmon (Oncorhynchus kisutçh) smolts. Canadian Journal of Fisheries and Aquatic Sciences 37:765-769.

Statler, D.P., 1962 . Use of self-feeders for rearing steelhead trout at Dworshak National Fish Ilatchery. Progressive Fish Culturist 44(4): 195.

Steffens, W. $1981 \ldots$ Protein utilization by rainbow trout (Salmo gairdneri) and carp (Cyprinus carpio $)$ : a brief review. Aquaculture 23:337-34s. 
Sverdrup and Parcel and Associates, Inc. February 1985.

Advance Project Planning for Pollution Abatement Facilities, Leavenworth National Fish Hatchery, Washington, USA.

Tabachek, J. L. 1983 . Evaluation of grower diets for intensive culture of rainbow trout (Salmo gairdneri richardson). Canadian Technical Keport of Fisheries and Aquatic Sciences. ( 1178$)$.

Thompson, J.A. J., and D. W. Paton. 1976. Exposure of chum s a lmon (Oncorllynchus keta) to copper in a controlled ecosystem experiment(CEP'EA). Fisheries Marine Service Kesearch Development Technical Keport (660).

Thompson, J. S., and G. J. Paulik. 1967. An evaluation of louvers and bypass facilities for guiding seaward migrant salmonids past Hayfield Dam in western Washington. Washington State Department of Fisheries Kesearch Division. Olympia, Washington, USA.

Thruston, K. V., C. K. Phillips, K. C.Kusson, and S. M. Minkins. 1981 . Increased toxicity of ammonia to rainbow trout (Salmogairdneri) resulting from reduced concentrations of dissolved oxygen. Canadian Journal of Fisheries and Aquatic Sciences $38: 982-988$. 
United States Corps of Engineers, Walla Walla District. Lower Snake Kiver fish and wildlife compensation design memoranda: No. 3 Mar. 1978 McCall, Idaho Summer Chinook hatchery system.

No. 4 revision 1 July 1980 Lyons Ferry, Washington Fish Hatchery

No. 5 Sep. 1979 Lookingglass Careek, Oregon Fish $\mathrm{H}$ a t c h e r y

No. 7 Feb. 1980 Magerman National Fish Hatchery expansion

No. Y Jan. 1981 Dworshak National Fish llatachery expansion-spring chinook rearing

No. 11 Mar. 1983 Irrigon Fish Hatchery

No. 12 Mar. 1983 Wallowa Kiver Fish llatchery expansion

No. 14 Feb. 1982 Sawtooth Fish Hatchery

No. 15 Dec. 1981 revised Jul. 1982 East Fork Salmon Kiver satellite facility

Ifo. $16 \quad J$ u 1.1982 Crystal Springs llntchery

No. 17 Cleat-water Fish llntchery

No. 19 May 1938 Lyons Ferry Hatchery Tucannon Kiver satellite facility

United States Corps of Engineers, Walla Walla District.

February 1984. Manual: Sawtooth Fish Hatchery system operation, maintenance and fish culture. 
United States Fish and Wildlife Service. Manual of fish culture. Appendix 3.0 and 3.5 (Chinook \& Coho/Steelhead). . Division of Fish Hatcheries. Hatchery biologists semi-annual report for Washington, Oregon, Idaho: fiscal year incomplete $19801981,1982,1983$, and 1984 .

. October 1983. R. Region One,Little White Salmon/ Willard National Fish Hatchery complex, station development plan.

. January 9, 1984 . KKooskia National Fish Hatchery production history (May 1970 to May 1983).

. August 1 National Fish Hatchery, inventory May 1983$)$.

Vincent, R. E. 1960. Some influences of domestication upon three stocks of brook trout (Salvelinus fontinalis_ Mit Transactions of the American Fisheries Society 89:35-52.

Wahle, R. J., and R. Z. Smith. 1979. A historical and descriptivc account of Pacific Coast anadronous salmon rearing facilities and a summary of their releases by region, 19601976. National Oceanic and Atmospheric Administration, National darine Fisheries Service, Technical Keport SCKF736, Environmental Science Information Center, Kockville, Maryland, USA.

kashington, P. W. 1982. An analysis of factors affecting tne production of coho salmon (Oncorhyncilu kisutch) in the Columbia Kiver. Doctoral dissertation. University of Washington, Seattle, Washington, USA. 
Washington State Department of Fisheries. Inventory and use of facilities as of June 301976.

. Disease history summary (informal report)

January 2, 1979-June $13 ，$ 1983.)

. Salmon Culture Division. Hatchery reports.

Keports weekly and/or monthly for all Columbia Kiver anadronous WUF sites fur brook years 1981, 1982, and 1983.

. Salmon culture Division.

Cowlitz Salmon Hatcherty 1982 annual report.

Cowlitz Salmon Hatchery 1983 annual report.

Washougal Salmon Hatchery 1980-81 annul report.

Washougal Salmon Hatchery 1982-83 annual report.

Washington State Department of Game, February 10, 1978.

Goldendale hatchery feasibility study-steelhead facilities

( Gray \& Osbore, Inc.).

Fish health inspections July I, 1981-June 30, 1984.

Trout hatchery report-reports for all Columbia River

anadromous WIIC site s, covering brood years 1981, 1982, and 1983.

Wedemeyer, G. A. 1976. Harking Pacific salmon with tetracycline antibiotics. Canadian Journal o'f Fisheries and Aquatic

S c i e n c e 24(4):84Y-865.

Wedemeyer, G. A., and J. W. Wood. 1974. Stress as a predisposing factor in fish disease. United States Fish and Wildlife Service, Seattle, Washington, USA. 
Wells, N. A. 1935. Variation in the respiratory metabolism of the Pacific killfish (Fundulus parvipinnis) due to size, season and continued constant temperature. Physiological Z o ology H:318-335.

Westers, H. 1970 Carrying capacity of salmonid hat cheries. Progressive Fish Culturist 32:43-46.

Willoughby, H. 1968. A method for calculating carrying capacities of hatchery troughs and ponds. Progressive Fish Culturist 30:173-174.

Witschi, W. A., a nd C. I). ZicLell. 1979. Evaluation of pll shock on hatchery-reared rainbow trout. Progressive Fish Culturist $\mathbf{4 1 ( 1 ) : 3 - 5 . ~}$

wood,.I. w. 1974. Diseases of Pacific salmon: their prevention and treatment, 2nd edition. Washington State Department of Fisheries, Hatchery Division, Olympia, Washington, USA. 


\section{ADDITIONAL TECHNICAL KEPOKTS}

Oregon Department of Fish and Wildlife. Research and development publications:

\section{Progress Reports}

1Y7 7. Pribble, 11. Bonneville Hatchery.

1977. Smith, Mk Improving survival of spring chinook hatchery smolts in the Willamette Kiver.

1978. Pribble, M. Bonneville llatchery Evaluation.

1979 Hansen, H. An evaluation of fishery contribution from fall chinook salmon reared in Oregon Hatcheries on the Columbia Kiver.

1979. Hansen, M., D. E w i n g, a n d J. Matin. Bonneville Hatchery evaluation.

1979. Memmingsen, A., .I. Westgate, and Conrad. Development of techniques for salmon and steelhead trout hatcheries.

1979. Smith, PI. Improving survival of spring chinook hatchery smolts in the Willamettw Kiver.

1979. Westgate, J. Salmonid nutritional studies.

1380. Ewing, D., E. Birks, C. Fustish, A. Memmingsen, and 11 . Peterson. Hatchery practices.

1980. Hansen, H. An evaluation of fishery contribution from fall chinook salmon reared in Oregon hatcheries on the Columbia Kiver.

1980. Hansen, H. and S. Cramer. Bonneville llatchery evaluation.

1980. Smith, M., J. Hutchinson, and J. Zakel. Adult holding experiments, Willamette spring chinook studies.

1980. birks, E., A. Hemmingsen, J. Dentler, a n d D. E w i n g . Hatchery practices.

1980. Hansen, H. and S. Cramer. Bonneville llatchery evaluation.

1981. Westgate, J. tlatchery biology - Columbia Ri ver fishery development program.

1980. We stgate, J., J. Lag a s e, M. Woodall. Salmonid nutritional studies.

1982. Hansen, M. 5onneville tlatchery evaluation. 
1982. Hansen, Il., K. Johnson, and C. Thoming. An evaluation of fishery contribution from fall chinook salmon reared in Oregon hatcheries on the Columbia River.

1982 Hemmignsen, A., E. Kirks, J. Dentler, and D. Ewing. Hatchery practices.

1982 Westgate, J., J. Lagas se, L. Woodall, and T. Unterwegner. Trout/salmon nutrition studies.

Information Reports

1982. Johnson, S. A review and evaluation of release strategies hatchery-reared coho salmon.

1983 Williams, K. Releases of coho salmon into the upper Willamette Kiver, Oregon.

Federal A i d Pogress Reprts

1981 Hansen, H. An evaluation of fishery contribution from fall chinook salmon reared in Oregon hatcheries on the Columbia Kiver.

1983. Ewing, R. and A. Hemmingsen. Hatchery practices.

1983. Westgate, J., J. Lagasse, T. Unterwegner. Salmonid Nutritional Studies.

1983. Carmichael, K. Evaluation of Lower Snake Kiver Comp. Plan facilities in Oregon.

1983. Mansen, H Bonneville tlatchery Evaluation.

Washington State Department of Fisheries.

Fisheries Nanagemcnt Division reports.

1984-1 Closing report - operation and maintenance beaver Creek and Skamania hatcheries and Ringold Rearing Station, Jim Gearheard.

1984-2 Inventory of fish in hatcheries - February 15 , 1984.

1984-7 Uperation and maintenance - beaver Creek and Skanania hatcheries and Kingold Rearing Pond, Jim Cearhcard. 
1984-9 Wells hatchery stock analysis, 1982 broodstock, Ken Williams.

1984-11 A profile of Cowlitz River winter steelhead before and after hatchery propagation, Jack Tipping

1983-2 Inventory of fish in hatcheries - Febuary 15 , 1983. Jim Gearheard

1483-8 Fish planted in state waters - July 1, 1980J u n e 30, 1982 .

1982-3 Inventory of fish in hatcheries - February 15, 1982. with comparison to inventory of February 15, 1981. Jim Gearheard.

1982-8 Fish planted in state waters - July 1,1980 J i m Gearheard.

1982-19 Cowlitz steelhead rearing and production progress report - 1982 , Jack Tipping.

1981-20 Operation of fish facilities constructed with anadromous fish funds - statewide for period, J u l y 1, 1980 - J u n e 30, 1981, J i m Gearheard.

1981-33 Annual report for hatcheries and semi-natural rearing ponds, July 1, 1980 - J u n e 30, 1961, Jim Gearheard.

1981-3 Operation and maintenance - Beaver Creek and Skanania hatcheries and Ringold Rearing Station October 1, 1979 to Septem her $30,1980$.

1980-*6 Annual report - hatchcries and semi-natural rearing ponds July 1, 1979 - June 30, 1980, Jim Gearheard. 
1981-10 Inventory and hatcheries February 15,1981 with comparisons to February 15,1980 , Jim Cearheard.

1980-4 Operation and maintenance - Beaver Creek and Skamania hatcheries and Ringold Kearing Pond, K. W. Larson / J. Cearheard.

1980-5 Inventory of fish in hatcheries - Division Publication .

1980-6 Hatchjeres and semi-natural rearing ponds Annual Report, 1979-1979. Division Publication.

1980-7 Fish planted in state waters - July 1, 1979 J u ne, 30, 1979, Division Publication.

1980-18 broodstock Viral Survey: 1969-1980, Steve

\section{Roberts.}

1980-19 Development and management of federal aid migratory game fish rearing areas, S. Cross, J . C e a rhe ard, I I. Harty,

1980-22 hnadromous fish program progress report, James M. . Gearhen rd.

\section{$\underline{\text { Technical Keports }}$}

\#61. An evaluation of the effects of four tags used for marking juvenile chinook salmon (Oncorhynchus tshawytscha) (A pril 1981), Micheal E a m e s, Mark Hino.

\#65. Coded-wire tag loss study (August 1981), Lee blankenship. 
\#U9. Cowli tz almon hatchery and reservoir production and evaluation program, 1973 - Lloyd Phinney, Kevin Bauersfeld (October 1976).

\#30. 1976 Hatcheries statistical report of production and plantings - Bob Foster, Vie Fletcher, Bertha Kis e r ( J u ly 1977).

\#46́. Results of 1970 and 1972 brood Columbia Kiver co110 studies - C harles Moopley, Jr., Paul K.

Seidcl, Harry G. Senn, K o b e r t C . Mager (March 1978).

\#47. Cowlitz salmon hatchery and reservoir production and evaluation program, 1974 and 1975 - Paul R. Seide l, Charles I I. Mopley, J r. (March 1978).

\$49. Development and status of a salmon enhancement data base to evaluate new artificial production projects - Research \& Development Division (June 1978).

\#55. Salmon egg incubation investigation, July I, 1967 t o July 1,1977 - Ko b e r t F o s t e r (May 1978).

1501. Hatchery returns and spawning data for Columbia Kiver, 1960-1976 - Tony Kasch, bob Foster ( Hay 1378$)$.

\$62. $1 Y 76$ Kesults from micro-tagged salmon experimental groups - Tony Kasch (May 1978). 
\#73. Salmon egg incubation box program, 1977-78 Season - Richaard L. Allen, Larry R. Cowan August (1978.

1175. 1977 Hatcheries statistical report of production and plantings - Bob Poster, Vie Fletcher, Pam f77. A detailed listing of the liberations of salmon and steclhead trout into the open waters of the State of Washington during 1977 - Chuck Dunn, Vie Fletcher, Pam Coleman.

\# 931978 Hatcheries statistical report of production and plantings - Vie Fletcher, Pare Coleman, Peg): Hall ( O c to b e r 1975)).

\#94. A review of the experiments with the 1970 and 1371 brood coho salmon (Oncorhynchus kisutch) from thirteen Washington Department of Fisheries hatcheries - Carrie Bagatell, Kony Kasch, Chuck Johnson (October 1979).

\#96. A detailed listing of the liberations of salmon and steelhead trout into the open waters of the State of Washington during 1976 - Chuck Dunn, Peggy Hal 1, Vie Fletcher (October 1979).

\#99. Washington State proposed fish culture program, 1979-1980, Salmon and steelhead trout - Paul S e i d e l (March 190$)$.

\#103. Salmon culture program, 1979-1980 - Ross G. A n t ipa (March 19 80), 
8116. 1979 hatcheries statistical report of production and plantings - Peggy Hall, Vie Fletcher ( July 1980),

\#122. A detailed listing of the liberations of salmon into the open waters of the State of Washington during 1979 - Paul Seidel, Pam Coleman, Peggy Hall (August 1980).

\#127. A review of the 1973 brood coho salmon ( Oncorhynchus kisutch) coded-wire micro tagging experiments in Pugct Sound, Coastal, and Columbia River Areas by the Washington Department of Fisheries - Carrie Bagatrll, Tony Kasch, Chuch Johnson ( January 1981$)$.

6132. A detailed listing of the liberations of salmon into the open waters of Washington during 1980 Pam Coleman, Tony Rasch (April 1981).

\#139. A review of the experiments with the 1971 brood summer/fall chinook salmon (Oncorhynchus tshawytscha) released from Washington Department of Fisheries hatcheries - Carrie Bagatell, Howard Fuss, Tony Kasch, Chuch Johnson (June 1981).

\#143. A review of ttre experiments with the 1972 brood Spring and fall chinook salmon (Orcorhynchus tsllawytsctla) $\mathrm{r}$ e l e a s e d f rom eighteen Washingnton Department of Fisheries hatcheries - Howard Fuss, Tony Rasch, Chuck Johnson (August 1381). 
\#154. 1979 Kesults from micro-tagged salmon experimental groups - Dick O'Connor (February 1982.

\#160. A detailed listing of the liberations of salmon into the open waters of the State of Washington during 1981 - Pamela Castoldi, Tony Rasch (April 1982).

\#169. 1980 Kesults from micro-tagged salmon experimental groups - Dick O'Connor, Jim Packer (September $1982)$.

\#182. A review of the experiments with the 1973 brood spring, summer and fall chinook salmon (Oncorhynchus tshawytscha) releas ed from Washington Department of Fisheries hatcheries Howard Fus s, Tony Rasch - A p ril 1983.

\#185. A detailed listing of the liberations of salmon into the open waters of the State of Washingtion during 1982 - Pam Castoldi - April 1983.

\#193. 1981 Kesults from micro-tagged salmon experimental groups - Dick O'Connor, James Packer - August 1983.

\#196. A review of the 1975 and 1976 brood coho salmon (Oncorhynchus kisutch) experiments from Washingtion Department of Fisheries hatcheries Andrew Appleby, Tony Rasch - July 1983 . 
\#210. A detailed listing of the liberations of salmon into the open waters of the State of Washingtion d u r i n g 1983 - P a m e l a M. Mill - May 1984.

Washington State Department of Game.

Hall a n d Allee. 1971. Development of summer $r u n$ steelhead at Skamania Hatchery.

Simons. 11. 1973. Preliminary report of steelhcad Parr-smolt transformation study, Tucannon Hatchery, 1971-72.

Williams, K. 1975. An evaluation of trucking steelhead snrolts from Wells Hatchery to the Lower Columbia Kiver.

Washington Department of Came. 1969-1979. Operation of $\mathrm{f} i \mathrm{sh}$ ponds constructed with anadromous fish funds.

U.S. Fissh anbd Wildlife Service.

burrows, K., and ti. Chenoweth. 1970. The rectangular circulating rearing pond. Prog. Fish-Cult. 32(2):67-80.

banks, J., L. Fowler, and J. Elliott. 1971. Effects of rearing temperature on growth, body form, and hematology of fall chinook fingerlings. Prog Fish-Cult. 33(1):2u-20.

Burrows, K. lYb4. Effects of accumulated excretory products on Hatchery-reared salmonids. U.S. Fish Wild l. Serv. Res. Ke p. $6612 \mathrm{p} \mathrm{p}$.

Burrows, R., and B. Combs. 1968 Controlled environments for salmon propagat ion. Prog. Fish-Cult. 30(J): 123-136.

Elliot. J. 1969. The oxygen requirements of chinook salmon. Prog. Fish-Cult. 31(2):61-73.

Shanks, W.E., and B. D. Combs. 1975. Tests of efficiency of changes in filter media and filter design-unit: trickling filter--expanded shale media. U.S. Fish Wildl. Serv. Fish Cult. Dev. Ctr. (Abernathy, Wa.) Mimeo. 4 p p.

1975 Tests of efficiency of changes in filter media and filter design-unit: experiments with polystyrene bead media. U.S. Fish Wildl. Serv. Fish Cult. Dev. Ctr.

( A bernathy, Wa.) Mimeo. 5 p p.

banks, J. L., L. C. Yowler, and W. booker. 1974. Effects of four feeding levels and four loading levels on grrowth and conversion efficiency of coho finerlings in constant 53 degree F. water. U.S. Fish Wildl. Serv. Fish Cult. Dev. Ctr. (Abernathy, Wa.) Mimeo. 3 p p. 
Fowler, L. G., and J. L. Banks. 1972. A c celerated rearing of steelhead trout. U.S. Fish Wildl. Serv. Fish Cult. Dev. Ctr. (Abernathy, Wa.) Mimeo. 2 p p.

Fouler, L. G., and J. L. Banks. 1973. Accelerated rearing of steelhead trout. U.S. Fish Wildl. Serv. Fish Cult. Dev. Ctr. (Abernathy, Wa.) Mimeo. 1 p p.

Fowler, L. C., and J. L. Banks 1974. Accelerated rearing of steelhead trout. U.S. Fish Wild l. Serv. Fish Cult. Dev. Ctr. ( A bernathy, Wa.) Mimeo $1 \mathrm{pp}$.

Fouler, L. C., and J. L. Banks. 1975. Accelerated rearing of steelhead trout. U.S. Fish Wildl. Serv. Fish Cult. Dev. Ctr. (A bernathy, Wa.) Mimeo 1 p p.

Schreck, C. B. and L. C;. Fowler. 1982. Growth and reproductive development in fall chinook salmon: effects of sex hormones and their antagonists. Aquacul ture, 26:253-263.

Banks, J. L. 1974. Computer calculations of lot history production and hatchery production summary records. U.S. Fish Wildl. Serv. Sal. Cult. Dev. Ctr. (Abernathy, Wa.) Plimeo. $2 \mathrm{pp}$.

Banks, J. L., W. C. Taylor, and S. L. Leek. 1979. Carrying capacity recommendat ions for Olympia area national fish hat cheries. U.S. Fish wildl. Serv. Sal. Cult. Dev. Ctr. (Abernathy, Wa.) Mimeo. 57 p p.

Lagasse J . P., D. A . L e i t h, D. B . Roney, a n d O. F. Dahrens. 1980. Stamina and survival of coho salmon rearead in rectangular circulating ponds and conventional raceways. Prog. Fi shCult. 42(3): 153-15b.

Fowler, L. C., and K. burrows. 1971. The Abernathy salmon diet. Prog Fish-Cult. 33(2):67-75.

Powler, L.C., and J. Banks. 1972. Alternation tests of the Abernathy salmon diet, 1971 . U.S. Fish Wildl. Serv. Tech. P a p. 64.12 PP.

Yow le r, L. G., J. Banks,m and J. Elliot. 1972. Test of variations of the Abernathy salmon diet, 1970. U.S. Fis Wild l. S e r v. Te ch. P a p . $61.13 \mathrm{p} \mathrm{p}$.

Fowler, L. C. 1973. Tests of three vitamin supplementation levels in the Abernathy diet. Prog Fish-Cult.

35(4): 197-198.

1973. Coho production diets. U.S. Fish Wild]. Serv. Sish Cult. Dev. Ctr. (A bernathy, Wa) Mimeo. 4 pp. 
Fouler, L. G., and J. L. Banks. 1974. Dry diets for steelhead trout. U.S. Fish Wildl. Serv. Fish Cult. Dev Ctr.

( A bernathy, Wa.) Mimeo. 4 p p.

Fouler, L. G., and J. L. Banks. 1975. Dry diets for spring chinook salmon. U.S. Fish Wildl. Serv. Fish Cult. Dev. Ctr. ( A bernathy, Wa.) Mimeo. $6 \mathrm{pp}$.

Fowler, L. C. and J. L. Banks. 1976. Animal and vegetable substitutes for fish meal in the Abernathy diet, 1973 . Prog Fish-Cult. 38(3):123-126.

Yowler, L. G. and J. L. flanks. 1976. Fish meal and wheat germ meal substitutes in the Abernathy diet, 1974 Prog. FishCult.38(3):127-130.

Fouler, L. C;. 1980. Starting diets for chinook salmon fry. Prog. Fish-Cult.42(3):165-166.

Fouler, L. C. 1980. Substitution of soybean and cottonseed products for fish meal in diets fed to chinook and coho salmon. Prog.Fish-Cult.42(2):87-Yl.

Fouler, L. C. 1980 Feedjng trials with fall chinook salmon evaluating fish meals, fish oils, oat groats, and skretting diet. U.S. Fish Wildl. Serv. Sal. Cult. Dev. Ctr. (Abernathy, Wa.) Tech. Trans. Ser., No. 80-5.11 QQ.

Fouler, L. C. 1981. Protein and energy relation of starting diets for chinook salmon fry. Prog. Fish-Cult. 43(3): $151-152$.

Fowler, L. C. 1981. Tests of vegetable protein replacements and alternate ingredients in the Abernathy diet. U. S. Fish Wildl. Serv. Sal. Cult. Dev. Ctr. (Abecuathy, Wa.) Tech. Trans. Ser., No. $81-1.14$ p p.

Fowler, L. G. 1981. Effects of lipid and amino acid supplementation in chinook salmon diets containing poultry by-product meal. U.S. Fish Wildl. Serv. Sal. Cult. Dev. Ctr. (Abernathy, Wa.) Tech. Trans. Ser., No. 81-3. 12 pp.

Fouler, L. C. 1981. Evaluation of fish oils, condensed fish solubles, single cell protein, and additional minerals in in fall chinooks salmon diets. U.S. Fish Wildl. Serv. Sal. Cult. Dev. Ctr. (Abernathy, Wa.) Tech. Trans. Ser., No. $81-4$. 13 PP.

Combs, 8. 1968 An electrical grid for controlling trematodc cercariae in hatchery water supply. Prog. Fist)-Cult. 30(2):67-65. 
banks, J. L. 1977. A review of whitespot and coagulated yolk disease investigations at Lower Columbia River hatcheries, 1954-1976 and proposals for future studies. U.S. Fish Wild l. Serv. Sal. Cult. Dev. Ctr. (A bernathy, Wa.) Mimeo. 20 PP.

Fowler, L. 1972. Growth and mortality of fingerling chinook salmon as affected by egg size. Frog. Fish-Cult. 34(Z): 66-69

Fowler, L. C. and J. L. Banks. 1981. Delayed fertilization of fall chinook salmon eggs: A preliminary report. U.S. Fish Wild]. S e r v. Sal. Cult. Dev. C t r. (Agernathy, Wa.) Te c h. Transfer Series, No. 81-2. 6 PP.

Fuze, D. M., C . Kindschi, a n d J . L . Banks. 1981. Notes on the formalin treatment of fall chinook salmon eggs for fungus, Saproleenja sp. U.S. Fis h Wild. Serv. Sal. Cult. Dev. Ctr. (Abernathy, Wa. > Mimeo. 5 PP.

Fow le r, L. G. and J. L. Banks. 1980. Survival rates of three sizes of hatchery-reared fall chinook salmon. U.S. Pish Wildl. Serv. Sal. Cult. Dev. Ctr. (Abernathy, Wa.) Tech. Trans. Series No, $80-1.12$ PP.

Fowler, L. C., K. E. burrows, B. D. Combs, and A. E. Thomas. 1980. The effect of improved rearing conditions on the adult survival of fall chinook salmon. U.S. Fish Wild. Serv. Sal. Cult. Dev. Ctr. (Abernathy, Wa.) Tech. Trans. $\mathrm{Ser}$ ie $\mathrm{s} \mathrm{No}$. 80-2. $12 \mathrm{p} \mathrm{p}$.

Fowler, L. C., R. E . B u r r o w s, B. D Commbs and J . L . banks. 1980. The effect of size and time of release of fall chinook salmon fingerlings on adult survival. U.S. Fish Wildl. Serv. Sal. Cult. Dev. Ctr. (Abernathy, Wa.) Tech. Trans. Series No. 80-3. 13 pp.

Fow le r, L. C., R. E. burrows, B. D. Combs, and J. L. Banks. 1980 Effect of two rearing environments on the survival of adult fall chinook salmon. U.S. Fish Wild. Sal. Cult. Dev. Ctr. (Abernathy, Wa.) Tech. Trans. Series No. 80-4. 12 PP. 
Appendix A

Potential hatchery sites 


\section{Potential Hatchery Sites}

This appendix is a compolation of information currently available about potential sites for new hatcheries to rear anadrowous species in the Columbia Kiver basin. Government and private agencies concerned with the fisheries of the Columbia Kiver basin were asked for information on hand regarding potential aquaculture sites. Information obtained from these agencies ranged from detailed site studies to notes mentioning locations with a potential for development as fish rearing facilities.

In the late 1970's the US Corps of Engineers carried out detailed studies of the Snake Kiver system to locate potential hatchery sites as part of the Lower Snake Kiver Fish and Wildlife Compensation Plan. The Corps published the results of these studies in a series of reports that identified and compared potential sites for fish hatcheries in the Snake Kiver system.

Ground-Water Reconnasissance in Southeast Id aho

This Corps report recommends five sites for steelhead trout and gives information regarding an additional 134 potential sites. (US Army Engineer District, Walla Walla Corps of Engineers, July, 1978). For chinook salmon, five sites were recommended with three other potential sites listed. The report gives detailed information about the recommended sites and summarizes information as follows:

I . Recommended sites for steelhcad trout.

\section{A. Banbury Spring s}

The springsissue along a l/4-mile-long face of the Snake Kiver Canyon wall, discharging from the shallow permeable basalts at the contact with the underlying dense Banbury basalt. The line of springs is generally about 100 feet below the plateau rim. Spring flows are quite constant, usually ranging between 110 and 135 cfs; water temperature is essentially constant at $55-56$ degrees F (12.8-13.3 degrees C). There is no significant existing water use at the springs. The area around the springs, from the canyon rim to the Snake Kiver, is leased from Idaho Power Co. by the Snake Kiver Area Council Boy Scouts of Ame rica. Land on the plateau, immediately east of the springs, is privately owned--and land to the south is owned by the Idaho Department of Fish and Game. An adequate area near river level, which is not presently developed by the Boy Scouts is probably adequate for a hatchery site using spring water by gravity on a once-through basis. Effluent could discharge directly to the Snake Kiver. Access could be by improvement of an existing road, or construction of a new road. 
B. Malan Springs

The canyon of the Big Wood (Malad) Kiver below elevation about 3,100 feet contains very largesprings. The uppermost are collected with the river flow and diverted by flume for power generation farther down the canyon.

Additional springs (with apparent discharges adequate for hatchery needs) issue below the upper diversion, discharge into the river channel to join the upper powerplant tailwater, and are diverted again to a flume for the King Hill Irrigation District Main Canal and the lower power plant. Although not investigated in detail, it appears that sufficient spring flow could be obtained above elevation $2,920 \mathrm{feet}$, exclusive of river runoff, to meet hatchery needs. In mid-March 1978 the temperature of spring water at the upper diversion was 58 degrees F (14.4 degrees C), 54) degrees F ( 15 .U degrees C) at an unused spring below the diversion, and 56 degrees F(13.3 degrees C) in the river below the diversion. Summer flow of the river receives irrigation return flow at higher temperatures and may not be useable. Idaho Power Co. owns land on either side of the river, a narrow strip on the south side above the highway bridge, and a large parcel on the north side below the bridge. Hatchery supplies could be obtained by gravity flow, and the effluent probably returned to the King Hill Canal and Idaho Power Co. flume by gravity. Private property adjacent to Idaho Power property on the south side above the bridge is now used only for pasture.

\section{c. Thousand Springs}

Numerous spring outlets along the cliff face, at and near the contact with underlying less permeable Banbury basalt, discharge into the Idaho Power Co. flume about 120 feet below the rim. Several of the individual outlets discharge more than $100 \mathrm{cfs}$ each. The flow collected for power generation averages about $600 \mathrm{cfs}$ each, with a total flow in the area of about $1,000 \mathrm{cfs}$. Water temperatura in the flume at the larger inflow points is essentially 57 degrees F ( 13 .Y degrees C), although the temperature is nearer 52 degrees P ( 11.1 degrees C) at the Sand Springs diversion inlet point during cold winter periods. The temperature of the powerplanttailrace water averageges 55 degrees F ( 12.8 degrees C), or warmer. The land surroundin; the Idaho Power Co. property at the springs is privately owned and does not appear to he readily obtainable. Idaho Power Co. owns sufficient land for hatchery needs on the rim immediately above (east of) the springs. Water lifted about 120 feet from the flume could be returned to the flume above the power plant or could be dropped back about 300 feet to river level. Access to a rim site on Idaho Power Co. land would require acquisition of right-of-way along a section line for a distance of one-quarter mile, or across private land from the existing Thousand Springs road at the south. 


\section{Sand Springs}

Most of the spring discharge occurs at the northwest end of the existing spring pond and in the large spring alcove a few hundred feet toward the east. The springs are on the sloping shoulder of the upland, and represent discharge from the top of the regional water table. The total spring flow varies seasonally with irrigation and pumping on the plain to the north and east, ranging from about 80 to 115 cf $\mathrm{s}$. Id a o Power Co.diverts part of the flow downstream into the flume to their Thousand Springs Power plant, and some irrigation return water enters the spring discharge channel below the springs. kater temperature is nearly constant at 57.5 degrees P ( 14.2 d e grees C).

The springs and surrounding land are privately owned, except for two 40-*acre parcels of US-owned land about one mile south and southwest of the springs. A hatchery at either parcel, but especially the southwest, would be at essentially the elevation of the springs and some pumping would be required. Effluent discharge would be possible to the Idaho Power Co. pick-up point, or to Sand Springs Creek and the Snake Kiver. A hatchery could probably obtain gravity water if it were located on the private land along the creek.

\section{E. Briggs $\underline{\text { Springs }}$}

The majority of the spring discharge occurs within a large pool and nearby smaller outlets, and then flows westward in a single channel. The springs issue f rum t he talus near the contact between Snake Kiver basalt and older, probably Banbury, basalts in a relatively flat area. f 1 ow has been nearly constant in recent years, ranging between 105 and $115 \mathrm{cfs}$. Flow of as much as $150 \mathrm{cfs} h a s$ been reported. Water temperature is nearly constant at 57 degrees F ( 13.9 degrees C). Satisfaction of all existing water rights, including pending applications, would require diversion of essentially all the flow, although there is no use from the springs downstream for several hundred feet. The springs and immediately adjacent land are owned by Idao Power Co., with probably sufficient area for a hatchery to the south and southwest of the springs. because of the established diversion point for some existing water rights, some tailwater may need to be pumped. Otherwise, discharge could be directly to the Snake Kiver. Access would be easily provided by improvement of an existing road.

Forty acres immediately north of the springs on the bluff are US-owned and are adjacent to Idaho Power Co. land. The spring flows can be collected 100 feet above river level. A lift of about 200 feet would be required to the rim, with 300 feet of drop hack to the river. 
I . Other potential sites for steelhead trout.

A. Bickel Springs-Riley Creek-Billingsley Creek

Most of the water from these sources is already appropriated and used extensively for private, state, and federal hatcheries as well as for irrigation.

\section{B. Blue Springs}

The flow at these springs (about 60-65 cfs) discharges at or below the level of the Snake River and would be difficult to collect and utilize.

\section{C. box Canyon Springs}

The flow at these springs (about 400 cfs) is largely used for an existing private hatchery which occupies the only nearby land (which is across the river) suitable for a large hatchery.

D. Blue Lakes Springs

An average of about 200 cfs issues from basalt and talus and flows through a well-developed recreational area, a private residential area, and country club grounds with subsequent diversion for a large private hatchery west of the golf course.

\section{E. Clear Lake Springs}

Flow from several large spring areas making up the Clear Lakes group is used heavily for private trout hatcheries. Water is also used for irrigation and for power generat ion. Total discharge averages more than $500 \mathrm{cfs}$;. water temperature is about 5 b.6 degree F. There is a heavy commitment to existing development.

\section{F. Niagara Springs}

These springs are totally used by Idaho Power for a hatchery. Flow is 250 cfs or greater at 56.6-57 degrees F ( $13.7-13.9$ degrees C ).

\section{G. Crystal Springs}

Nearly all the spring dischargeis collected in a Flume and used by a private trout hatchery. Several spring outlets at the west end bypass the hatchery and flow through pond areas to the river. These flows are unmeasured, but appear to total less than $50 \mathrm{cfs}$. Water temperature in the flume is 57-58 degrees f (13.9-14.4 degrees C). 
Several springs in deep alcoves discharge through two channels to the Snake Kiver. The principal discharge is through the upstream channel and averages about 38-45 cfs. The lower channel has only about $8 \mathrm{cfs}$. Water temperature varies from 57-60 degrees F (13.9-15.6 degrees C) seasonally. The springs are unused, but are privately owned. The present owner holds filings on the total flow for hatchery and other uses. No site is available for a hatchery except about five acres on the alcovefloor.

\section{Jerome Area}

The lava plateau area south and west of Jerome between Interstate Highway I-80N and the Snake Kiver canyon rim is underlain by the SnakePlain aquifer with the potential for wells yielding an average of $3-5$ cfs per well. The ground is little used in the area because of the extensive delivery system of the Twin Falls North Side Canal.

A well field of 15 wells capable of producing about 50 cfs could be constructed in most parts of the area. Depth to static water level would be from about 100 to 350 feet below land surface, depending upon land-surface elevation at the well site. If wells were spaced about 500 feet apart, the pumping and interferencedrawdown would be only a few feet, so lifts would be essentially the same as depth to water. Seasonal area water-level fluctuations would be in the range of 3-6 feet. Pumping the required 5 U cfs from a field of $15-$ wells within 10,000 feet of the springs below the canyon rim should be expected to cause up to two feet of head decline at some of the springs, with some consequent reduction of spring flow. If about 704 is assumed for overall pumping efficiency, it would require about 13.25 million Kwh of electricity annually to lift 50 cfs an average of 250 feet (Figure 2 ).

Water temperature would be essentially constant at about 58 to 62 degrees F (14.4-16.7 degrees C), with relatively uniform quality. Potential for contaminants from return water off agricultural and industrial lands would be of the same order as that at the canyon springs. Effluent discharge might be to irrigation canals or to the Snake Kiver through drainageways. A large part of the area is privately owned.

\section{J. Shoshone Area}

West of the Milner-Gooding canal, and southwest of the Snoshone-Diet ri chq area, the potential for large capacity wells is similar to that near Jerome. Depth to water is about 250-325 feet, however, and seasonal variations of water level are slightly higher--10 to 25 feet. Propcrly constructed wells about 400 feet deep should yield up to 5

$$
\text { A - } 5
$$


cfs each with only a few feet to drawdown. Cround water in this area is Influenced by recharge from the canal and from the big Wood and Little Wood Kiver systems. As a result, water temperature and quality may be somewhat more variable. Water at 60 degrees F ( $15 . b$ degrees C) and of adequate quality for hatchery use would be expected, however. Effluent discharge might be to irrigation canals or laterals, or to recharge spreading ponds on the permeable lava surf ace.

\section{K. Minidoka-Paul A r e a}

Wells about 275-300 feet deep drilled into the Snake Plain' aquifer west and northwest of Minidoka and Paul are capable of yields up to about 4 cfs. The groundwater in the area is heavily developed for agriculture, but static water levels fluctuate through only a few feet seasonally and are from 130 to 150 feet below land surface. Water temperature is somewhat cooler than west of the Milner-Gooding Canal, ranging from about 54 to 59 degrees F (12.2-15.0 degrees C). Water quality would be good, subject only to return-water contaminants as with all areas on the south margin of the plain. Effluent discharge might be to irrigation canals and laterals. Most of the land in the area is privately owned.

\section{Mud Lake Area}

North of Mud Lake and east of Plonteview ground water occurs in highly permeable lava and gravels near land surface. Wells capable of 5 to $8 \mathrm{cfs}$ each, with good quality water at temperatures of 52 to 56 degree F (11.113.3 degree C), may be obtained. At proper locations wells only 150 to 200 feet deep may yield large quantities with small drawdown from static water levels that are only a few feet below land surface. Discharge of effluent to irrigation canals and to irrigation storage reservoirs would appear feasible most of the year. During November to March, however, low air temperature and heavy snow might restrict or hamper operations.

\section{Kexburg Area}

Snake Kiver gravels and interbedded lavas, west' of the Henrys Fork Kiver west of Kexburg, yield large volumes of ground water to wells. Wells capable of 5 to $8 \mathrm{cfs}$, discharging from only 10 to 150 feet below land surface, can be obtained with well depth of 250 to 300 feet. The water temperature ranges from 50 to 54 degrees F (10.0-12.2 degrees C) possibly too cold for steelhead, but usable for Chinook salmon. Water is of excellent quality, and effluent discharge could be to the Snake River or irrigation canals. Large use is made of surface water in the areafor irrigation, but the ground water is not so heavily developed. 
Elk Creek rises in large springs near the railroad siding of Trude, and flows south to Buffalo Kiver. Good access, Forest Service land for sites, and adequateflows and temperatures are available.

Toms Creek is tributaryto Buffalo Kiver and offers a potential for hatchery use. Sites on US Forest Service land appear feasible, but streamflow below spring outlets will be subject to large temperature ranges. Temperature control may be possible if spring discharge can be picked up and protected by pipeline.

IV. Other potential sites for chinook salmon.

A. Chilly Sinks-Mackay Keservoir Area

Streamflow of the big Lost Kiver sinks into permeable gravels just below Chilly Buttes, above MacKay, to maintain the ground-water reservoir full to overflowing. The ground water moves at shallow depth down-valley to reappear in a multitude of marshy seep and spring areas in the backwaters of $\mathrm{Mackay} \mathrm{Dam}$ and reservoir. This emerging ground water is too broadly distributed to economically collect for hatchery use. Wells with low lift and potential for large yields offer a better potential, although the ground-water conditions of the area have not been adequately explored. There appears a potential, however, for a hatchery supply with no apparent quality problems and probable water temperature range of about 4 U to 55 degrees F (4.4-12.8 degrees C). The effluent could be discharged directly to MacKay Keservoir.

\section{B. Big Sprint; Creek (Little Lost Kiver V Valleys)}

Ground water in the valley fill moves down-valley below Clyde at a gradient flatter than that of the land surface. At the head of Big Spring Creek the ground water discharges to land surface in several springs, moving down-valley in two or more surface channels separate from Little Lost Kiver. The combined flow of the two largest and most prominent springs is about 25 cfs, varying seasonally through a small range. The springs are on private property, but the channels combine on public land a mile or more downstream. Water temperature at the main spring outlet was 43 degrees F (6.1 degrees C) in March 1978 , and is expected to range upward to about 54 degrees F 12.2 degrees C) in late summer or fall. Other outlets are expected to be the same.

Beaver ponds immediately below the springs restrict the streamflow and large variations in water temperature occur downstream. For hatchery use, flow of the spring would need to be picked up at the outlet and conveyed in a protective manner to maintain uniform temperature. Access would be easy, and effluent discharge could be back to Big Spring 
Creek.

Farming immediately upstream, with major sheep and cattle populations, might pose contaminant problems. Upvalley pumping is minimal and should not affect spring flow s e riously.

\section{Snake River Ground Water Near Kexburg}

West of the Henrys Fork River, near Kexburg, the gravel and lava sequences readily recharged from the Snake Kiver and Henrys Fork yield ground water in large quantities to wells. Large diameter wells $25 \mathrm{U}$ to 300 feet deep, with water levels near land surface, are capable of yielding 5 to $8 \mathrm{cfs}$ each, at a temperature of about 50 to 54 degrees F ( $10.0-12.2$ degrees C). Effluent discharge would be to irrigation canals or back to the Snake Kiver. 
I I . Recommended sites for chinook salmon.

\section{A. Hamilton Springs (Big Lost Kiver Valley)}

Two or three principal discharges and several smaller ones issue from moderately metamorphosed limestone and Limey sandstone at the west valley margin. One principal channel flows from the spring area, carrying a relatively uniform 25 cfs or greater at a water temperature ranging from 46 to 54 degrees F ( 7.8-11.7 degrees C). The springs and surrounding land are privately owned. Access is by well-maintained gravel road. Effluent discharge is readily available back to the creek that is tributary to Mackay Keservoir. Pick-up of spring flow at the source would be easily and cheaply accomplished, and an ideal site for once-through gravity operation.

\section{B. Birch Creek Above blue _Dome}

The headwater drainage area of Birch Creek feeds the broad, alluvial valley above Kaufman Guard Station. A basalt ridge, underlying fanglomerate, and cross-basin faulting all restrict down-valley ground-water flow, forcing ground water to the surface in several springs upstream of the basalt constriction. The collected spring flow averages about 70 cfs with water temperature ranging from about 40 to 55 degrees F ( $4.4-12.8$ degrees C>. both US Forest Service and ldaho State Fish and Came property are usable for hatchery siting. Access is good, and effluent could be returned to Birch Creek. To maintain acceptable temperature, spring flow must be collected near outlets and conveyed under protection. There is essentially no present activity above the springs that would threaten water quality. A recent application has been made' to appropriate essentially all of the flow of the two channels of birch Creek at a point about $3 / 4$ mile above the Forest Service 160 -acretract. The application is for fish propagation with return of the water immediately to the Birch Creek channel. These fish ponds, if constructed, should not have any adverse effect on the availabliity or quality of water to the proposed facility.

\section{Big Springs Creek Near Leadore (Lemhi River Valley)}

Down-valley of Leadore the valley-fil 1 alluvium narrows and thins so that both the Lemhi River and big Springs Creek become ground-water drains. Ground water moving down valley appears at the land surface in a number of seeps and streamed springs, furnishing a flow of 25 cfs or greater to Big Springs Creek. The Flow accumulates over a broad area, and derives from relatively shallow circulation of ground water. Consequently, the water temperature may reflect the considerable range of air temperatures. If the discharges could be collected and protected, a water temperature range 
of about 40 to 54 degrees F (4.4-12.2 degrees C) could be maintained. Because of agricultural activity and mining upvalley, there may be potential for contamination.

D. Pahsimeroi Valley Ground Water _ Near_ May_

Valley-fill alluvial sand and gravels near Play and below big Creek contain largesupplies of ground water. Wells 50 to 300 feet in depth, depending on location and land surface elevation, yield as much as 7 cfs. Average yields of 3 to 5 cfs are possible in several areas, where existing wells have water levels only a few feet below land surface. Pumping drawdowns of 10 to 25 feet can be expected. Water is of excellent quality with little threat of contamination, and would maintain a uniform temperature of about 50 to 55 degrees F (10.0-12.6 degrees C). A well field yielding up to 25 cfs would have a significant impact on water levels in the vicinity, however, and would require further detailed study for siting. Effluent discharge would be to irrigation or to the Pahsimeroi Kiver. Sulphur Creek Spring has the only large ground-water discharge in the area, but has a temperature of about 58 degree F; the flow is only about 15 cfs.

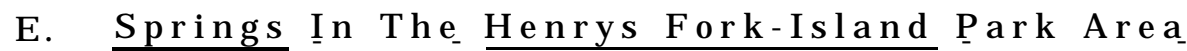

Several spring-fed sources from the lava plateau area between Henrys Fork and Warm Kiver at the Wyoming boundary, in extreme northeast Idaho, of f e $r$ potentially useable hatchery supplies. The area is remote from planting sites and winter climatic contlitions may cause severe operating problems.

Big Springs near Island Park discharges up to 200 cfs at a relatively constant 50 to 53 degrees F (10.0-11.7 degrees C). The spring area itself is not accessible for hatchery use, but within a mile downstream there are potential sites on US Forest Service land that appear useable. The large flow rate and short surface-flow distance probably would permit control of temperature within useable range.

Moose Creek and its principal tributary, Lucky Dog Creek, are tributary to henrys Fork just downstream of big Springs. These have sufficient flow of good quality water and several possible sites on US Forest Service land. Temperature variation during winter months may be large unless the supply is obtained very near the spring outlet.

Moose Creek springs are in a canyon area without hatchery sites, but sites exist downstream where water temperature ranges may not be extreme. 
Site Selection Study for a Steelhead Hatchery.

The Corps of Engineers followed up the preceding study with a site-selection reportfor a steelhead hatchery on the Snake River in central Idaho (US Army, Engineer District, Walla Walla, Corps of Engineers,. October, 1978). The site-selection study concluded that the best location for a steelhead hatchery is the Malad River site. An adequate supply of good quality water is available from springs along the south bank of the Malad Kiver between the Upper and Lower Idaho Power Company dams. Land may be available, there is ready access to the site, and environmental factors are favorable.

Ground-Water Investigation of the Upper Crande Ronde River Basin

The: objective of this investigation was to determine whether there is an adequate water supply for a steelhead hatchery in the Crande Konde valley (US Army, Engineer District, Walla Walla, Corps of Engineers, August, 1978). Two perennial streams were considered for a hatchery site, the Grande Konde Kiver and

Catherine Creek. Both streams have annual flow although at times the flow is minimal.

Two potential sources of ground water for a hatchery are basalt aquifers and the valley fill alluvium. The contractor concluded that aquifers in basalt strata are not sufficiently defined for location or yield characteristics to be considered a water source for a steelhead hatchery, with the exception of the Elgin area which should be investigated further.

The Grande Konde valley isfilled with allulvial sediments to varying and unknown depths, and wells have been constructed which indicate that aquifers exist to a depth of 300-400 feet. The conclusion of this study is that ground water exists in the alluvium with sufficient quantity, quality, and temperature to fulfill the requirements of a steelhead hatchery, but that the success of the project revolves around a favorable ruling for the farmers relative to hatchery water use.

Ground-Water Reconnaissance in Northern Idaho.

The US Corps of Engineers also made a study under a contract to investigate ground water supplies in northern Idaho as a source of water for new fish hatcheries (US Army, Engineer Distrisct,Walla Walla,Corps of Engineers, September, 1978). This study recommended three potential sites and commented on them as follows.

$\underline{\text { Mathdrum Prairie }}$

Coarse gravels underlie most of the Rathrum Prairie in Idaho with a capability of yielding large amounts of water (4-7 cfs) to individual wells with little drawdown. The water table is at an elevation of about 2,000 feet; depths to water are about 150 to 200 feet in the area from the 
Washington-Idaho boundary to Post fal ls. There is ample recharge to the aqulifer, from infiltration of rainfall and seepage loss from lakes bordering the prairie, to sustain a subsurface flow through the aquifer of possibly 1,000 cfs at the state line. Water quality is good, with temperatures expected to be essentlally constant in the range of 47-51 degrees F (8.5-11 degrees C). Essentially all property suitable for a well field and hatchery site is in private ownership. Effluent from a hatchery could probably be reused for irrigation during summer months. In the nonirrigation season, however, it would probably have to be conveyed to the Spokane River channel.

\section{$\underline{\text { Cabinet }} \underline{\text { Gorge }} \underline{\text { Area }}$}

In the vicinity of Cabinet Gorge Dam, on the Clark Fork river near the Idaho-Montana border, a deep gravel-f il led ancient river channel is a potential area for large-scale ground-water development from wells. Natural ground-water flow westward through the old, buried channel was greatly augmented by the construction in 1952 of Cabinet Gorge Dam along a reach of about 3 miles of the south bank below the 150 feet, depending upon the ground elevation at the site. Essentially all of the land suitable for a hatchery site in the vicinity is in private ownership. Water quality should be excellent,with temperatures probably in the range of $40-$ 55 degrees F (4.5-13 degrees C). Effluent from a hatchery could be returned directly to the river without difficulty. The valley-floor area across the river from the town of Clark Fork is another potential for a well field and hatchery site,with anticipated pumping lifts lessthan 50 feet. The area is also entirely in private ownership.

St. Maries A r e a

Although there is no direct information on groundwater availability near St. Maries, there should be a buried river channel (near the confluence of the St. Mries and St. Joe rivers) that is 300 to 500 feet with as much as 100 feet or more of coarse, water-bearing sands and gravels in the lower part. Water levels in wells should stand at or above land surface with individual wells expected to yield from 3.5 to 5 cfs of good quality water. Temperatures should be constant at about 45-513 degrees F (7.5-10 degrees C). Some exploratory drilling, possibly supplemented by some geophysical surveys, would be required to confirm the anticipated conditions. The area of land suitable for development outside the Coeur d'Alene Indian Keservation, is limited in extent and all in private ownershop. Hat chery effluent could be returned directly to the river channel. 
Hid-Columbia Kiver Study.

An extensive survey for hatchery sites in the mid-Columbia Kiver area was carried out by the Public Utility District of Chelan, Douglas, and Grant counties through a contract with Frederiksen,Kamine and Associates, Inc. - (Chelan County PUD, Douglas County POD, Grant County PUD, 1981). Fifty-three sites were identified and rated in Table 1 . The best 16 of these sites and their water potential are listed in Table 2. Excerpts from the report on the top 16 sites follow.

TABLE 1

L I S T I N G AND RATING O F S I T E S IDENTIFIES FOR FISH CULTURE PROGRAM IN MID - C OLUMBIA AREA

\begin{tabular}{|c|c|c|c|c|c|c|}
\hline \multirow[t]{2}{*}{ Site } & \multirow[t]{2}{*}{ County } & \multirow{2}{*}{$\underset{1}{\mathrm{Full}}$} & Hatchery & \multicolumn{3}{|c|}{ S a tellite } \\
\hline & & & $2 \quad 3$ & 1 & 2 & 3 \\
\hline Pasco Drain & Franklin & & $\mathrm{X}$ & $\mathrm{X}$ & & \\
\hline Kingold $\mathrm{Di}$ t $\mathrm{ch}$ & Franklin & & $\mathrm{X}$ & $\mathrm{X}$ & & \\
\hline Priest Kapids Hatchery & Grant & $\mathrm{X}$ & & $\mathrm{X}$ & & \\
\hline Richland C a n a l & Henton & & & & & $\mathrm{X}$ \\
\hline Baker Pond & Benton & & & & & $\mathrm{X}$ \\
\hline Horseshoe Pond & Yakima & & & $\mathrm{X}$ & & \\
\hline Kichland Pond & Benton & & & & & $\mathrm{X}$ \\
\hline Kiona Canal & Benton & & & & $\mathrm{x}$ & \\
\hline Ahtanum Creek & Yakima & & & & $\mathrm{X}$ & \\
\hline Wide Hollow Creek & Yakima & & & & $\mathrm{X}$ & \\
\hline Nile Spring & Yakima & & & & $\mathrm{x}$ & \\
\hline Naches Hatchery & Yakima & & & & & $\mathrm{X}$ \\
\hline Tieton Dam Spring & Yakima & & & & & $\mathbf{A}$ \\
\hline Gold Creek & Yakima & & & & & $x$ \\
\hline Wildcat Creek & Yakima & & & & & $\mathrm{X}$ \\
\hline Nelson Springs & Yakima & & $\mathrm{X}$ & & $\mathrm{x}$ & \\
\hline Cle Elum Ponds & Kittitas & $\mathrm{X}$ & & & & \\
\hline $\mathrm{Cle}$ Glum $\mathrm{P}$ it s & Kittitas & $\mathrm{X}$ & & & $\mathrm{X}$ & \\
\hline Easton Ponds & Kittitas & $\mathrm{X}$ & & & & \\
\hline Tjossen Pond & Kittitas & & & & $\mathrm{X}$ & \\
\hline Shea Creek & Kittitas & & & $\mathrm{X}$ & & \\
\hline Unnamed Creek & Kittitas & & & & & $\ddot{x}$ \\
\hline Manastash Creek & Kittitas & & & & & $\mathrm{x}$ \\
\hline Parke Creek & Kittitas & & & & & $\mathrm{x}$ \\
\hline Carl bou Creek & Kittitas & & & & & $\mathrm{x}$ \\
\hline Coleman Creek & Kittitas & & & & & $\hat{x}$ \\
\hline
\end{tabular}

1 Kating: $1=$ Good, $2=$ Acceptable, $3=$ poor $\underline{\text { Pasco Drains. }}$ 
Nanum Creek

Unnamed Spring,

Caribou Creek

Kittitas

Umtanum $\mathrm{C}$ re e $\mathrm{k}$

Wilson Creek

Kittitas

Kittitas

Kittitas

Colockum Creek

Chelan

Rocky Ford Creek (WL)G)

Grant

Grant

Trout Lodge

Crant

Collin Skane

Seep Lakes Spring

Drain 239 (Qulncy)

Drain Well (D-86-1)

Crant

Grant

Quincy Drain Wells

Grant

$1,2,4,5$

Grant

Lower Crab Creek

Kocky Reach

( Turtle Rock)

Kocky Reach (Annex)

Grant

Douglas

Douglas

Rock) I s land Creek

Douglas

Douglas Creek

Dryden Power Canal

Douglas

Chelan

Schmi t ten Pond

Chelan

Leavenworth NYH

Entiat NFH

Wells Hatchery

Chelan Hatchery

Winthrop NFH

Methow Kiver Pens

Pateros $\mathrm{Hatch}$ ery

Chelan

Chelan

Chelan

Chclan

Okanogan

Okanogan

Okanogan

Chief Joseph Dam

Okanogan

X

X

X

$\mathrm{X}$
$\mathrm{X}$

$\mathrm{X}$

$\mathrm{X}$

$\mathrm{X}$

$\mathrm{X}$

$\mathrm{X}$

$\mathrm{X}$

$\mathrm{X}$

$\mathrm{X}$

$\mathrm{X}$

$\begin{array}{ll}x & X\end{array}$

$\mathrm{X}$

X

$\mathrm{X}$

$\mathrm{X}$

X

X

$\mathrm{X}$

$\mathrm{X}$

$\mathrm{X}$

X

$\mathrm{X}$

$\mathrm{X}$

$x$

$\mathrm{x}$

X 
TAHLE 2

WATER POTENTIALLY AVAILABLE POK EXPANDED FISH PRODUCTION PROGRAMS IN THE MID-COLUMBIA AREA

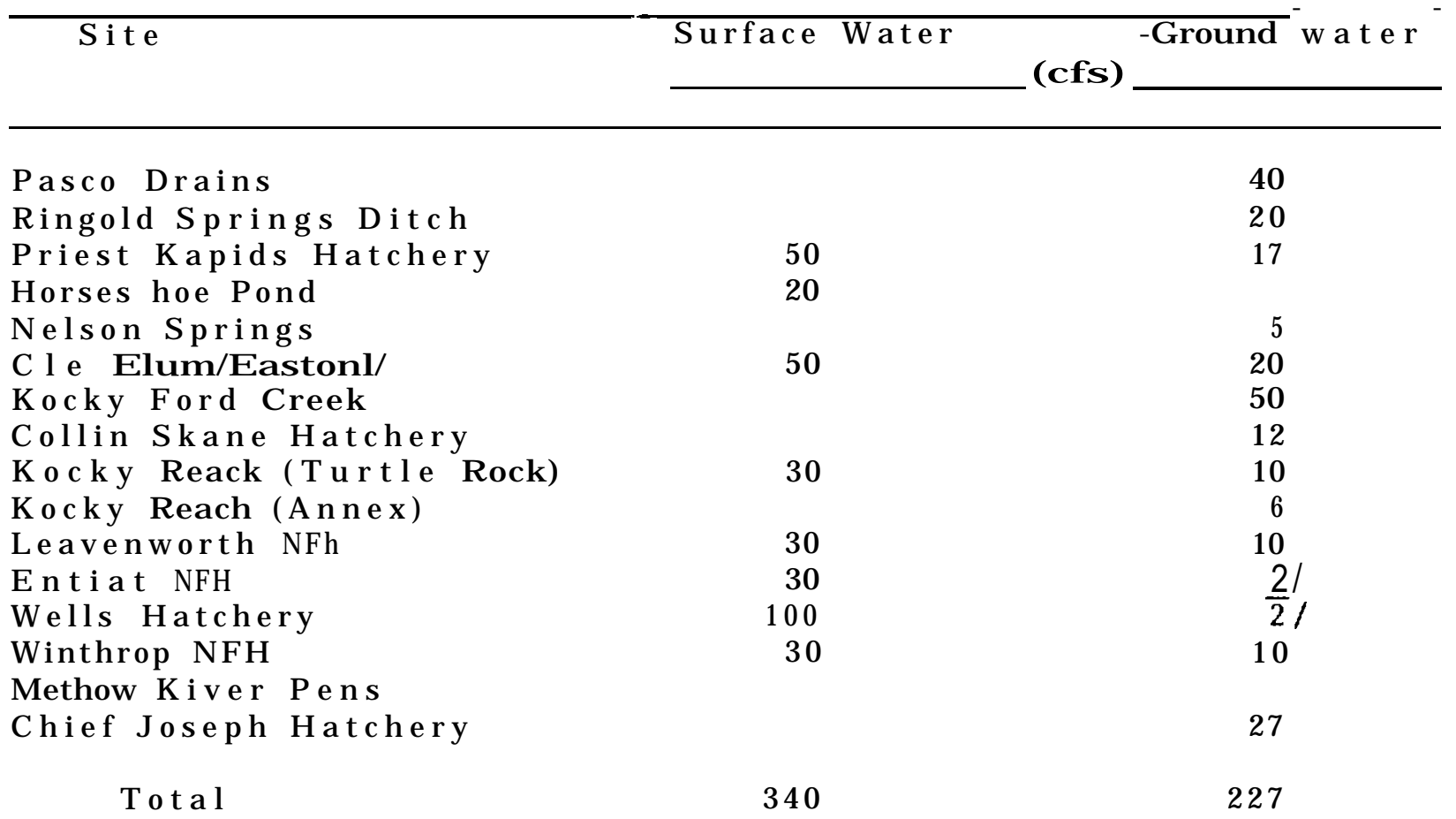

1. The potential for ground water is speculative. FM believes that more than $20 \mathrm{cfs}$ could be developed in this area.

2. Aqulifer development

Pasco Drains.

The drains are located in and around Pasco, Washingtion, in the drain ditches behind the river levees. Drain water similar to Rngold Springs water consists of irrigation return flows that filter through the soil from the adjacent farmlands to the drain ditches. The drain water is now being pumped over the levees to maintain a lower water table in the area. In a recent search for hatchery sites for Snake River salmon and steelhead, the drain water in the Pasco area was considered but it was dropped from consideration in favor of the Lyons Perry site.

The river levees raise concerns about the quality of the water for use in a complete hatchery facility; however, the quality appears to be similar to that of the Ringold Springs supply. Therefore,the contractor believes that, within the scheme of an expandedfish cultural program water from three or four of the levees' ditchescould be used to great advantage for satellite rearing stations. 


\section{Ringold Springs Ditch.}

Ringold Springs is a rearing area for steelhead and chinook salmon. Salmon ponds were constructed and they are operated by the Washington Department of fisheries (WDF). The downstream steelhead ponds were constructed and they are operated by Washington Department of Came (WDG). The spring water used originates from a shallow aquifer being supplied by irrigated farming at higher elevations. The National

Marine Fisheries Service provides annual funding for both facilities; however, Grant County has provided some funding.

While the hatching of eggs should not be considered, the expansion of the Ringold Springs area,similar to the existing program, has been proposed for many years by WDG and WDY. WDC has been satisfied with it 6 steelhead program (Ayerst, personal communication) as is WDY with the spring chinook survival and catch rates associated with this operation (Hopley, personal communication).

Priest Kapids Hatchery.

Priest Kapids Hatchery is located on the left bank immediately downstreamfrom the Priest Rapids Dam. It is owned by Grant County PUD and operated by WDF.

This site has one of the greater potentials of those identified during the study. Mike Del 1, biologist for Grant County PUD, informed the contractor that approximately 20 cfs of water was obtained from five shallow wells developed in November of 1980 ; however,the long-term projection level of water production is still unknown. Two of the wells four cfs each) will be capped for future expansion. Dell further stated that the water aquifer might yield another nine cfs from additional well drilling, for a total of 17 cfs for future expansion. This water along with the 18 cfs now developed and programmed could result in up to 35 cfs of high-quality ground water at this site.

Horseshoe Pond.

As a satellite to a larger hatchery complex, Horseshoe Pond, located near Mabton along the Yakima Kiver, may afford a great opportunity to rear fish economically (Rose, 1971, and Bakkala and Gangmark, 1965). The horeshoe Pond operation would be similar to the WDF rearing program at the Olympia, Washington, Percival Cove facility. This 26-acre pond with its 10 to 20 cfs flow has reared up to 8.0 million fall chinook. WUP is again programming fall chinook rearing of this magnitude in this pond (Antipa, 1980). The general production concept would be to eradicate all fish within tlorseshoe Pond, screen the inlet and outlet, develop a flow 
of 10 to 30 cfs with pond drainage capabilities,import hatchery-incubated two-week-old fall chinook, and rear them until they reach 80 to 100 per lb;then they will be released by draining the pond.

Nelson Springs.

These two springs are located between Naches and Yakima, Washington. WDG has constructed a $100-$ foot-long wooden raceway at the site utilizing only the northernmost spring. The two springs combine immediately downstream from the raceway. Fish rearing at this location has been terminated because of funding shortages.

Concerns by contractor staff centered around the expanding housing development within the several-square-mile watershed of Nelson Springs upstream of i ts two major forks near Nelson Bridg on the Naches Kiver.

Looking on the positive side, this gravity water source is equal in volume to that at the Naches Trout Hatchery. Area for a rearing facility on County property at this site is adequate. Additional groundwater may be present, and pumping Naches Kiver water should not be ruled out as a means to further enhance this development.

\section{$\underline{\text { C l e Elum/Easton. }}$}

In the upper Yakima system near the towns of Cle Elum and Easton, a very shallow ground water aquifer exists in areas adjacent to the river (personal communication with employees of the Cle Elum City Water System). All areas between Ellensburg and Easton where gravel was removed for highway construction have standing water, with many ponds having flowing outlet6 (Larry brown). The abandoned salmon rearing pond areas at Cle Elum and Easton for example, have outlets flowing at 4 to 15 cfs and 2 to 8 cfs, respectively (Ptrinney and Kral, 1965). In October and November of 1980 the contractor noted flowing outlets on the above two sites and others in the area between Ellensburg and Easton. In addition, many of these ponds were observed to freeze over very slowly, indicating they were being warmed by ground water.

Land availability is another plus. The majority of these gravel borrow pits are owned by the Washington State highway Department. Host areas will lend themseles to easy access and construction.

Kocky Ford Creek.

The springs that constitute the headwaters for Kocky Ford Creek provide morethan 50 cfs of high-quality spring water. The WDG, which owns the water source and surrounding 
land on which the old Trout Lodge is located, has been prevented by court action from developing and operating a hatchery complex upon the site because of the lack of a water right (Cearheard).

One mile downstream from the old Trout Lodge Hatchery, a new hatchery was built by E\&l McEeary. The contractor understand 6 that the court's concern over degradation of the water supply upstream of McLeary operation prevented WDG from developing it own fish culture program.

Collin Shane Hatchery.

A spring water supply of 10 to 15 cfs located seven miles north of Moses Lake is used by a private owner, Co1 lin Skane of Moses Lake, to supply a medium-sized rainbow hatchery.

Mr. Skane formerly worked at the Trout Lodge facility (kocky FordCreek). About eight years ago he began developing his own site. He related that his rainbow production (kamloops variety) is mainly sold in Canada and that his station is certified to be disease free, with a slightly warmer temperaturethan the 53 -degrees-P water at Trout Lodge. Mr. Skane has applied for a water right on his spring and now appears to be awaiting approval by the Washington Department of Ecology. The contractor considers him to be very knowledgeable about trout culture.

Mr. Shane also reported that a second spring exists one and one-half to the miles north on state property. This spring flows at about five cfs and it could supplya satellite to this station.

Kocky Reach (Turtle Rock).

The Kocky Reach fish facilities are located on Turtle rock Island in the Kocky Reach Chelan County PUD reseroir approximately 1.5 miles upstream from the dam. The existing fish facilities were constructed and are now maintained by the Chellan County PUD but they arc operated by WDF.

Regarding the facilities, the contractor supports the pond modification concept at Turtle Rock designed by CH2M Hill. Present water quality at this station, however, is m a rginal (Antipa, 1980).

Turtle Rock has a pumping capacity of 15 cfs from each of four pumps, or 60 cfs of surface water from the reservoir (Entiat Lake) for the fish facilities. Only half of this water and half of the facilities are used. MR. ilauck informed the contractor that a test well was to be immediately drilled on the island in hope of intercepting an aquifer and eventually leading to the development of 20 cfs of ground water. 
Kocky $\underline{\text { Keach Annex. }}$.

Kocky Keach Annex fish facilities are located immediately downstream of the Kocky Keach Chelan County PUD Dam on the left bank of the Columbia River. Existing fish facilities are maintained and owned by the Chelan County PUD and operated by WDF.

Messrs. Hauck, Leman, and Hays of Chelan County PUI) informed the contractor that approximately 10 cfs of toe drain water exists on the left bank immediately downstream of Kocky Keach Dam. Four cfs of this water is now in use, and plans are in progress to develop the additional six cfs (Hauck).

Leavenworth National Fish Hatchery Expansion.

The Leavenworth NFH is located three miles southwest of the town of Leavennworth along the left bank of Icicle Kivrr. The present complex is supplied with water from Icicle Kiver and six shallow wells.

Based on the success in obtaining water from the existing wells, the contractor believes an additional $10 \mathrm{cfs}$ could be obtained similarly. In addition, up to 30 to 550 cfs of Icicle Kiver water could be obtained from March through Play from an abandoned adult holding area.

Entiat Natinal Fish Hatchery Expans $\underline{\text { sion. }}$.

The Entiat National Fish Hatchery is located on the right bank of the Entiat River sevenmiles upstream from its confluence with the Columbia Kivet. It is supplied with water from a small spring:, wells, and the river. Further development of ground water does not appear feasible.

From March through June of each year, up to 30 cfs of additional Entiat Kiver water can be delivered by gravity through an existing unused 30 -inch steel pipeline. The contractor recomorends that several one-half-acre ponds be developed to use this additional river water.

Well Salmon and Trout tlotchery Expansion.

The Wells Salmon fish facilities are located immediately downstream of the Douglas County PUD Dam on the right bank of the Columbia Kiver. The fish facilities were constructed by the PUD. They are responsible for maintenance, but WDF and WDG conduct the operations.

Confusion exists on the amount of well water availahale at the Well Hatchery. Mike Erho biologist for the Douglas County PUI) reports their inflow meters show up to $18 \mathrm{cfs}$, while both agencies believe the amount coming A - 19 
into the pond is far less - more like ten cfs. The PUDs and agencies should determine the actual volume available.

Kiver water is supplied to the facilities by a gravity flow siphon from Wells Dam (Lake Pateros). The siphon's capacity is estimated at 142 cfs (Erho), with less than 30 cfs being used in the present rearing program. Additional reservoir water is therefore available for fish rearing programs without siphon modifications. Since the siphon is simple and the capital investment has already been made to complete the water delivery system and supporting fish facilities, continued utilization and expansion of facilities appears to he very worthy of consideration.

\section{Winthrop National Fish Hatchery Expansion.}

The Wintrop National Fish Hatchery Is located on the right hank of the Methow Kivcr one mile from the town of Winthrop. Evidence suggests that ground water in the vicinity of the town is abundant. W.M. Chapman in 1938 reported to B.M. Brennan, Director of $W F<$ on the potential hatchery sites in the upper Methow Valley. Five springs were documented in this area: Upper More's Spring; Lower More's Spring; Auto Park Spring, Schaefer's Place Spring; and Foghorn Springs. The latter is the present hatchery site. Sill Wallien, manager at Winthrop KFH, informed the contractor of two large springs approximately six miles upstream of his station. These springs aresimilar in size to Foghorn Springs.

The Winthrop NFH site has a developed infiltration gallery that can deliver 10 cfs of water at 49 degree $F$. The lift is approximately 14 feet and pumping equipment is needed to make the gallery functional. Additional surface water (30 cfs or more) is available from the river; however, the ditch to the hatchery would have to be enlarged.

The contractor's engineer judged that within a reasonable distance of the existing infiltration galleries additional galleries could be developed to produce an additional $10 \mathrm{cfs}$ of 49 -degrees-F water with a low head lift. The area between Winthrop and Twisp also is thought to have good potential for shallow aquifers with abundant water supplies.

\section{$\underline{\text { Methow Kiver }}$ Net Pen Sit e.}

Establishment of a pen site is recommended at the mouth of the Methow Kiver where it enters Lake Pateros upstream from Highway 47 . The quiet forcbay water at this location appears suitable for new pen rearing. The cont ractor proposes that pens be used in small numbers at first to further test the suitability of the site. Steel head production would be recomende from March to May, when smolt release would occur.

$$
\text { A- } 20
$$


Two pens would have the effect of making three cfs of additional water available from Harch through llay at production hatcheries and also would free rearing space. Use of pens during the frozen period would not be recommended.

$\underline{\text { Chief Joseph Hatchery }}$

The proposed Chief Joseph Hatchery would be located immediately downstream from the Corps of Engineers' Chief Joseph Darnon the right hank of the Columbia River.

The hatchery has the quality and quantity of water to allow this site to be listed as potentially good. The proximity to bridgeport presents advantages in living conditions for employees. The sol type and topography are suitable for construction.

The water supply could be fromthreesources: Chief Joseph Dam's toe drain water collected in an infiltration gallery along the north river bank with a minimum 22 cfs water available, (2) a possible five cfs of water available from well field development along the north bank, (3) and unlimited river water (Koch and Cochran, $1977)$.

Nes Perce Fish Production Facility.

The US Fishand Wildlife Service has conducted several studies for Indian tribes to determine potential for anadronous fishproduction on Indian lands. The NezPerce Tribe of Idaho requested a survey of the Clearwater River, the major stream flowing through the Nez Perce Reservation. The conclusion in the report by the US Fish and Wildlife Service is that all the surface waters investigated within the study area were found to have characteristics making them inadequate for a perennial rearing program under the study criteria (US Department of the Interior, Fish and Wildlife Service, September, 1980).

llowever, spring water at old Hatchery Springs along Lapwai Creek met the site criteria of the Fish and Wildlife Service. Water chemistry of the springs indicated that dissolved lead concentrations and filterable residue were near the upper limits for anadronous fish rearing. Water quantity ranged from a summer low of. 5 cubic feet/second to $3.2 \mathrm{cubic}$ feet/second in the winter. At this site Idaho State Fish and Caine Department began to construct a rearing facility in the lyou's. The facility was not completed and never operated. A concrete raceway was constructed and could be utililzed. 
Umatilla Indian Reservation Study.

The US Fish and Wildlife Service also conducted an anadromous fish enhancement study on the Uma ti 1 la Indian Reservation on behalf of the Confederated Tribes of the Umatilla Indian Reservation (US Department of the Interior, Fish and Wildlife Service, August, 1960). Upon evaluation of the data and associated operating costs developed during this study, Minthorn Springs and Bonifer Springs sites were the areas recommended as most economically feasible for fish production facilities on the Reservation.

The Minthorn Springs hatchery site is located on private land along the bank of the Umatilla River at river mile 05.4. Development is restricted by the quantity of water available and the limited hydraulic head. The Service estimated that for a single species only, not cumulative, the facility could produce 95,000 steellhead smolts, 49,000 spring chinook smolts,64,000 fell chinook smolts, or 49,000 coho smolts.

The Bonifer Springs hatchery site is located on private land along the bank of Meachem Creek1.5 miles upstream from its confluence with the Umatilla River Estimated production levels are based on the entire available flow and a single pass facility. smolt production figures for a single species only, not cumulative, are as follows: steelhead, 146,000 ; spring chinook, 69,000; fall chinook,100,000; or coho 93,000 .

As a result of these studies the Bonifer springs facility was completedin 1983 and Minthorn Springs is now under construction.

Yakima Indian Reservation Klickitat River $\underline{\text { Hatchery }}$.

In 1978 and 1979 the US Fish and Wildlife Service conducted an anadromous fish enhancement study of the Klickitat River system on behalf of the Yakima Indian Tribe (US Department of the Interior, Fish and Wildlife Service, December 1979). Field investigations were confined to the watershed within the confines of the Yakima Indian reservation. All surface waters within the study area had characteristics making them inadequate for perennial rearing. However, two excellent spring water supplies within 1,000 feet of each other were investigated. Cascade Springs is located on the west side of the Klickitat Kiver about 1,000 feet north of Outlet Creek. A conservative estimate of the flow is 20 cfs. Outlet Creek has several springs which enter the creek in the last mile of the stream above it confluence with the Klickitat Kiver. Flow f rom these springs total about $80 \mathrm{cfs}$. The water temperature of the springs averages 43 to 45 degrees F. Estimated smolt production for a single species on.l., not cumula tive is as follows: steelhead, 2,100,00; spring chi nook, 4,200,000; 
fall chinook, 6,00.0O; or coho 5,700,000.

In addition to the Klickitat study, the Confederated Tribes and Bands of the Yakima Indian Nation have expressed interest in a number of other hatchery facility sites. In response to an inquiry from Gala, the Yakima Indian Nation sent the following list of such sites.

\section{$\underline{\text { Potential Hatchery Facility Sites }}$}

I. Adult Trapping

A. Prosser Division Dam - right bank ladder

B. Roza Division Dam - ladder

c. Cowiche Diversion Dam - ladder

I I Adult Holding; Egg Incubation; Pond/Raceway Kearing

A. WUC Yakima Trout Hatcher5y (Yakima Airport)

I). Buckski $\mathrm{n}$ C reek (Naches $\mathrm{Ri}$ ver)

c. Nile Pond ( $\mathrm{near} \mathrm{Kattlesnake} \mathrm{Creek)}$

D. Naches trout farm (commercial facility) (Naches Kiver)

E. Cle Elum Hiver (below dam)

F. WL)S Naches Trout ilatchery (Naches Kiver)

G. Union Cap ponds

H. Outlet Springs (Klicki tat Kiver)

I . Upper Satus Creek

J. Toppenish Creek (Dan Olney's

K. Simcoe Creek (near guard station)

L. Lost Creek (Naches Kiver)

I I . Net Pen Kearing

1. Gravel pits - Baston to Cle Elum

2. Gravel pi t s - Sclah to Yakima

3. Crave 1 pits - lower basin

4. Gravel pits - Union Cap

5. Keservoir - Cle Elum

b. Kese rvoi $r$ - Keeclielus Dam

7. Ke s e r voir - Kacheso

8. Keservoir - Rimrock

9. Keservoi $r$ - Bumping

IV. Other Kearing Sites

1. Oxbow ponds - Yakima Keservat ion below Sunnyside Dam

2. Pasco NMFS raceways.

No other supporting information was sent with the preceding lis t . 
Potential Hatchery Site Information from State pishery Agencies.

The state fisheries agencies of oregon, Washington and Idaho have obtained some information regarding potential hatchery sites. The files of the Oregon Department of Fish and Wildife dating from the early ly70's yielded the following information.

\section{OREGON DEPARTMENT OF FISHERIES AHD WILILIFE}

Late

1985

1984

1981

1980

1977

1976

1975

1974 Site kiemarks

ODFW is presently looking for sites to set up egg incubation facilities to solve virus problems

Chinook and silver salmon raised since 1978; for sale or lease; 15 wells, 4-y, 000 gpm, 51-53 degrees summer to spring, 10 concrete circulars, 1 conc. raceway, 11 Doughboy swimming pools with conc. bottoms, l vinyl lined pond.

Proposed steelhead facility, as part of the Lower Snake kiver Compensation Program
Crooked Kiver Hatchery lienge Salmon Private Farm, Corvallis, OK
Lower Snake River Compensation Plan:

Lostine-Wallowa site No. 1: no further study (nfs); water probleins (wp).

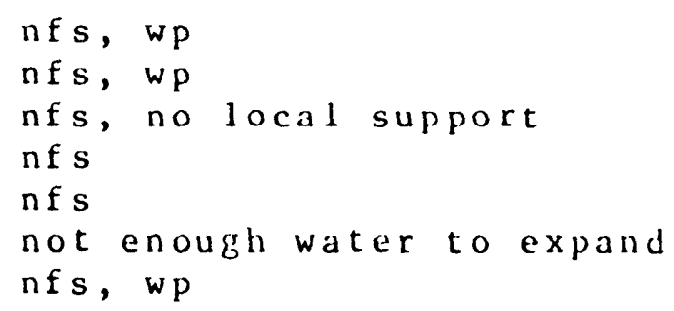

5,000 gpm spring, 53 degree all year
Spring-fed streams: iोig Creek, Lake Creek, Sumult Creek

Kearing pond, spring chinook

Arra Wanna Éstates

1 mid. $N$ of welches

Salmon River, Sandy system
Harmot Pond, Sandy
Water problems
Kiver, Old Sandy
River llatchery
Further study 
The Oregon files also mention the potential for ground water in the Portland area to produce from 2-4 million coho salmon smolt.

The Washington State Department of Game reports an interest in the following potential hatchery sites in the Columbia River system.

1. Ellsworth Springs: This site is located east of Vancouver near the WDC Vancouver hatchery. This spring water site may have potential for a small hatchery. The site is owned by the City of Vancouver.

2. Stimson Flat: This site on the Klickitat River has potential for an imprinting pond. WDC owns the site. Water would have to be diverted from the Klickitat Kiver.

3. Kockly Ford Creek: This site has potential if differences with a downstream private grower can be ironed out. WL)G own this site near Ephrata.

4. Waikiki Springs: This site north of Spokane is owned by WDG. WDG hopes some day to develop a trout hatchery here. There may be space and water for anadromous production as well.

The response of the Washington State Department of Fisheries to inquiries was that the Department has made no recent surveys for potential hatchery facilities in the Columbia River system.

The Idaho Department of Fish and Game has made extensive surveys for new anadroarous fish hatchery sites with little success. The Warm Kiver site has 2 U 0 cfs of 52 degree spring water. These springs are near Ashton and the Warm River is a tributary of the Henry's Fork of the snake Kiver. Smolts would have to be transported about $15 \mathrm{U}$ miles for access to the ocean. Winter access to the site is difficult and the road would have to be improved and kept open during heavy winter snows.

Several private commercial hatcheries in Idaho have potential for rearing anadromous species but would require purchasing the present operations. 
TABE A3. I ESTIKATION OF THE POTENTIAL ANADROMOUS FISH PRODUCTION FROK

STIES IDENTFED IN IDAHD ORECON AND WASHNGTON STATES.

ESTIMATES ARE BASHDUPON8 LB/GPM AT HINIMUM RON.

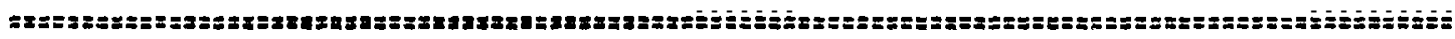

POIENTIAL HATCHVALABLE FLOH OFS AVALABLE fLOH (GPH) TOTAL FLON ESTIMATE OF PROUCTON

SITES SURFACE GOND SUPFACF GROND (GPM) BASEDLPONB LB/GPN

IN IDAHD

BANABURY SPRNG

HALAD SPRINGS

THQSANDSPRNGS

100

110

SANDSPPINGS

BRIG65 SPRINGS

AICKEL SPRING

BLLE SPRINGS

BOX CANYON SPRING

BUE LAKES SPRINS

QEAR LAKE SPRINGS

NIAGARA SPRINGS

RYSTAL SPRNGS

1000

80

105

NODATA

60

IN USE

IN USE

IN USE

IN USE

INUSE

DEMLS CORRAL SPRINGS NO SITE

JEROME AREA WBIS

SHOSHONE AREA IUS

HNDOKAPAL AREA

MUD LAKE AREA

REXBURG AREA

HAMILTON SPRINGS

PRVATE 0

BIROH R⿴囗十 70

816 SPRINGS (LEADORE) 25

PAHSIMEROI GQONDHATRR 25

HERYS FORK ARE TOOREMOTE FROH

GHШY SINKS- KACKAY RES. NODATA

BG SPRING CR⿴囗十

25

SNAKE WHIS NEAR REXYURG

50

748
822.8 822.8b502.4
$740 \quad 5904$
$7480 \quad 7400 \quad 59040$
$598.4 \quad 598.44707 .2$
$105.4 \quad 705.4$ b203.2

448.8

448.83590.4

00

$0 \quad 0$

$0 \quad 0$

$0 \quad 0$

$0 \quad 0$

$0 \quad 0$

$374 \quad 374 \quad 2992$

$374 \quad 374 \quad 2992$

$299.2 \quad 299.22393 .6$

$\begin{array}{lll}374 & 374 & 2992\end{array}$

$\begin{array}{lll}374 & 374 & 2992\end{array}$

$\begin{array}{lll}0 & 523.6 \quad 4100.0\end{array}$

$\begin{array}{lll}107 & 187 & 496\end{array}$

$187 \quad 187 \quad 1496$

$0 \quad 0 \quad 0$

$\begin{array}{lll}187 & 107 & 1496\end{array}$

$374 \quad 374 \quad 2992$ 
TABLE A-3.2 ESTIMATION OF THE POTENTIAL ANADROMOUS FISH PRODUCTION FROH SITES IDENTIFIED IN IDAHO, OREGON, AND WASHINGTON STATES. ESTIMATES ARE BASED UPON 8 LB/GPM AT HINIMUM FLOH.

\begin{tabular}{|c|c|c|c|c|}
\hline POTENTIAL HATCHAVAILABLE & FLOW CFS & AVAILABLE FLOW (GPM) & TOTAL FLON & ESTIMATE OF PRODUCTION \\
\hline SITES SURFACE & GROUND & SURFACE GROUND & (GPM) & BASED UPON 8 LB/GPH \\
\hline
\end{tabular}

\section{IN OREGON} UPPER GRANDE RONDE NO DATA MINTHORN SPRINGS BONIFER SPRINGS THORN HOLLON SPRINGS GENGE SALMON FARH CROOKED RIVER HATCHERY NO DATA OPAL SPRINGS SNIPE CREEK VAN HULLIEN RANCH PORTLAND AREA NELLS

NO DATR

$\begin{array}{rrrrr}1.3 & 0 & 9.724 & 9.724 & 77.792 \\ 1.5 & 0 & 11.22 & 11.22 & 89.76 \\ 0.45 & 0 & 3.366 & 3.366 & 26.928 \\ & 0 & 4000 & 4000 & 32000\end{array}$

NO DATA

NO DATA

NO DATA 
TABLE A-3.3 ESTIMATION OF THE POTENTJAL ANADROMOUS FISH PRODUCTION FROM SITES IDENTIFIED IN IDAHD, OREGON, AND WASHINGTON STATES. ESTIMATES ARE BASED UPON 8 LB/GPM AT MINIMUH FLOW.

\begin{tabular}{|c|c|c|c|c|c|c|}
\hline \multicolumn{3}{|c|}{ POTENTIAL HATCHAVAILABLE FLOH CFS } & \multicolumn{2}{|c|}{ AVAJLABLE FLOW (GPM) } & \multirow{2}{*}{$\begin{array}{l}\text { TOTAL FLOH } \\
\text { (GPH) }\end{array}$} & \multirow{2}{*}{$\begin{array}{l}\text { ESTIKATE } \\
\text { BASED UPO }\end{array}$} \\
\hline $\begin{array}{l}\text { SITES } \\
z=:=:=:=:=:\end{array}$ & $\begin{array}{l}\text { SURFACE } \\
\text { :U: }\end{array}$ & $\begin{array}{c}\text { GROUND } \\
=x=x=x=x=x\end{array}$ & $\begin{array}{l}\text { SURFACE } \\
=:= \pm:=3:= \pm\end{array}$ & $\begin{array}{l}\text { GROUND } \\
=:=:=:=:=:=:\end{array}$ & & \\
\hline \multicolumn{7}{|l|}{ IN HASHINGTON } \\
\hline PASCO DRAIN & & 60 & 0 & 448.8 & 448.8 & 3590.4 \\
\hline RINGOLD DITCH & & 20 & 0 & 149.6 & 149.6 & 1196.8 \\
\hline PRIEST RAPIDS H & 50 & 17 & 374 & 127.16 & 501.16 & 4009.28 \\
\hline \multicolumn{3}{|c|}{ RICHLAND CANAL NO DATA } & 0 & 0 & 0 & \\
\hline BARKER POND & 1 & & 7.48 & 0 & 7.48 & 59.84 \\
\hline HORSESHOE POND & 20 & & 149.6 & 0 & 149.6 & 1196.8 \\
\hline RICHLAND POND & 6.7 & & 50.116 & 0 & 50.116 & 400.928 \\
\hline CIONA CANAL & 15 & & 112.2 & 0 & 112.2 & 897.6 \\
\hline AHTANUK & 6 & & 14.88 & 0 & 44.88 & 359.04 \\
\hline WIDE HALLOW CRE & 3.6 & & 26.928 & 0 & 26.928 & 215.424 \\
\hline NILE SPRIN6 & & 3 & 0 & 22.44 & 22.44 & 179.52 \\
\hline NACHES HATCHERY & & 1.1 & 0 & 8.228 & 8.228 & 65.824 \\
\hline TIETON DAM SPRII & & 0.75 & 0 & 5.61 & 5.61 & 44.88 \\
\hline GOLD CREEK & NO FLOW I & N WINTER & 0 & 0 & 0 & \\
\hline HILDCAT CREEK & 12 & & 1.76 & 0 & 89.76 & 718.08 \\
\hline NELSON SPRINGS & 7 & & 2.36 & 0 & 32.36 & 418.88 \\
\hline CLE ELUH PONDS & 30 & 5 & 224.4 & 37.4 & 261.8 & 2094.4 \\
\hline CLE ELUN PITS & & 10 & 0 & 74.8 & 74.8 & 598.4 \\
\hline EASTON PONDS & 20 & 2 & 149.6 & 14.96 & 164.56 & 1316.48 \\
\hline TJOSSEN POND & & 2 & 0 & 14.96 & 14.96 & 119.68 \\
\hline SHEA CREEK & 10 & & 74.8 & 0 & 74.8 & 598.4 \\
\hline UNMAMED CREEK & 0.85 & & 6.358 & 0 & 6.358 & 50.864 \\
\hline MANASTASH CREEK & 1.5 & & 11.22 & 0 & 11.22 & 89.76 \\
\hline PARKE CREEK & 3.5 & & 26.18 & 0 & 26.18 & 209.44 \\
\hline CARIBOU CREEK & 2 & & 14.96 & 0 & 14.96 & 119.68 \\
\hline COLEMAN CREEK & 2 & & 14.96 & 0 & 14.96 & 119.68 \\
\hline NANUH CREEK & 1.5 & & 11.22 & 0 & 11.22 & 89.76 \\
\hline UNNAHED SPRING & 4 & & 29.92 & 0 & 29.92 & 239.36 \\
\hline UATANUM CREEK & 3 & & 22.44 & 0 & 22.44 & 179.52 \\
\hline WILSON CREEK & 1.5 & & 11.22 & 0 & 11.22 & $89.7 t$ \\
\hline
\end{tabular}


TABLE A-3.4 ESTIMATION OF THE POTENTIAL ANADROMOUS FISH PRODUCTION FROM SITES IDENTIFIED IN IDAHO, OREGON, AND WASHINGTON STATES. ESTIMATES ARE BASED UPON 8 LB/GPM AT HINIMUH FLOW.

\begin{tabular}{|c|c|c|c|c|c|}
\hline $\begin{array}{l}\text { POTENTIAL HATCHAVAILABLE } \\
\text { SITES SURFACE }\end{array}$ & $\begin{array}{l}\text { FLOH CFS } \\
\text { GROUND }\end{array}$ & $\begin{array}{l}\text { AVAILABLE } \\
\text { SURFACE }\end{array}$ & $\begin{array}{l}\text { LOH (GPM) } \\
\text { GROUND }\end{array}$ & $\begin{array}{l}\text { TOTAL FLOH } \\
\text { (GPM) }\end{array}$ & $\begin{array}{l}\text { ESTIMATE OF PRODUCTION } \\
\text { BASED UPON } 8 \mathrm{LB} / \mathrm{GPH}\end{array}$ \\
\hline 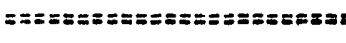 & $y=32 x=2=3 x z$ & $z=25 x=3 z z=0$ & $z=z=z=x=z=2$ & z=z:=:=z=:s=z & 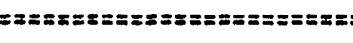 \\
\hline \multicolumn{6}{|l|}{ WASHINGTON (CONTINUED) } \\
\hline COLOCKUH CREEK & & 14.96 & 0 & 14.96 & 119.68 \\
\hline ROCKY FORD CREE & 50 & 0 & 374 & 374 & 2992 \\
\hline COLLIN SHANE & 10 & 0 & 74.8 & 74.8 & 598.4 \\
\hline \multicolumn{6}{|c|}{ SEEP LAKES SPRINO DATA NO DATA } \\
\hline DRAIN 239 (QUINCY) & 10 & 0 & 74.8 & 74.8 & 598.4 \\
\hline DRAIN WELL (D-86-1) & 6 & 0 & 44.88 & 44.88 & 359.04 \\
\hline DRAIN WELLS $1,2,4,5$ & 9 & 0 & 67.32 & 67.32 & 538.56 \\
\hline LOWER CRAB CREEK & 15 & 0 & 112.2 & 112.2 & 897.6 \\
\hline TURTLE ROCK & 10 & 224.4 & 74.8 & 299.2 & 2393.6 \\
\hline ROCKY REACH ANNEX & 6 & 0 & 44.88 & 44.88 & 359.04 \\
\hline $\begin{array}{l}\text { ROCK ISLAND CRENO DATA } \\
\text { DOUGLAS CREEK NO OATA }\end{array}$ & \multicolumn{4}{|c|}{ DOUGLAS CREEK NO OATA } & \\
\hline DRYDEN POWER CA & & 561 & 0 & 561 & 4488 \\
\hline SCHAITTEN POND & 2 & 0 & 14.96 & 14.96 & 119.68 \\
\hline LEAVENWORTH NFH & 10 & 224.4 & 74.8 & 299.2 & 2393.6 \\
\hline ENTIAT NFH & & 224.4 & 0 & 224.4 & 1795.2 \\
\hline WELLS HATCHERY & & 748 & 0 & 748 & 5984 \\
\hline CHELAN TROUT HATCHERY & 12 & 0 & 89.76 & 89.76 & 718.08 \\
\hline WINTHROP NFH & 10 & 224.4 & 74.8 & 299.2 & 2393.6 \\
\hline METHOH RIVER PE & & 29.92 & 0 & 29.92 & 239.36 \\
\hline \multicolumn{6}{|l|}{ PATERDS KATCHERNO DATA } \\
\hline CHIEF JOSEPH DAK & 27 & 0 & 201.96 & 201.96 & 1615.68 \\
\hline CASCADE SP/OUTLET CRK & 100 & 0 & 748 & 748 & 5984 \\
\hline ELLSHORTH SPRIN & NO DATA & & & & \\
\hline
\end{tabular}


Appendix B

Full production and costs of required modifications 


\section{$\underline{\text { Standard Calculation to Achieve Full Production }}$}

Full production was estimated using the "flow"--e.g. weight of fish per gallons per minute (GPM) of inflow, and "density"-weight of fish per cubic foot of pond volume. The formula for the" f 1 ow "estimation procedure is $P=F \times L \times G$ as described in the Methods and Materils section. The load factors (F) used are from tables in Bell (1973) and Piper et al. (1982) are a function of water temperature ( 55 degrees farenheit) and altltude.

The formula for the "density" estimation proceedure was after the formula in Piper et al. (1982), e.g., $\mathrm{D} \quad-\quad \begin{array}{llllllll}.5 & \mathrm{X} & \mathrm{L} & \mathrm{X} & \mathrm{V}\end{array}$ A range of full production levels was developed based upon agency production goal statements (Lower Snake River Fish and Wildlife Compensation Plan 1983) of .8 pounds per cubic foot (WDF) and 2 pounds per cubic foot (IFG and USFWS). The formula for the full production estimation was $P=D X V$. The use of the density range of from .8 t.o 2 pounds per cubic foot provides a usable range of production density goals that are useable (densities in excess of 1 pound percubicfoot is considered excessive and probably detrimental to anadromous salmonids). Actual production estimates were based upon pounds released and represent a pounds per cubic foot per year figure. Production at the Columbia River Basin facilities examined in this project ranged from 2.36 pounds per cubic foot at 
Abernathy National Fish Hatchery to 0.02 pounds per cubic foot at +the Ringold Steelhead rearing facility. During the three year period examined, an average of 6.1 million pounds of anadromous salmonids were released from Columbia Basin facilities with a rearing volume of 33.5 million cubic feet. This represents an average annual actual production at release of 0.18 pounds per cubic foot. Actual rearing space is 35.7 cubic feet. Several new facilities were comming on line during this project and a number of facilities produce resident fish in part or in total ( Table B - 1.0).

The reasons for the great differences in densities at release for the facilities included the limitations imposed by water quantity and quality, differences in agency policy on rearing density, density reductions due to disease, predation or other natural mortality factors, and limits to available eggs (specifically spring and summer chinook stocks). In a number of cases non-endemic stocks were subjected to rearing conditions that resulted in low production potential (high mortality due to disease, high temperature extremes, etc.). Disease resulted in the total or partial loss of several years of production at several of the facilities. Mortality among adult spring chinook was extremely high at all facilities resulting in 30 to $50 \%$ mortalities prior to spawning, and significantly reducing spring chinook smolt production potential.

Estimates of full production are provided for each facility of interest in the Columbia River Basin, and can be found in Table A-2.0 for potential sites and in Table B-1.0 - under various density related criteria (Piper et al (1982) density, 
Piper et al. (1982) flow, 0.8 pounds per cubic foot and 2.0 pounds per cubic foot density range). A form was filled out for each facility with pertinent data that led to the full production estimate(s), additlonal facilities or means of achieving full production, and capital and O\&M estimates were provided where pertintent. 


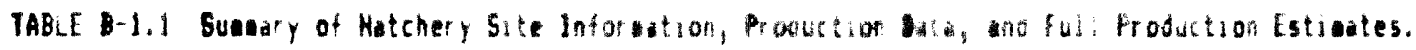

\begin{tabular}{|c|c|c|c|c|c|c|c|c|c|c|}
\hline \multirow{3}{*}{$\begin{array}{l}\text { MAICHERY } \\
\text { MAME }\end{array}$} & \multirow{3}{*}{$\begin{array}{l}\text { FLON } \\
\text { ICFS }\end{array}$} & \multirow{3}{*}{$\begin{array}{l}\text { VOLUWE } \\
\text { ICF! }\end{array}$} & \multicolumn{8}{|c|}{ PROOUCTIOA } \\
\hline & & & \multicolumn{3}{|c|}{ ACYAL AUERAES } & \multicolumn{5}{|c|}{ SYINAIL } \\
\hline & & & $F I S H / L B$ & LB/ TEAR & SPE IES & PERCEN & DENSIT & Flon & $.8 \mathrm{lB} / \mathrm{CF}$ & $3.01 \mathrm{~B} / \mathrm{CR}$ \\
\hline I ABERNATHY & 240 & 17,280 & 42.99 & 40,800 & P.CH. & 100 & 40,800 & & 13,800 & 34,600 \\
\hline 2 ALDER CRK PND & Mo & 306,000 & 5.0 & 15,930 & W. S?. & 100 & 15,930 & & 308,800 & 7,720 \\
\hline \multirow[t]{2}{*}{3 BEAVER CRK } & 13 & 125,695 & 5.8 & 11,200 & $5 . C H$ & 10. & 107.850 & & 100,600 & 251,400 \\
\hline & & & 8.3 & 76,650 & 1.5 & 89.6 & & 61,915 & & \\
\hline \multirow[t]{4}{*}{$4816 \mathrm{CRK}$} & 51.3 & 144,000 & $6 . ?$ & 11,400 & Y.S? & 1.4 & & & & \\
\hline & & & 2.9 & 1,967 & $\$ . C T$ & 1.3 & & & & \\
\hline & & & 72.3 & $B 3,170$ & F.CX. & 34.2 & 154,037 & & & \\
\hline & & & 16.5 & 57,200 & СОНО & 37.1 & & $163,05 ?$ & 115,200 & 88,000 \\
\hline 5 DI6 UHT SALHOK & 47.1 & 11.920 & WO DATA & & ${ }^{5} \mathrm{CH}_{\mathrm{O}}$ & & & & 11,000 & 17.800 \\
\hline \multirow{2}{*}{ D BONNEVILLE } & 45.7 & 299,384 & 40.1 & 238,194 & $\mathrm{~F} . \mathrm{OH}$ & 35. & $24,21 \%$ & & & \\
\hline & & & 19.2 & 126,022 & 60 & 34.5 & & $140,18\}$ & 239,500 & 98,800 \\
\hline \multirow[t]{2}{*}{7 CASCADE } & 35 & 22,050 & 33.1 & 16,104 & F.CH. & 37.0 & 44,303 & & & \\
\hline & & & 65.8 & 27,899 & to & $\$ 3.0$ & & 92.758 & 68,900 & 172,200 \\
\hline \multirow{4}{*}{9 CONLIII SAL. } & $34-1$ & 144,320 & 7.1 & 143,078 & B.CH. & 100.0 & 143,078 & 176,103 & 115,500 & 288,600 \\
\hline & 167 & 222,720 & 19.8 & 202,121 & 00 & 42.9 & & & & \\
\hline & & & 76.1 & 153,208 & $5 . \mathrm{Cl}$ & 32.5 & 470,779 & & & \\
\hline & & & 27.4 & 115,450 & SP.CH. & 24.5 & & 513,357 & 593,3001 & $1,483,200$ \\
\hline \multirow[t]{2}{*}{ IO CONLITI TROUT } & 61 & 747,000 & 9.2 & 19,071 & S.CT. & 13.1 & & & & \\
\hline & & & 16.4 & 24,777 & $S . S T$ & 46.9 & 146,133 & & & \\
\hline 11 REARING PONDS & & & 9.3 & 102,285 &.$S T$ & 69.9 & & 267,112 & $597,600 \quad$ & $1,494,000$ \\
\hline \multicolumn{11}{|l|}{12 DEER SPRINGS } \\
\hline \multirow[t]{3}{*}{13 EAGLE CREEK } & 78.1 & 120,000 & 12.8 & $15,918.5$ & $5 !$ & 43 & 170.127 & & & \\
\hline & & & 18.2 & $31,560.6$ & $c$ & 42.9 & & 301,137 & 96,000 & 240,000 \\
\hline & & & 12.9 & 52,640 & $\$ F, C H$ & 43.8 & & & & \\
\hline \multirow[t]{2}{*}{14 ELKOHIN } & 44.65 & 278,800 & 22.7 & 143,000 & $c 0$ & 83 & & & & \\
\hline & & & 91.7 & 29,400 & $5 . \mathrm{CH}$ & $1 ?$ & & 120,134 & 223,000 & 557,60 \\
\hline \multirow[t]{3}{*}{ I5 GNAT CREEK } & 1.23 & 96,000 & 6.9 & 32,435 & 5.57. & 34.7 & & & & \\
\hline & & & 6.5 & 60,516 & V.5T. & 64.7 & 93,624 & & & \\
\hline & & & 1175 & 673 & $c 0$ & 0.7 & & 8,197 & 76,800 & 192,000 \\
\hline \multirow[t]{2}{*}{ I6 TROJAN PONO } & 6.6 & 28,800 & 5.0 & 25,44 & 5.57 & 1981 & 21550 & & & \\
\hline & & & 15.6 & 17.660 & $\mathrm{CO}$ & 1982 & & 31,076 & 23,000 & 57,600 \\
\hline \multirow[t]{2}{*}{17 GOBAR PONO } & 4.9 & 518,400 & 5.2 & 12,986 & 5.51 & 51.7 & 25,132 & & & \\
\hline & & & 5.2 & 12,146 & W.Si & 18.3 & & 27,027 & $\$ 14,700$ & \\
\hline \multirow[t]{2}{*}{18 GRAYS $R$. } & 10 & 74,350 & 96.3 & 21,78 & F.CH & 50.7 & 42,940 & $(43,285)$ & & \\
\hline & & & 18.9 & 21,158 & $\mathrm{CO}$ & 49.3 & & $28,85 ?$ & 95,900 & 239.900 \\
\hline is Meriu füNu & & $, 001,860$ & 90.1 & 44,893 & f.ly & & 44,893 & & 801,500 & \\
\hline
\end{tabular}




\begin{tabular}{|c|c|c|c|c|c|c|c|c|c|c|}
\hline \multirow{3}{*}{$\begin{array}{l}\text { HATCHERY } \\
\text { aAHE }\end{array}$} & \multirow{3}{*}{$\begin{array}{l}\text { FLOY } \\
\text { (CFS) }\end{array}$} & \multirow{3}{*}{$\begin{array}{l}\text { VOLLAHE } \\
\text { (CF) }\end{array}$} & \multicolumn{8}{|c|}{ Production } \\
\hline & & & \multicolumn{3}{|c|}{ ACTUAL AYERAGE } & & & \multicolumn{2}{|c|}{ ESYIAATE } & \multirow[b]{2}{*}{$2.0 \mathrm{LB} / \mathrm{CR}$} \\
\hline & & & FISH/LB & IB/VEAC & SPECIES & PERCENT & DEMSITY & FLON & $.8 \mathrm{LB} / \mathrm{CF}$ & \\
\hline \multirow[t]{3}{*}{20 KALAKH FALIS } & 613.37 & 334,640 & 14.5 & 20,438 & $\mathrm{BF}, \mathrm{CH}$ & 27.8 & & & & \\
\hline & & 134,640 & 35.4 & 52,050 & F.CH & 70.9 & 73,466 & & & \\
\hline & & & 1359.0 & 978 & $\mathrm{COHO}$ & 1.3 & & 44,067 & 107,700 & 269,300 \\
\hline \multirow[t]{4}{*}{21 KLASKANIN } & $2.67-22$ & 236,370 & 15.1 & 117,812 & $\mathrm{COHO}$ & 66.8 & & & 189,100 & 972,700 \\
\hline & & & 81.0 & 45,782 & F.CH. & 26.0 & & & & \\
\hline & & & 510.0 & 1,478 & CH.S & 0.8 & 176,433 & (91292) & & \\
\hline & & & 5.3 & 11,337 & W.5T. & 6.4 & & 77247 & & \\
\hline \multirow[t]{2}{*}{22 LEABURG } & $1.2-1.5$ & 262,045 & 4.9 & 15,950 & का & & 31154 & & & \\
\hline & & & 7.4 & 26,356 & S.ST. & & & 6,127 & 209,600 & 524,000 \\
\hline \multirow[t]{3}{*}{23 LENIS R. } & 14.5 & 325,320 & 17.3 & 245,049 & co. & 74.8 & & & 325,400 & 013,600 \\
\hline & & & 10.6 & 80,054 & $\mathrm{SFCH}$ & 21.1 & 227,508 & & 260,000 & 650,600 \\
\hline & & & $22 t . !$ & 2,405 & $F C A$ & 0.7 & & 564,116 & & \\
\hline \multirow[t]{3}{*}{24 LOMER KALANA } & 18.5 & & 14.0 & 16,285 & SPEN & & & & & \\
\hline & & 92,140 & 23.0 & 78,536 & $\mathrm{COHO}$ & 73.9 & 106,200 & & & \\
\hline & & & 104.7 & 27,676 & F.CH & 26.1 & & 55,998 & 73,900 & 184,800 \\
\hline \multirow{3}{*}{25 MARION FKS } & 17.1 & 85,904 & 12.9 & 21,561 & W.ST & 36.4 & & & & \\
\hline & & & 13.6 & 3,200 & S.ST & 5.4 & 59,285 & & & \\
\hline & & & 35.1 & 34,524 & $\mathrm{SP}, \mathrm{CH}$. & 58.2 & & & 68,700 & 171,800 \\
\hline \multirow[t]{2}{*}{26 NCKENZIE } & 15.6 & 138,600 & 5.9 & 15,703 & S.ST & 11.1 & 141,950 & & & \\
\hline & & & 8.3 & 126,247 & SP.CH. & 88.9 & & 70,582 & 110,800 & 277,200 \\
\hline \multirow[t]{4}{*}{27 MOSSY ROCK } & 2.68 & 42,000 & 89.2 & 533 & $\mathrm{CT}$ & 1.0 & & & & \\
\hline & & & 232.3 & 2029 & 4.57 & & & & & \\
\hline & & & 12.4 & 13,990 & S.CT. & 24.8 & 58,380 & 9733 & & \\
\hline & & & 16.5 & 41,828 & RBW & 74.2 & & $(12166)$ & 33,600 & 84,000 \\
\hline \multirow[t]{3}{*}{28 OXBON (ODFW } & 115 & 67,200 & 40.6 & 48,816 & $\mathrm{CO}$ & 53.3 & & & & \\
\hline & & & 12.2 & 25,018 & SP.CH. & 27.3 & 91,664 & & & \\
\hline & & & 132.99 & 17,830 & F.CH & 19. & & 350415 & 53,800 & 134,400 \\
\hline 29 WAKKENA PND & 5.914, & $4,810,040$ & & & CO & & & & $11,048,000$ & \\
\hline \multirow{3}{*}{$\begin{array}{l}30 \text { HERMAN CRK } \\
31 \text { ROARIING R. }\end{array}$} & 15 & 108,244 & & & & & & 86.6 & 86,600 & 216,400 \\
\hline & $5.9-22.5$ & 597,540 & 7.95 & 25,831 & ע.5T & 63.9 & 40,369 & & & \\
\hline & & 97,537 & 8.2 & 14,538 & S.ST & 36.1 & & $27105 k$ & 78 & 195 \\
\hline & 6.2 & 122,920 & 33.26 & 49,450 & co & & 49,450 & 1804 & 98,000 & 245,800 \\
\hline \multirow{3}{*}{ ЗJ SKALFANIA } & 16.7 & 53,392 & 9.7 & 54,170 & S.ST. & 56.3 & & & & \\
\hline & & & 5.45 & 35,199 & W.5T. & 36.6 & 96,135 & & & \\
\hline & & & 4.99 & 6,766 & $\mathrm{CT}$ & 7.1 & & 805.57 & 42,700 & 106,800 \\
\hline \multirow[t]{2}{*}{34 SO.SANTIAK } & 20.1 & 60,590 & 5.57 & 29,090 & S.ST & 45.7 & & & & \\
\hline & & & 7.78 & 34,542 & SP.CH & 54.3 & 63,632 & 100,374 & 48,500 & 121,200 \\
\hline 35 STAYTON PND & 50 & $3,833,280$ & 76.5 & 81,197 & F.CH. & & 81,197 & 115,986 & $3,066,600$ & \\
\hline
\end{tabular}




\begin{tabular}{|c|c|c|c|c|c|c|c|c|c|c|}
\hline \multirow{3}{*}{$\begin{array}{l}\text { HATCHERY } \\
\text { WAME }\end{array}$} & \multirow{3}{*}{$\begin{array}{l}F(\text { ON } \\
\text { (CFS) }\end{array}$} & \multirow{3}{*}{$\begin{array}{l}\text { VOLUAFE } \\
\text { (CF) }\end{array}$} & \multicolumn{8}{|c|}{ PRODUCTION } \\
\hline & & & \multicolumn{3}{|c|}{ ACTUAL AVERAGE } & \multicolumn{4}{|c|}{ ESTIMATE } & \multirow[b]{2}{*}{$2.0 \mathrm{LB} / \mathrm{CR}$} \\
\hline & & & FISH/LB & LB/YEAR & SPECIES & PERCENT & DENSITY & FLOY & $8 \mathrm{LB} / \mathrm{CF}$ & \\
\hline \multirow[t]{3}{*}{36 SPEELYAI } & $16.52-$ & 80,200 & 31.0 & 73,194 & co & 81.2 & & & & \\
\hline & 23.12 & & 57.4 & 16,031 & $S P . C H$ & 17.8 & 90,102 & $18.77,000$ & 65,800 & 164,100 \\
\hline & & & 961.8 & 877 & F. $\mathrm{CH}$ & 0.9 & & & & \\
\hline 37 TOUTLE & & 324,000 & & & & & & & 259,200 & 648,000 \\
\hline \multirow[t]{3}{*}{38 VANCOUVER } & $2.36-$ & 464,456 & 152.9 & 1,215 & Y.ST & 0.9 & & & & \\
\hline & 4.2 & & 33.9 & 119,333 & S.ST & 98.0 & 121,713 & & & \\
\hline & & & 54.5 & 1,165 & $\mathrm{CT}$ & 0.9 & & $13-23,000$ & 371,600 & 928,900 \\
\hline \multirow[t]{2}{*}{39 WASHOUGAL } & $50.16-$ & 480,000 & 81.06 & 81,310 & F.CH & 46.3 & 175,660 & $127.5-129.7$ & 435,000 & 1087,600 \\
\hline & 51.1 & & 40.41 & 94,350 & $\mathrm{CO}$ & 53.7 & & $255-259,000$ & 3846 & 961,600 \\
\hline \multirow[t]{2}{*}{40 MILLAMETTE } & 45.1- & 268,800 & 57.45 & 74,171 & SP.CH & 76.7 & 96,766 & & & \\
\hline & 33.3 & & 5.47 & 22,595 & S.ST. & 23.3 & & $141-167,000$ & 215,000 & 537,600 \\
\hline 11 DEXTER POWD & 69 & 151,710 & 6.85 & 20,882 & SP.CH. & & 20,882 & 354,437 & 121,400 & 303,400 \\
\hline \multirow[t]{2}{*}{12 CARSON } & 45.3 & 137,200 & 22.0 & 28,136 & $\infty$ & 29.5 & & 151,338 & & \\
\hline & & & 20.0 & 111,755 & SP.CH. & 70.5 & 139,891 & 302,676 & 109,800 & 274,400 \\
\hline 43 FALL RIVER & & $\$ 20,000$ & & & & & & & 96,000 & 240,000 \\
\hline 14 G0LDENDALE & 10 & 32,000 & & & TROUT & & & & 25,600 & 64,000 \\
\hline 45 IRRIGOK & 55 & 224,000 & 6.33 & 5,733 & S.ST. & & 5733 & 284,866 & 179,200 & 448,000 \\
\hline \multirow[t]{3}{*}{16 KLICKITAT } & $11.1-$ & 279,360 & 16.7 & 55,872 & $\mathrm{CO}$ & 31.7 & & & & \\
\hline & 17.8 & & 31.5 & 65,092 & SP.CH & 36.9 & & $32-52,000$ & 241,400 & 603,500 \\
\hline & & & 86.1 & 55,069 & F.CH. & 31.3 & 176,033 & $65-104$ & & \\
\hline \multirow[t]{2}{*}{47 LTL WH SAL } & 58.6 & 93,710 & 25.9 & 32,289 & SP.CH & 26.6 & & & & \\
\hline & & & 77.6 & 88,982 & F.CH & 73.4 & 121,271 & $153-726$ & 74,900 & 187,410 \\
\hline 18 OAK SPRINES & & 116,100 & 7.6 & 46,256 & S.ST. & & 46,256 & & 92,800 & 232,200 \\
\hline \multirow[t]{2}{*}{19 ROUNO BUTTE } & & 36,000 & 9.33 & 27,141 & SP.CH & 35.3 & 76,851 & & & \\
\hline & & & 12.43 & 49,710 & S.5T. & 64.7 & & & 28,800 & 72,000 \\
\hline 50 SPRING CREEK & 6.68 & & 68.16 & 194,510 & F.CH. & & 194,570 & 16176 & 136,000 & 340,200 \\
\hline 5I WARM SPRINGS & \multicolumn{2}{|c|}{$8.9-27.9133,860$} & 11.87 & 33,700 & SP.CH & & 33700 & 36,915 & 107,100 & 267,700 \\
\hline 52 ILLLARD & & 96,000 & 19.14 & 147,611 & CO & & 147,611 & & 76,800 & 192,000 \\
\hline 53 WIIARD FALLS & & 379,000 & & & & & & & 303,200 & 758,000 \\
\hline \multicolumn{11}{|c|}{54 CHELAA TROUT 9.98} \\
\hline 55 CHELAN FALLS & 5.13 & 38,240 & 6.76 & 83,154 & S.st. & & 83,154 & & 30,600 & 76,400 \\
\hline 56 ENTIAT NFH & & 83,688 & 19.50 & 51,159 & SP.CH. & & 51159 & & 66,900 & 167,400 \\
\hline \multirow[t]{2}{*}{57 LEAYENWCRTH } & 6.2 & 283,440 & 8.0 & 125,006 & 4.57 & 4.89 & 255,546 & & & \\
\hline & & & 16.98 & 130,546 & & & & 956196 & 226,700 & 566,800 \\
\hline 58 NELSON SPR & & 2,400 & 6.05 & 14,922 & S.ST & & 14922 & & 1,900 & 4,800 \\
\hline 59 NACHES & & 65,520 & 8.72 & 17,105 & S.ST. & & 17105 & & 54,200 & 131,000 \\
\hline 60 NILES SFE & 1.5 & 43,560 & & & 1 & & & & & \\
\hline 6) OHAK. & 6.2 & 13,824 & & & $T$ & & & & 11,000 & 27,600 \\
\hline
\end{tabular}




\begin{tabular}{|c|c|c|c|c|c|c|c|c|c|c|}
\hline \multirow{3}{*}{$\begin{array}{l}\text { HATCHER: } \\
\text { WAME }\end{array}$} & \multirow{3}{*}{$\begin{array}{l}\text { Flom } \\
\text { CFS }\end{array}$} & \multirow{3}{*}{$\begin{array}{l}\text { Matims } \\
\text { lofi }\end{array}$} & \multicolumn{8}{|c|}{ PRoDustlok } \\
\hline & & & \multicolumn{3}{|c|}{ AC UAL AVERAEE } & \multicolumn{5}{|c|}{ ESIIMATE } \\
\hline & & & rISH:B & LB/YEAF & SPECIES & PERCEN: & DENSIIY & FLOW & $.8 \mathrm{LB} / \mathrm{CF}$ & $2.018 / C R$ \\
\hline 62 PFIEST RAP I & 111.1 & $177_{7} 68$ & 83.14 & $10 \%, 979$ & $\mathrm{F.CH}$ & & 105979 & $25 \times 189$ & 142,100 & 355,400 \\
\hline 63 RINGD:. SAL & $25::-$ & $1,716,716$ & 12.89 & 161,850 & $\mathrm{SF}=\mathrm{CH}$. & 74.6 & 105,032 & $96.5-115,300$ & & \\
\hline & 30 & & 54.99 & 38,18 & F. CH & 25.4 & & & $1,437,400$ & $3,593,400$ \\
\hline 64 ROCKY REACH & & & & & & & & & & \\
\hline 65 TURTLE ROCK & 9 & 105,560 & & & & & & & 84,400 & 211,100 \\
\hline $\begin{array}{l}\text { 66 SPOKANE I } \\
67 \text { ASHBURN IS }\end{array}$ & 14.5 & 43,557 & & & 1 & & & & 34,800 & 87,100 \\
\hline 68 MELLS & $26.5 \%$ & & 6.27 & 97,617 & $5.5 ?$ & 68.7 & & $115.1 \cdot 141.6$ & & \\
\hline & 32.6 & & 550.2 & 922 & P.CH & 0.6 & & & & \\
\hline & & & 11.96 & 42,577 & S.CH & 30.7 & 142,116 & & & \\
\hline DQ WINTHRDF & & 74,200 & 71.1 & 56,511 & $S P . C H$ & & 56,511 & & 59,400 & 148,400 \\
\hline 70 YAKIMA & 4.1 & 72.570 & 750.7 & 533 & S.st. & & & & 75,600 & 189.100 \\
\hline 71 OWRESHAK. & 135 & 315,792 & 8.4 & 314,743 & S.ST. & & 314743 & $61446 ?$ & 252,000 & 631,600 \\
\hline 72 EAE.E & 1.97 & 52,720 & & & RESIDEN? & & & & 12,200 & 105,100 \\
\hline 73 HAGERMAN N. & $203-881$ & & & & & & & & & \\
\hline 74 HAGERMAN ST & .87 & 563,680 & 86.4 & 5156 & & 35.8 & & & 450,900 & $1,127,400$ \\
\hline & & & 22.4 & 9237 & $\begin{array}{l}\text { F.CH. } \\
\text { RESIDENT }\end{array}$ & 64.2 & & & & \\
\hline 75 HAYDEN CRK & 8 & 612,176 & & & & & & & 489,700 & $1,224,400$ \\
\hline 76 KDOSKIA & 35 & 36,158 & 18.98 & 22,134 & SP.CH. & 558 & & & & \\
\hline & & $13 i, 422 i$ & 7.83 & 17,506 & 5.51 & 44.2 & 39640 & 133,996 & 25,100 & 62,800 \\
\hline 77 LOOKING6LASS & 50 & 54,000 & & & & & & & 43,200 & 108,000 \\
\hline 78 LYONS FERPYY & 43 & 158,000 & & & $\begin{array}{l}\mathrm{FCH} \\
\text { SPCH }\end{array}$ & & & & 126,400 & 316,000 \\
\hline 79 LYONS TROUT 1 & 177.3 & 140,550 & 6.72 & 107,092 & S.ST & & 107,092 & & 112,400 & 281,100 \\
\hline BO MCCALL & 20 & 64,000 & & & RESIDENT & & & & 51,200 & 128,000 \\
\hline & & & 18.44 & 10,034 & S. CH & & 15,884 & & & \\
\hline 81 NIAGARA SP & 132 & 161,000 & 20.1 & 3,000 & $\begin{array}{l}\text { RESIDENT } \\
\text { S.ST. }\end{array}$ & & & & $\sqrt{28}, 800$ & 332,000 \\
\hline
\end{tabular}




\begin{tabular}{|c|c|c|c|c|c|c|c|c|c|c|}
\hline \multirow{3}{*}{$\begin{array}{l}\text { HATCHERY } \\
\text { MANE }\end{array}$} & \multirow{3}{*}{$\begin{array}{l}\text { FLON } \\
\text { ICFS: }\end{array}$} & \multirow{3}{*}{$\begin{array}{l}\text { VOLUAE } \\
\text { CCF }\end{array}$} & \multicolumn{8}{|c|}{ PRODUCTIDN } \\
\hline & & & \multicolumn{3}{|c|}{ ACTUH. AVERTIEE } & & & \multicolumn{2}{|c|}{ ESIIMATE } & \multirow[b]{2}{*}{$2.0 \mathrm{LB} / \mathrm{CF}$} \\
\hline & & & FISH/LB & LB/YEAR & SPECIES & PERCENT & DENSITY & FLON & $.8 \mathrm{LB} / \mathrm{CF}$ & \\
\hline 82 OXRON (ID) & 17.9 & 59,148 & & & & & & & 47,300 & 118,300 \\
\hline 83 PAHSIMEROI & 86 & 156,665 & & 622 & s. $\mathrm{CH}$ & 3.0 & & & & \\
\hline & & & & 19,900 & SP.CH & 97.0 & & & 125,000 & 313,000 \\
\hline 84 RAPID RUR & 52 & 320,000 & & & & & & & 256,000 & 640,000 \\
\hline 85 RED RIVER & 15 & 430,100 & 21.0 & 12,762 & SP.CH & & & & 344,100 & 860,200 \\
\hline 86 SAMTOOTH & 48 & 149,800 & & & SP.CH & & & & 119,800 & 299,600 \\
\hline 87 TUCANHON & $75-90$ & 307,786 & 50.2 & 6,497 & S.ST & & & & 246,200 & 615,600 \\
\hline BE VAILONA & & $110,25 ?$ & & & & & & & 88,200 & 220,600 \\
\hline 89 IMNAHA & & & & & & & & & & \\
\hline 90 RINGOLD-STH & $6-15$ & $1,672,704$ & 6.8 & 35,798 & S.ST & & 35,798 & 35,798 & 138,200 & $3,345,400$ \\
\hline
\end{tabular}


FULL PRODUCTION/FACILITY MODIFICATIONS/COSTS

HATCHEKY: ABEKNATHY NFH

LOCATION CODE: 1

1. ACTUAL PRODUCTION:

SPRCIES

F. CHINOOK

TOTAL $\begin{array}{ll}\text { A. POUNDS } & \text { B. PERCENT } \\ \mathbf{4 0 , 8 0 0} & 100\end{array}$

$40,801)$

2. THEOKETICAL PRODUCTION-- b a s ed on existing facilities :

- DENSITY POKMULA (.5 X L X VOL.)- 37,152 LB: 1b/CY- 2.15

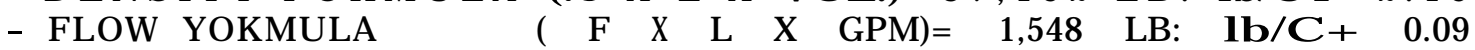

- AGENCY CRITERIA KANGE (.8 X VOL $)=13,800$ LB and $(2 \mathrm{X}$ VOL $)=34,600 \mathrm{LB}$

3. FACTORS CONTKOLLING PRODUCITON:

A. POND VOL.: * $17,281\left(\begin{array}{llllll}2 & 3 & 3 & 1 & 2\end{array}\right)$ c f i. facilities not fully utilized

B. WATEK: $240-300 \mathrm{CPM}$

i. enhance quality - a eration * $x^{*}$

- treatment 6 reclrc. *95X

$* \mathrm{x} *$

C. FISH BIOMASS:

i. decrease density $* X^{*}$

i i . rearing density

-lb/CY: 2.36

-lb/GPM: 170

MODIFICATION COMMENTS: Adult holding facilities are currently not used for rearing. Additional production could be realized by utilizing existing adult holding ponds, and recirculated water when rearing. None recommended.

* Currently used volumes

() Available Volumes

"X" Action item 
1. ACTUAL PKODUCTION:

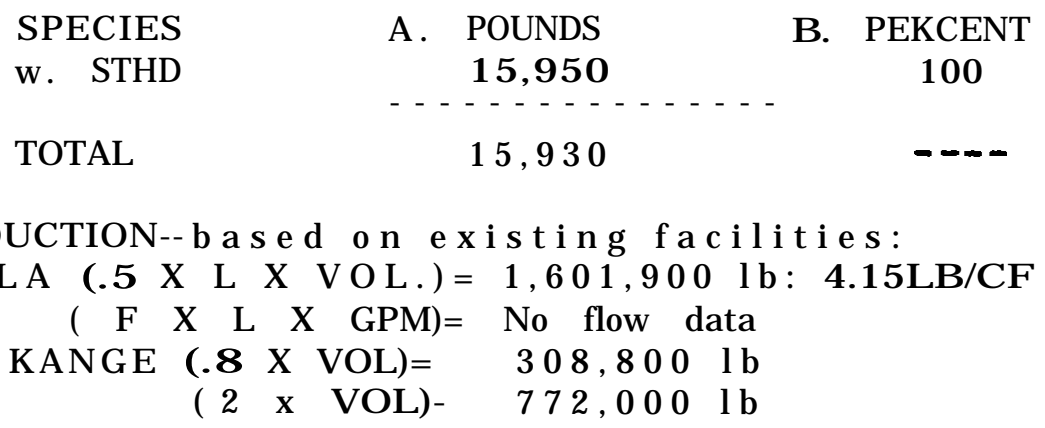

3. FACTORS CONTKOLLING PKODUCTION:

A. POND VOL.: $386,000 \mathrm{cf}$

I. facilities not fully utilized * $x^{*}$

B. WATER: NO DATA

I . increase amnt. available

i i. enhance quality

- a e ration ${ }^{*} x^{*}$
c. FISH BIOMASS:
i. increase density $* X *$
I I. increase feed * $x^{*}$
i i i. rearing density
$-1 \mathrm{~b} / \mathrm{CP} 0.04$

MODIFICATION COMMENTS: NONE KECOMMENDED. A e ration and an increase in food could allow a large increase in density/production. No flow data were available, however the creek which was darned to produce this pond is relatively small. There is a great disparity in the actual and the calculated production. This probably has to do with the fact that the facility has no support facilities for food storage and no housing for personnel. Feeding is probably speradic under these circumstances and therefore, density Is kept low to enhance the probability of survival.

* Currently used volumes

() Available Volumes

$* \mathrm{X}^{*}$ Action item 
1. ACTUAL PKODUCTION:

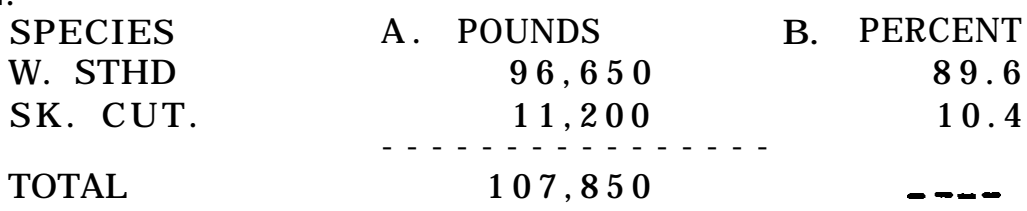

2. THEOKETICAL PRODUCTION-- bas ed on existing facilities:

- DENSITY FORMULA (.5 X L X VOL.) $=445,200 \mathrm{lb}: \mathrm{lb} / \mathrm{cf} 3.5$

- FLOW FORMULA ( F X L X CPM)=61,915 lb: lb/cf 0.5

- AGENCY CKITERIA RANGE (.8 X VOL) $=100,6001 \mathrm{~b}$ and

$(2 \mathrm{x}$ VOL) $251,4001 \mathrm{~b}$

3. FACTORS CONTKOLLING PKODUCTION:

A. POND VOL.: *(125,695) 135,275 cf total

b. WATEK: $5830 \mathrm{gpm}$

c. FISH HIOMASS:

I. increase density *X*

I i. current rearing density

$-1 \mathrm{~b} / \mathrm{CF} \quad 0.85$

-lb/tiPH 111.5

MODIFICATION COMMENTS: The potential for facility expansion is constrained by the rights to the available ground water and water in the creek. Only $20 \%$ of the available 40 acres of WDG land are presently in use. Additional water could be made available by using a recirculation system to provide an Increase in production. Use of adult holding ponds as rearing pond 6 during off season would increase space by $8 \%$.

4.ESTIMATED INCREASED PKODUCTION (TOTAL): 16,000 lb.

5. ESTIMATED CONSTKUCTION COSTS: $\$ 330,000$ w o u ld be us e d to develope additional water sources, build large rearing ponds, and upgrade holding Ponds to be used a 6 rearing ponds.

6. ESTIMATED INCREASES IN OPERATIONS COSTS: At a 1.5:1 c onversion rate, an additional $24,000 \mathrm{lb}$. of feed, $1 / 2 \mathrm{man}$ year.

*Currently used volume 6

() Available Volumes

*X* Action Item 
1. ACTUAL PRODUCTION:

SPECIES
F. CHIN OOK
COMO
W. STHD
SR. CUT.

TOTAL

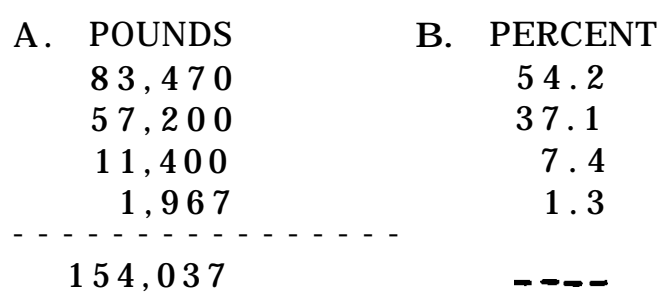

2. THEORETICAL PRODUCTION-- b a s ed on existing facilities:

- DENSITY FORMULA (.5 X L X VOL.) - 340,400 lb: 1b/cf 2.36

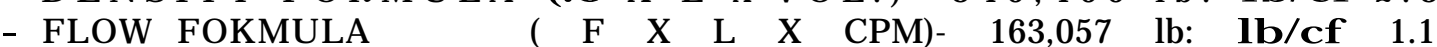

- AGENCY CRITERIA KANGE (.8 X VOL $)=115,2 O c) 1 b$

$$
\text { and ( } 2 x \text { VOL) } 288,0001 \text { b }
$$

3. FACTORS CONTKOLLING PKODUCTION:
A. POND VOL.: *(144,000) 156,750 cf t o t a l
B.WATEK: 51.25 CFS
c. FISH BIOMASS:
i. current rearing density
$-1 \mathrm{~b} / \mathrm{CF} \quad 1.07$
$-1 \mathrm{~b} / \mathrm{C} \mathrm{P} \mathrm{M} 6.7$

MODIFICATION COMMENTS: Potential facility expansion is constrained by the topography. Some additional water sources may be available, however, increased production would probably have to rely on a reuse system for any additional ponds. None recommended.

*Currently used volumes

() Available Volumes 
1. ACTUAL PRODUCTION:

$\begin{array}{lcc}\text { SPECIES } & \text { A. POUNDS } & \text { B. PEKCENT } \\ \text { F. CHINOOK } & 12,300 & 100\end{array}$

\section{TOTAL $12,300 *$}

* Note: 1982 brood reared at Spring Creek and released for imprinting in Big White Salmon Pond in 1983.

2. THEORETICAL PRODUCTION--based on existing facilities :

- AGENCY CRITERIA RANGE (.8 X VOL)' 11,100 LB and (2 X VOL)' 27,800 L B

3. FACTOKS CONTROLLING PKODUCTION:
A. POND VOL.: 13920 cf
B . WATEK: 3184 GPM

MODIFICATION COMMENTS: None recommended, according to the hatchery manager, there ha6 been a proposal to construct new pond 6 at a higher elevation 60 that pond 6 can be utilized at all river flows. 
1. ACTUAL PRODUCTION:

\begin{tabular}{lcc}
\multicolumn{1}{r}{ SPECIES } & A. POUNDS & B. PERCENT \\
F. CHINOOK & 238,194 & 65.4 \\
COHO & 126,022 & 34.6 \\
TOTAL & 364.216 & \\
\hline
\end{tabular}

2. THEORETICAL PRODUCTION--based on existing facilities:

- DENSITY FORMULA (.5 X L X VOL.)=685,700 lb: 1b/cf 2.29

- FLOW FORMULA ( F X L X CPM $)=140,800 \quad 1 \mathrm{~b}: \quad 1 \mathrm{lb} / \mathbf{c f} 0.85$

- AGENCY CRITERIA RANGE $(.8$ X VOL $)=239,500 \mathrm{lb}$ and

$(2 \times$ VOL) $598,8001 \mathrm{~b}$

3. FACTORS CONTROLLING PRODUCTION:

A. POND VOL.: $299,384 \mathrm{cf}$

I. new facilities * $x^{*}$

B. WATER: $20493 \mathrm{gpm}$

c. FISH BIOMASS:

i.enhance quality

IV. rearing density

- temperature

- a e ration

-treatment 6 recirc. $* x^{*}$

$-\mathrm{lb} / \mathrm{CF} \quad 1.22$

-lb/GPM 17.7

MODIFICATION COMMENTS: Land is available for the construction of new facilities. The hatchery manager stated that with adequate new well water and additional facilities the production at this facility could be doubled. We recommend an increase in the well water supply $(14,000 \mathrm{gpm})$ and rearing capacity $(300,000.0 \mathrm{cf})$.

4.ESTIMATED INCREASED PRODUCTION (TOTAL): 250,000 lb.

5. ESTIMATED CONSTRUCTION COSTS: $\$ 2,550,000$

6. ESTIMATED INCREASES IN OPERATIONS COSTS: Additional 375,000

lb feed, and 3 man years labor.

*X* Action Item 
ESTIMATED PRODUCTION INCREASE, CONSTRUCTION COSTS, AND OPERATIONAL COSTS BASED ON HATCHERY MANAGERS IMPROVEMENT IDEAS

HATCHERY: BONNEVILLE FISH HATCHERY PRODUCTION INCREASE: 250,000 LBS. NAME: FARR/PW

CONSTRUCTION COSTS:

A. FACILITIES

COSTS

1.INCUBATIORS

2.START TANKS

3.REARING

RACEWAYS

PONDS

$1 / \overline{2 \text { ACRE X } 5}$ FT

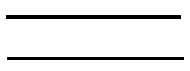

LOCATION CODE: 6

4.HOLDING

5.AERATORS
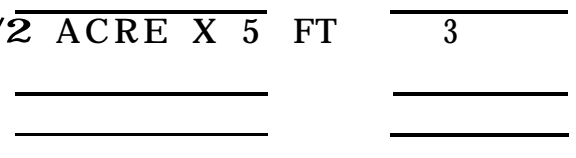

6.SITE WORK

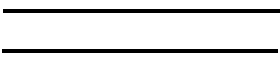

ATER SYSTEMS:

1.INTAKE

2.PUMPING AND $\overline{\text { WELLS } 4100}$ G $\overline{\text { PM } 4}$

$\$ 350,000$

3.HEATING/

CHILLING

4.OUTSIDE

PIPING

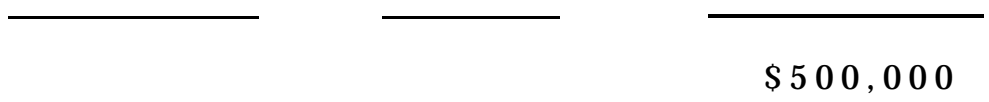

C. BUILDINGS

1.HATCHING

2.PUMP HOUSE

3.GARAGE

4. SHOP

5.REFRIDGERATION

6.STORAGE

7.RESIDENCE
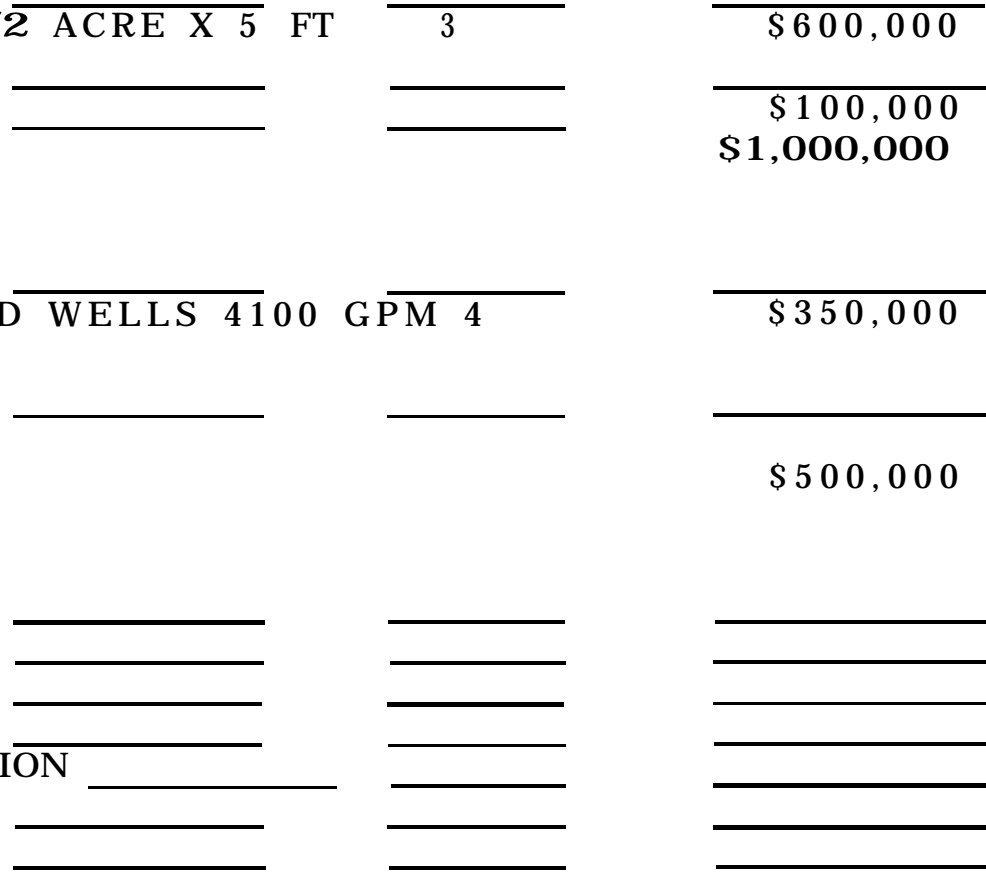

SUBTOTAL $\$ 2,550,000$ 
1. ACTUAL PHODUCTION:

\section{SPECIES \\ SP. CHINOOK}
A. POUNDS
143,100
t3. PERCENT
100
143,100

TOTAL

2. THEORETICAL PRODUCTION-- b a s ed o n e xisting facillities:

- DENSITY FOKMULA (.5 X L X VOL.)= 277,816 lb: $\mathbf{1 b / c f} 1.92$

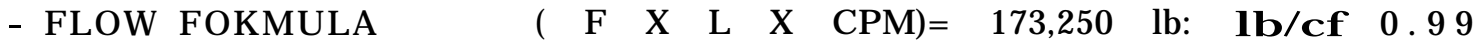

- AGENCY CRITERIA KANGE (.8 X VOL)- 115,456
and
$(2 \mathrm{X}$ VOL $)=288,640$

3. FACTOKS CONTROLLING PRODUCITON:
A. POND VOL.: $* 144,320\left(\begin{array}{llllll}1 & 6 & 7,0 & 0 & 0\end{array}\right)$ c f
B. WATER: $15,000 \mathrm{gpm}$
i. increase amnt. available "X"
c. FISH BIOMASS:
i current rearing density
$-1 \mathrm{~b} / \mathrm{CF} \quad 0.99$
-lb/GPM 9.54

MODIFICATION COMMENTS: Existing plan calls for increasing production by 1,OOO,OOO to 1,5000,000 smolts (dependent upon the species reared). Well water for tempering would enhance production. At recommended densities, additional volume $(212,500$ cf) and water $(18,000 \mathrm{gpm})$ would be required.

4.ESTIMATED INCREASED PRODUCTION ( $\mathrm{T}$ O T A L ) : $\mathbf{1 7 0 , 0 0 0 ~} \mathbf{1 b .}$

5. ESTIMATED CONSTRUCTION COSTS: $\$ 3,500,000$ ( t o in c l u d e additional hatching and pond rearing space, development of additional water sources, construction of support facilities).

6. ESTIMATED INCKEASES IN OPERATIONS COSTS: 255,000 lb feed and 3 man years labor.

*Currently used volumes

() Available Volumes 
1. ACTUAL PKODUCTION:

SPECIES
SP. CHINOOK
F. CHINOOK
COHO

TOTAL

\begin{tabular}{c} 
A. POUNDS \\
115,450 \\
153,288 \\
202,121 \\
\hline$-\ldots . .-\ldots$ \\
470,859
\end{tabular}

A. POUNDS

115,450

153,288

470,859

2. THEORETICAL PRODUCTION--bas ed on existing facilities:

- DENSITY FOKMULA (.5 X L X VOL.)= 1,694,558 lb: 1b/cf 2.29

- F L O W FORMULA $\left(\begin{array}{llllll} & \mathrm{F} & \mathrm{X} & \mathrm{L} & \mathrm{X} & \mathrm{CPM}\end{array}\right)^{\prime}$

- AGENCY CRITEKIA KANCE (.B X VOL)$513,357 \quad 1 \mathrm{~b}: \mathbf{1 b} / \mathbf{c f} 0.69$ and

3. FACTORS CONTROLLING PKODUCTION:
A. POND VOL.: $741,600(964,320)$ c f
B. WATER $74,888 \mathrm{gpm}$
C. FISH BIOMASS:
i rearing density
$-\mathbf{l b} / \mathbf{c f} \quad 0.63$
$-1 b / c f \quad 6.29$

MODIFICATION COMMENTS: REDUCE the flow, and the depth of the pond's coho and reared in to $4 \mathrm{ft}$. Land space and water are available for facility expansion. Currently there is no pollution abatement due to hydraulic constraints. We recommend the use of microbial treatment to reduce organic wastes and elevated BUD. Problems exist from small hydroprojects on Butter, Johnson, and Mill Creeks which negatively impact young salmon. Negative impacts are expected in terms of elevated temperatures if the Cowlitz Falls Hydro Facility is constructed.

* Currently used volumes (> Available Volumes 
HATCHERY: COWLITZ TKOUT LOCATION CODE: 10 NAME: PMW

1. ACTUAL PKODUCTION:

SPECIES

S. STHD

w. STHD

SK. CUT.

TOTAL
A. POUNDS

24,800

102,300

19,100

146,100
B. PEKCENT 16.9

69.9

13.1

2 .

PRODUCTION-- based on existing facilities:

- DENSITY FORMULA (.5 X L X VOL.)- 2,430,500 lb: 1b/cf 3.25

- F L O W FORMULA $(\mathrm{F} X \mathrm{~L} \quad \mathrm{X}$ GPM $)=$ $267,100 \quad 1 \mathrm{~b}: \mathbf{1 b} / \mathbf{c f} 0.36$

- AGENCY CRITEKIA KANGE (.8 X VOL)- 597,600 and

$\left(\begin{array}{lll}2 & \mathrm{x} & \mathrm{VOL}\end{array}\right)=1,494, \mathrm{OOO}$

3. FACTOKS CONTROLLING PKODUCTION:
A. POND VOL.: 747,000 c f
B. WATEK: $27354 \mathrm{gpm}$
C. FISH BIOMASS:

I. rearing density

$-1 b / c f 0.2$

-1b/gpm 5.34

MODIFICATION COMMENTS: 1. By using an endemic steelhead stock, production could be doubled without adding water or facilities. Endemic summer run stocks may not be available, but winter runs are. Also, spring chinook could be used In a polyculture mlxture.2. If additional water is available, considerably more fish could be reared If disease problems in water system can be solved. 3. Pollution abatement problems could he approached by use of microbial methods which would reduce organic materials and elevated HOD.

4. ESTIMATED INCREASED PKODUCTION (TOTAL): (1) 146,101) lb.

( 2 ) 60,000 $1 \mathrm{~b}$.

5. ESTIMATED CONSTRUTION COSTS: (1) Without new water or facilities, \$0. (2) With 20 cfs new water, $\$ 320,000$.

6. ESTIMATED INCREASES IN OPEKATIONS COSTS: No additional cost as large annual losses are experienced annually in WDG's attempt to produce non-endemic summer steelhead.

* Currently used volumes

() Available Volumes 
1. ACTUAL PRODUCTION:

SPECIES $\quad$ A. POUNDS $\quad$ B. PEKCENT

TOTAL: FACILITY NOT IN PRODUCTION

2. THEORETICAL PKODUCTION: b a s d on existing facilities:

* NOT A VIABLE FACILITY

FACTOKS CONTKOLLING PKODUCTION:

A.

B. WATER:

FISH BIOMASS:

MODIFICATION COMMENTS:

by Mt. St. Helens eruption in 1980 .

to reactivate the facility.

* Volume of currently used ponds 
1. ACTUAL PRODUCTION:

$\begin{array}{lcc}\quad \text { SPECIES } & \text { A. POUNDS } & \text { B. PERCENT } \\ \text { SP. CHINOOK } & 52,640 & 43.8 \\ \text { COHO } & 51,600 & 42.9 \\ \text { W. STHD } & 15,900 & 13.3 \\ \text { TOTAL } & 120,127 & \end{array}$

2. THEORETICAL PRODUCTION based on existing facilities:

- DENSITY FOKMULA (.5 x L x VOL.) 355,800 lb:2.97 lb/cf

- FLOW FORMULA ( F X L X CPM)- 216,098 lb:1.8 lb/cf

- AGENCY CRITERIA RANGE (.8 X VOL)- $96,00001 \mathrm{~b}$ : and ( $2 \mathrm{x}$ VOL $) 240,0001 \mathrm{~b}$ :

3. YACTOKS CONTROLLING PKODUCTION:
A. POND VOL.: *(120,000) c $\mathrm{f}$
B. WATEK: $25132 \mathrm{gpm}$
c. FISH BIOMASS:

I. rearing density

$-1 \mathbf{b} / \mathbf{c f} 1$. 0

-lb/gpm 4.8

MODIFICTION COMMENTS: Low creek flows and high temperatures limit production. It may be possible to Increase production with an enlarged recirculated water system complete with chillers and heaters. This would allow reduced summer growth and more natural growth rates in WINTER and spring.

4.ESTIHATED INCREASED PKODUCTION (TOTAL): 10,000 1 b.

5.. ESTIMATED CONSTRUCITON COSTS: $\$ 50,000$ for chillers and enlarged recirc. (no estimates for heating).

6. ESTIMATED INCREASES IN OPERATIONS COSTS: 15,000 lb feed.

* Volume of currently used ponds

( ) Volulme of total available pond space 
1. ACTUAL PRODUCTION:

SPECIES
E'. CHINOOK
COHO

TOTAL

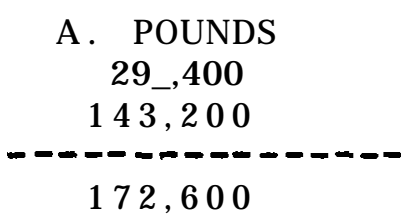

B. PEKCENT

17

83

2. THEORETICAL PRODUCTION-- bas ed on existing facilities:

- DENSITY FORMULA (.5 X L X VOL.)=557,600 lb:2.0 lb/cf

- FLOW FORMULA ( F X L X GPM)=120,100 lb:0.43 lb/cf

- AGENCY CRITERIA RANGE (.8 X VOL)'= $223,0001 \mathrm{~b}$ : and ( $2 \times$ VOL)- $557,6001 \mathrm{~b}$ :

3. FACTORS CONTROLLING PKODUCTION:

A. POND VOL.: $* 278,800$ c $\mathrm{f}$

B. WATEK: $200022.4 \mathrm{gpm}$

C. FISH BIOMASS:

i. rearing density

$-\mathrm{lb} / \mathrm{cf} .62$

$-1 \mathrm{~b} / \mathrm{g} \mathrm{p} \mathrm{m} 8.62$

MODIFICATION COMMENTS: March-April yearling mortalities indicate that densities are perhaps too high. The space and water for expansion exists. There are problems with the quality of the water seasonally In terms of silt loads, seasonal temperatures and pH. The manager indicated that fiscal constraints were a limiting factor in current production.

* Volume of currently used ponds

( ) Volume of total available pond space. 
1. ACTUAL PKODUCTION:

\section{SPECIES \\ $\mathrm{COHO}$ \\ s. STHD \\ w. STHD}

TOTAL
A. POUNDS
700
B PEKCENT
0.7
60,500
64.7
32,400
34.6

2. THEORETICAL PRODUCTION--b a sed o n existing facilities:

- DENSITY FOKMULA (.5 X L X VOL.)- 353,400 lb: lb/cf 3.74

- FLOW POHMULA ( F X L X CPM)- 50,556 1 b: lb/cf 0.53

$$
\text { and }(2 \times \text { VOL })=192,000
$$

3. FACTORS CONTROLLING PKODUCTION:
A. POND VOL.: $* \mathbf{9 6 , 0 0 0}$ c $\mathrm{f}$
B. WATER: $3000 \mathrm{gpm}$
C. FISH BIOMASS:
i. rearing density
$-\mathrm{lb} / \mathrm{cf} 0.98$
$-\mathrm{lb} / \mathrm{gpm} 31.2$

MODIFICATION COMMENTS: None recommended. Summer water availability is limiting for this facility.

* Currently used volumes

() Available Volumes 
1. ACTUAL PRODUCTION;

SPECIES

$\mathrm{COHO}$

S. STHD
A. POUNDS

17,700

25,400
B. PEKCENT

100

100

(two different years) TOTAL Average $-21,550$

e m - -

2. THEORETICAL PRODUCTION-- based on existing facilities:

- DENSITY FOKMULA (.5 X L X VOL.) = $100,8001 \mathrm{~b}: \mathbf{1 b} / \mathbf{c f} 3.5$

$\begin{array}{llllllllll}\text { - FLOW FORMULA } \quad\left(\begin{array}{llllll} & \mathrm{F} & \mathrm{X} & \mathrm{L} & \mathrm{X} & \mathrm{GPM}\end{array}\right)= & 31,100 & \mathrm{lb}: & \mathbf{1 b} / \mathbf{c f} & 1.08\end{array}$

- AGENCY CKITEKIA KANGE (.s X VOL)= 23,000 and

$(2 \mathrm{X}$ VOL $)=57,600$

3. PACTOKS CONTROLLING PRODUCITONL
A. POND VOL.: $* 28,800$ c $\mathrm{f}$
B. WATER: $2959.6 \mathrm{gpm}$
C. FISH BIOMASS:
i. rearing density
$-1 \mathbf{b} / \mathbf{c f} \quad 0.75$
$-1 \mathrm{~b} / \mathrm{g} \mathrm{p} \mathrm{m} 7.28$

MODIFICATION COMMENTS: None recommended.

* Currently used volumes

(> Available Volumes 
1. ACTUAL PKOUUCTION:

SPECIES

S. STHD

W. STHD

TOTAL
A. POUNDS

13,000

12,100

25,100
B. PEKCENT

51.2

48.3

2. THEORETICAL PRODUCTION-- b a s ed o n e $\mathrm{xisting}$ facilitie s:

- D E N S I T Y FORMULA (.5 X L X V O L. ) =

- FLOW FOKMULA $\left(\begin{array}{lllll}\mathrm{F} & \mathrm{X} & \mathrm{L} & \mathrm{X} & \mathrm{CPM}\end{array}\right)=$

- AGENCY CKITEKIA RANGE (.8 X VOL)-
$2,125,400 \mathrm{l} \mathrm{b}: 1 \mathrm{~b} / \mathrm{cf} 4.1$

$27,000 \quad 1 \quad b: 1 b / c f .05$ 414,700

3. FACTORS CONTKOLLINC PKODUCTION:

A. POND VOL.: *51ti,400 c f

B. WATEK: $2197.3 \mathrm{gpm}$

C. FISH BIOMASS:

i. rearing density

$-1 \mathbf{b} / \mathbf{c f} \quad 0.05$

-lb/gpm 11.42

MODIFICATION COMMENTS: Unless the amount of water can be increased (which does not appear possible) it does not appear that additional enhancement is practical. None recommended.

* Currently used volumes

() Available Volumes 
1. ACTUAL PRODUCTION:

F. CGECIES
COHO

TOTAL

\begin{tabular}{l} 
A. POUNDS \\
21,800 \\
21,200 \\
\hline 43,000
\end{tabular}

b. PEKCENT 50.7 49.3

- a - -

2. THEUKETICAL PRODUCTION-- b a s ed on existing facilities:

- DENS I T Y FORMULA (.5 X L X VOL.) = 257,101): 2.14 1b/cf

- FLOW FOKMULA ( Y x L x CMP $)=28,900: 0.24$ 1D/Cf

- A G E N C Y CRITERIA RANGE ( .8 X VOL $>=95,900$

$$
\left.\begin{array}{llll}
\text { and } & (2 x & \mathrm{x} & \mathrm{VOL}
\end{array}\right)=239,90 \mathrm{ou}
$$

3. FACTOKS CONTROLLING PKODUCTIUN:
A. POND VOL.: " 119,950 c f
B. WATER: $4484.3 \mathrm{~g} \mathrm{pm}$
C. FISH BIOMASS:
i. rearing density
$-\mathbf{1 b} / \mathbf{c f} \quad 0.36$
$-1 \mathrm{~b} / \mathrm{gpm} 9.59$

MODIFICATION COMMENTS: None recommended. Land not available, sources of available quality water in question.

* Currently used volumes

() Available Volumes 
1. ACTUAL YKODUCTION:

$\begin{array}{lcc}\text { SPECIES } & \text { A. POUNDS } & \text { B. PERCENT } \\ \text { F. CHINOOK } & 44,900 & 100 \\ \text { TOTAL } & 44,900 & \end{array}$

2. THEOKETICAL PRODUCTION--based on existing facilities:

- DENSITY FORMULA (.5 X L X VOL.)= 1,603, OOO $1 \mathrm{~b}: 1 \mathrm{~b} / \mathbf{c f} 1.6$

- AGENCY CKITEKIA RANGE (.8 X VOL)' $=801,5001 \mathrm{~b}$ : and $(2 \mathrm{x}$ VOL $)=2,003, \mathrm{OOO} 1 \mathrm{~b}:$

3. FACTORS CONTROLLING PRODUCITON:

A. POND VOL.: 1,001),880 c $\mathrm{f}$

B. WATEK: No Data

c. FISH BIOMASS:

1. rearing density

$-1 \mathrm{~b} / \mathrm{cf} .045$

$-1 \mathrm{~b} / \mathrm{gpm}$

MODIFICATION COMMENTS: Increased production may be achieved by improving the water quality through aeration (no water data was available) and feeding.

4.ESTIMATED INCKEASED PKODUCTION (TOTAL): 50,000

6. ESTIMATED INCKEASES IN OPERATIONS COSTS: 75,000 lb of feed

* Volume of currently used ponds

( $>$ Volume of total available pond space 
1. ACTUAL PRODUCTION:

$\begin{array}{lcc}\quad \text { SPECIES } & \text { A. POUNDS } & \text { B. PEKCENT } \\ \text { SP. CHINOOK } & 20,400 & 27.8 \\ \text { F. CHINOOK } & 52,100 & 70.9 \\ \text { COHO } & 1,000 & \\ \text { TOTAL } & 73,500 & \end{array}$

2. THEORETICAL PRODUCTION-- bas ed on existing facilities:

- D E N S I T Y FORMULA (.5 X L X V O L .) = $330,1001 \mathrm{~b}: \mathbf{1 b} / \mathbf{c f} 2.45$

- FLOW FOKMULA ( $\mathrm{F} \times \mathrm{x}$ L X GPM)- 44,100 $1 \mathrm{~b}: \quad$ Ib/cf 7.36

- AGENCY CRITERIA KANGE (.8 X VOL) $=107,700 \mathrm{lb}$ and

$(2 \mathrm{x}$ VOL) $269,300 \mathrm{lb}$

3. FACTORS CONTKOLLINC PRODUCITON

A. POND VOL.: * * $134,640(145,280) \mathrm{cf}$

B. WATER: $5995.5 \mathrm{gpm}$

c. FISH BIOMASS:

i. rearing density

$-1 \mathrm{~b} / \mathbf{c f} \quad 0.55$

$-1 \mathrm{~b} / \mathrm{g} \mathrm{p} \mathrm{m} 12.26$

MODIFICATION COMMENTS: A lteration of existing facilities to include an Increase in water by $20 \mathrm{cfs}$ and an increase in rearing pond space. According to the hatchery manager, an increase in the water supply from the Kalama Kiver would allow maximum utilization of the existing facilities. This increase production by 50,000 pounds. Additional requirements are a modernization of the existing facilities, and moving the existing shop and garage to provide room for the construction of a large adult holding pond. This would allow the existing holding ponds to be used for fish rearing. The new pond could be used for holding and rearing an additional 50,000 pounds of fall chinook.

4.ESTIMATRED INCREASED PRODUCTION (TOTAL): $1000,000001 \mathrm{~b} \mathrm{~s}$.

\section{ESTIMATED CONSTRUCTION COSTS: $\$ 955,000$}

6. ESTIMATED INCKEASES IN OPERATIONS COSTS: $150,00 \mathrm{lb}$ feed, $1-1.5 \mathrm{man}$ years of labor.

* Volume of currently used ponds

( ) Volume of total available pond space 
ESTIMATED PKODUCTION INCREASE, CONSTKUCTION COSTS, AND OPEKATIONAL COSTS BASED ON HATCHEKY MANAGEKS IMPROVEMENT IDEAS

HATCHERY: KALAMA FALLS CONSTRUCTION COSTS:

A. FACILITIES

COSTS

1.INCUBATOKS 2.STAKT TANKS

3.REARIGN

KACEWAYS

PONDS

$\overline{1 / 2 \mathrm{ACK} F X S^{\prime}}$

LOCATION CODE: 18

(KEMODEL EXISTING ADULT

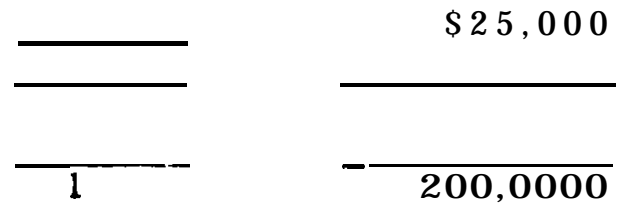

HOLDING PONDS FOK REARING)

6

250,000

4 .HOLDINC

5.aERATORS

6.bIOFILTERS
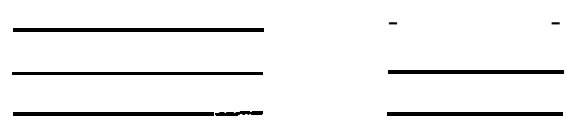

B. WATEK SYSTEMS:

1.INTAKE

2.PUMPING
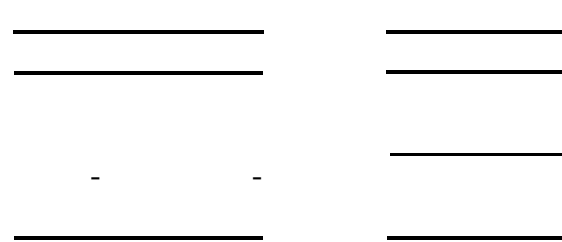

S180,OOU

3,HEATING/

CHILLING

4.0UTSIDE PIPING

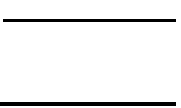
$\$ 60, \mathrm{OOU}$

c . BUILDINGS

1.HATCHING

2.PUMP HOUSE

3.GARAGE

4.SHOP

$30^{\prime} \times 60$ '

5,DEMOLITION

$20^{\prime} \times 30$ '

6. STORAGE

7.rESIDENCE

OF EXISTING STKUCTUKES
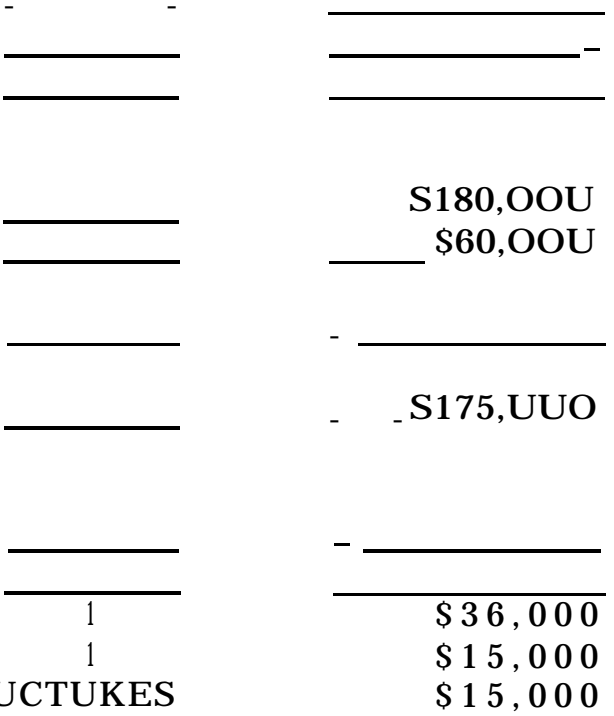

SUBTOTAL $\$ 955,000$ 
1. ACTUAL PRODUCTION:

$\quad$ SPECIES
SP. CHINOOK
F. CHIN OOK
COHO
W. STHD

TOTAL

A. POUNDS
1,5000
45,800
117.800
11,300
176,400

B. PERCENT

0.8

26.0

$6 \mathrm{~b} .8$

6.4

2. THEOKETICAL PRODUCTION--0 bas ed on existing facilities:

- DENSITY FORMULA (.5 X L X VOL.) = $616,9001 \mathrm{~b}: 1 \mathrm{~b} / \mathrm{cf} 2.6$

- FLOU FORMULA ( F X L X CPM)- $9,1301 \mathrm{~b}: \quad \mathbf{l b} / \mathbf{c f} 0.04$

- ACENCY CKITERIA RANGE $(.8 \times$ VOL $)=189,1001 \mathrm{~b}$ and

$(2 \mathrm{x}$ VOL $)=472,701) 1 \mathrm{~b}$

3. FACTORS CONTRLLING PRODUCTION:
A. POND VOL.:
" $236,370 \mathrm{cf}$
B WATEK: 11.97.3 g p m
c. FISH BIOMASS:
iv rearing density
-1b.cf 0.75
-lb/gpm 147.3

MODIFICATION COMMENTS: Additional water is apparently not available because of the reuse. It may be possible to increase production by rearing more fall chinook and chum salmon.

* Currently used volumes

O Available Volumes 
1. ACTUAL PRODUCTION:

$\begin{array}{lcc}\text { SPECIES } & \text { A. POUNDS } & \text { B. } \\ \text { S. STHD } & 26,400 & 100 \\ \text { SK. CUT. } & 35,000 & 100 \\ \text { TOTAL } & 31,150 & \end{array}$

2. THEORETICAL PRODUCTION-- bas ed on existing facilities:

- DENSITY FOKMULA (.5 X L X VOL.)= 1,021,975 lb: 1b/cf 3.9

- FLOW 'FORMULA ( F X L X GYM $)=6,1001 \mathrm{~b}: \quad 1 \mathbf{b} / \mathbf{c f} 0.02$

- AGENCY CKITEKIA KANGE (.8 X VOL)- 2051,600 $1 \mathrm{~b}$ and $\quad(2 \times$ VOL $)=524,0001 \mathrm{~b}$

3 . FACTORS CONTROLLING PRODUCTION:

A. POND VOL.: 262,045 c f

B. WATEK: 25,442-31,881 gpm

C. FISH BIOMASS:

i. rearing density

$-1 \mathrm{~b} / \mathrm{cf}$ u. 12

$-1 \mathrm{~b} / \mathrm{g} \mathrm{p} \mathrm{m} \mathrm{1.22-U.YU}$

MODIFICATION COMMENTS: The ponds are apparently not being fully utilized from the standpoint of both biomass per volume and biomass per flow. The densities could be increased ( 132,000 lb). The original plans included the construction of 12 additional raceways. There exists sufficient land and water for expansion. 4.ESTIMATED INCREASED PRODUCTION ( T O T A L ) : 163,000 $1 \mathrm{~b}$.

5. ESTIMATED CONSTRUCTION COSTS: \$865,000

6. ESTIMATED INCREASES IN OPERATIONS COSTS: 244,500 lb feed and 2 man years of labor.

* Volume of currently used ponds

( ) Volume of total available pond space 
ESTIMATED PKODUCTION INCREASE, CONSTRUCTION COSTS, AND OPERATIONAL COSTS BASED ON HATCHEKY MANAGEKS IMPROVEMNET IDEAS HATCHEKY: LEABURG PKODUCTION INCREASE: 70,000 LBS. NAME: FAKK/PW

CONSTRUCTION COSTS:

A. FACILITIES SIZE NUMBER COSTS

1.INCUBATORS

2.START TANKS

3.REAKING

KACEWAYS 20X98.5X3'

PONDS

4,HOLDING

5.AEKATOKS

6.BIOFILTERSA

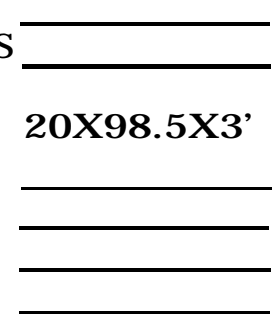

B. WATER SYSTEMS:

1.INTAKE

2.PUMPING

3.HEATING/

CHILLING

4.OUTSIDE

PIPING
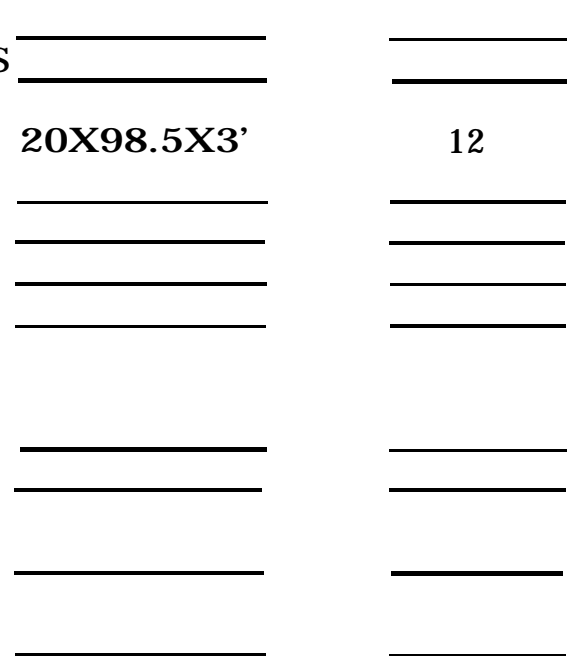

$\$ 17,500$

LOCATION CODE 20

PINGS

1.HATCHING

1.HATCHING
2.PUMP HOUSE

3.GARAGE

4.SHOP

5. K EFKI DGER.AT $\overline{\mathrm{ION}}$

6.S TOKA.GE

7. KESID ENCG
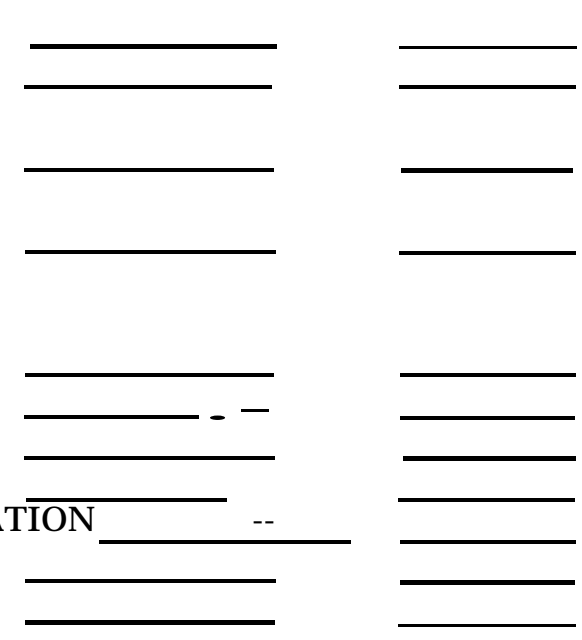

$\$ 67,500$

$\$ 600,000$
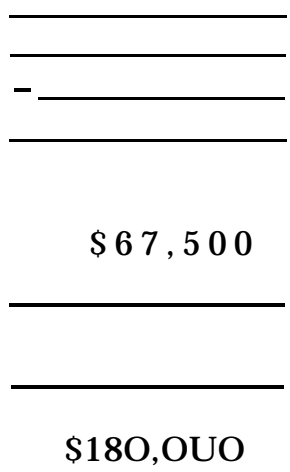

C. BUILDINGS

SUBTOTAL $\$ 865,000$ 
1. ACTUAL PKODUCTION:

\author{
SPECIES \\ SP. CHINOOK \\ F. CHINOOK \\ $\mathrm{COHO}$
}

TOTAL

\author{
A. POUNDS \\ 80,100 \\ 2,400 \\ 245,000 \\ 327,500
}

2. THEORETICAL PRODUCTION-- bas ed o n existing facilities:

- DENSITY FOKMULA (.5 X L X VOL.) $=941,8001 \mathrm{~b}: 1 \mathrm{~b} / \mathbf{c f} 2.9$

- F L O W FORMUAL ( F X L X CPM $)=564,7001 \mathrm{~b}: \quad 1 \mathrm{~b} / \mathbf{c f} 1.7$

- AGENCY CKITEKIA RANG (.tl X VOL) $=260,0001 \mathrm{~b}$ and

$(2 \mathrm{X}$ VOL $)=650,600 \mathrm{lb}$

3. FACTORS CONTROLLING PRODUCTION:

A. POND VOL.: 325,320 cf $(4136,820)$

B. WATER: $65022 \mathrm{gpm}$

C. FISH BIOMASS:

i. rearing density

$-1 \mathbf{b} / \mathbf{c f} 1$. 0

$-1 \mathrm{~b} / \mathrm{gpm} 5.0$

MODIFICATION COMMENTS: Production at this facility could be achieved by construction of three off station rearing ponds.

Land is available about one mile downstream on Johnson Creek for a 70-80,000 cubic foot rearing pond. Water would be supplied by gravity from the creek.

Land is available above the existing Davis Creek Pond for an additional 70,000 cubic foot rearing pond. A smalldam is recommended to impound water on Davis Creek upstream of the recommended pond site. This would allow both the existing pond and the recommended facility to be supplied water by gravity from the recommended impoundment.

Land adjacent to Colvin Creek could be used to construct a 70,000 cubic foot rearing pond. Water could be supplied from a source developed on Colvin Creek or from the existing Lewis Kiver Hatchery water supply system.

4.ESTFMATED INCREASED PRODUCTION (TOTAL): 168,000 1 b.

5. ESTIMATED CONSTRUCTION COSTS: $\$ \mathbf{1 , 1 5 2 , 5 0 0}$

6. ESTIMATED INCKEASES IN iperations COSTS: 252,500 $1 \mathrm{~b}$. f e e d,

3 man years of labor.

* Volume of currently used ponds

( ) Volume of total available pond space 
ESTIMATED PKODUCTION INCKEASE, CONSTRUCTIONCOSTS, AND OPERATIONAL COSTS BASED ON HATCHEKY MANAGEKS IMPKOVENENT IDEAS

HATCHEKY: $\quad$ LEWIS KIVEK

PKODUCTION INCKEASE: 63,000 LBS.

CONSTKUCTION COSTS:

A. FACILITIES

1.INCUBATORS

2.STAKT TANKS

3.REARING

RACEWAYS

$\mathrm{P} \quad \mathrm{O} \quad \mathrm{N} \quad \mathrm{D} 2 \% \mathrm{X70X5( \textrm {FT } )}$

4.HOLDING

5,AEKATOKS

6.BIOFILTERS

B WATER SYSTEMS:
1.INTAKE
2.PUMPING
3.HEATING/
CHILLING
4OUTSIDE
PIPING
5.SMALL
DAM

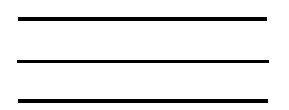

SIZE

NUMBER

COSTS

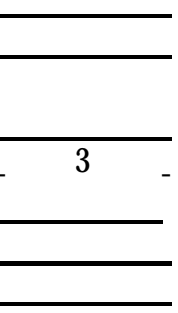

LOCATION CODE 23

NAME: FARK/I'W
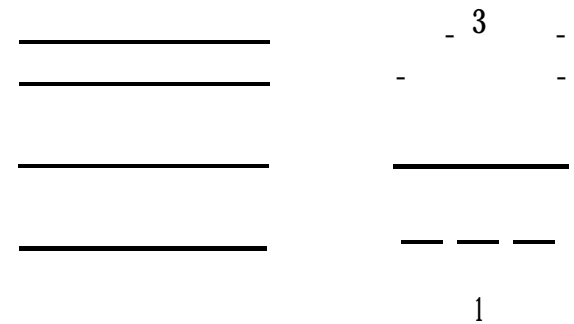

$-. \$ 120,000$

$\$ 270,0011$

$\$ 45,000$

c . BUILDINGS

1.HATCHING

2.PUMP HOUSE

3.GAKACE

4.SHOP

5.REFRIDGERAT $\overline{\mathrm{ION}}$

6.STORAGE

7.RESIDENCE
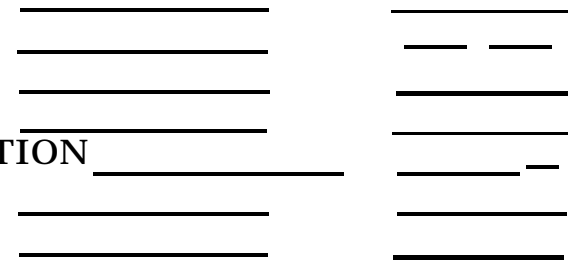

SUBTOTAL $\$ 1,152,500$ 
1. ACTUAL PKODUCTION:

\begin{tabular}{lrc}
\multicolumn{1}{c}{ SPECIES } & A. POUNDS & B. \\
SP CHINOOK & 16,300 & -- \\
F. CHINOOK & 27,700 & 26.1 \\
COHO & 78,500 & 73.9 \\
TOTAL & 106,200 &
\end{tabular}

2. THEUKETICAL PRODUCTION-- b a s ed on existing facilities:

- D E N S I T Y FORMULA (.5 X L X VOL.) = 208,180 lb: 1b/cf 2.25

$\begin{array}{lllllllllll}\text { - F L O W FORMULA } \quad\left(\begin{array}{lllll} & \mathrm{F} & \mathrm{L} & \mathrm{X} & \mathrm{CPM}\end{array}\right)= & 56,000 & \mathrm{lb}: & \mathbf{1 b} / \mathbf{c f} & 0.6\end{array}$

- AGENCY CRITERIA KANCE (.tl X VOL)- 73,901) l b and

$\left(\begin{array}{lllll}2 & \mathrm{x} & \text { VOL }\end{array}\right) \mathrm{ld} 4, \mathrm{t} 100 \mathrm{l} \quad \mathrm{b}$

3. FACTORS CONTROLLING PKODUCTION:

A. POND VOL.: "92,440 c f

B. WATEK: $8296 \mathrm{~g} \mathrm{p} \mathrm{m}$

c. FISH BIOMASS:

Iv. rearing density

$-\mathbf{1 b} / \mathbf{c f} \quad 1.15$

$-1 \mathrm{~b} / \mathrm{gpm} \quad 12.8$

MODIFICATION COMMENTS: We recommemd a decrease in the rearing density to increase net production. Production can also be increased at this facility by the construction of two 1/4 acre rearing ponds and an increase in the available water supply (see hatchery summary for details).

4.ESTIMATED INCREASED PRODUCTION (TOTAL): 70,0000 $1 \mathrm{~b}$

5. ESTIMATED CONSTRUCITON COSTS: \$542,500

6. ESTIMATED INCREASES IN OPERATIONS COSTS: $105,000 \mathrm{lb}$ feed, and one additional man year labor.

* Volume of currently used ponds

( ) Volume of total available pond space 
ESTIMATED PKODUCTION INCKEASE, CONSTKUCTION COSTS, AND OPERATIONAL COSTS BASED ON HATCHEKY MANAGEKS IMPROVEMENT IDEAS

HATCHEKY: LOWER KALAMA

LOCATION CODE: 22

PKODUCTION INCKEASE: 70,000 LBS. NAME FARR/PW

CONSTKUCTION COSTS:

A. FACILITIES

SIZE

1.INCUBATRS

2.START TANKS

3.REARING KACEWAYS PONDS

4,HOLDING

5.AEKATOKS

6.BIOFILTERS

B. WATEK SYSTEMS:

1.INTAKE

2,PUMPING

3.HEATING/

CHILLING

4,OUTSIDE

PIPING

c . BUILDINGS

1.HATCHING

2. PUMP HOU SE

3. GAKA GE

4. $\mathrm{s} \mathrm{HOP}$

5. KEFR IDGE KATION

6. STOR AGE

7RESUDEBCE
NUMBER
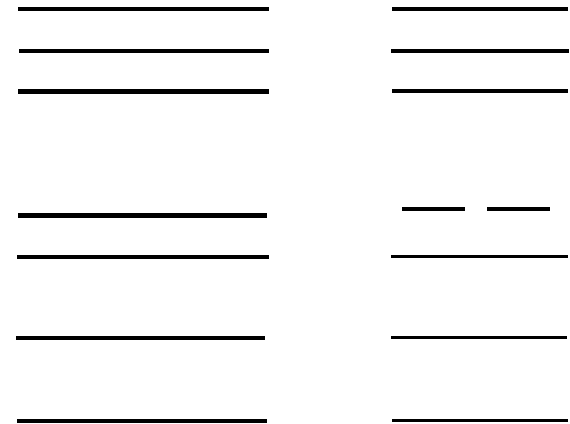
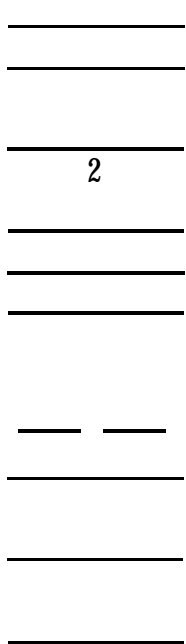

$\$ 80,000$

$\$ 17,500$

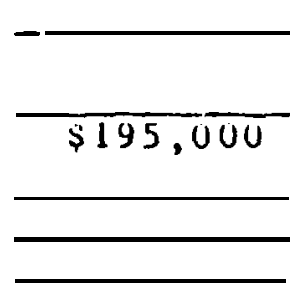

$\$ 14 \mathrm{c}), 000$

$\$ 75,000$
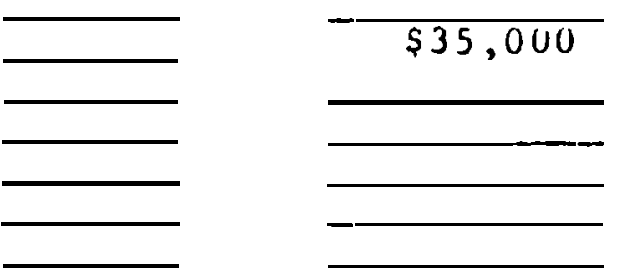

SUBTOTAL $\$ 542,500$ 
1. ACTUAL PKODUCTION:

SPECIES
SP. CH INOOK
S. STHD
W. STHD

TOTAL

\begin{tabular}{cc} 
A. POUNDS & B. PERCENT \\
34,500 & 58.2 \\
3,200 & 5.4 \\
21,600 & 36.4 \\
\hline 59,300 & \\
\hline
\end{tabular}

2. THEOKETICAL PKODUCTION--based on existing facilities:

- DENSITY FOKMULA (.5 X L X VOL.) $=222,5001 \mathrm{~b}: 2.6 \mathrm{lb} / \mathrm{cf}$

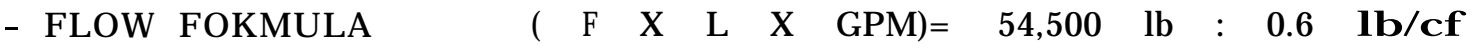

- AGENCY CRITEKIA KANGE (.8 X VOL)= $68,7001 \mathrm{~b}$ and

3. FACTORS CONTROLLIGN PKODUCTION

A. POND VOL.: 85,904 cf

B. WATEK: $7680 \mathrm{~g} \mathrm{p} \mathrm{m}$

c. FISH BIOMASS:

i. rearing density

$-1 \mathrm{~b} / \mathrm{cf} \quad 0.69$

$-1 \mathrm{~b} / \mathrm{gpm} 7.7$

MODIFICATION COMMENTS: Construct additional rearing capacity. Increase the available water supply, and increase the incubation water heating capacity. Land and water are available for 5-6400 cubic foot raceways.

4.ESTIMATED INCKEASED PKODUCTION (TOTAL): 25,600 $1 \mathrm{~b}$.

5. ESTIMATED CONSTRUCTION COSTS: $\$ 425,000$

6. ESTIMATED INCREASES IN OPERATIONS COSTS: Increased O\&M costs will include the cost of $3841301 \mathrm{~b}$ of feed and $1 / 2 \mathrm{man}$ year of $l$ a bor.

* Volume of currently used ponds

( ) Volume of total available pond space 
ESTIMATED PRODUCTION INCREASE, CONSTRUCTION COST AND

OPEKATIONAL COSTS BASED ON HATCHEKY MANAGERS IMPKOVEMENT

IDEAS

HATCHEKY: MARION FOKKS LOCATION CODE: 23

PKODUCTION INCKEASE: 26,400 LBS. NAME: FAKR/PW

CONSTKUCTION COSTS:

A. FACILITIES

SIZE NUMBEK

Costs

1.INCUBATORS

2.STAKT TANKS

3.REARING

KACEWAYS 2OX8UX3'

PONDS

4.HOLDING

5.AEKATOKS

6.BIOFILTERS

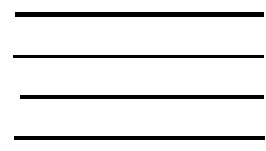

B. WATEK SYSTEMS:

1.INTAKE

2. PUMYING

3.HEATING/

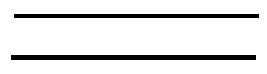

CHILLING (HEATING)

4.0UTSIDE

PIPING
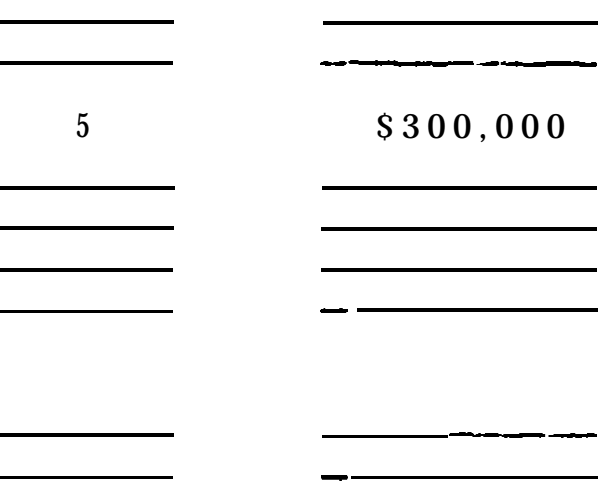

_- $\$ 50,000$

75,000

c . BUILDINGS

1.HATCHING

2 .PUMP HOUSE

3.GAKAGE

4.SHOP

5.REFRIDGERATIN

6.STORAGE

7.KESIDENCE
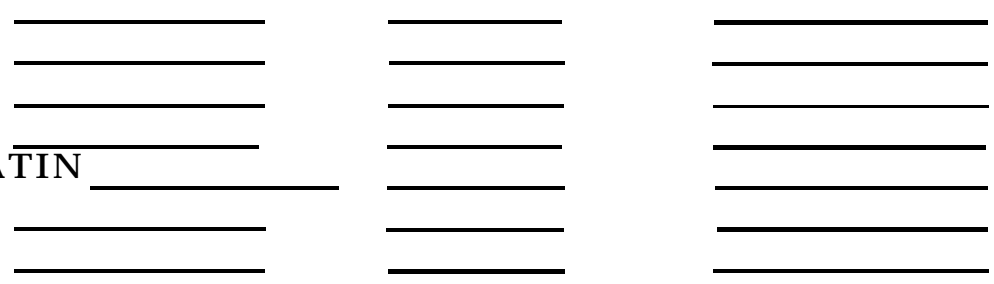

SUBTOTAL $\$ 425,000$ 
1. ACTUAL PKODUCTION:

\author{
SPECIES \\ SP. CHINOOK \\ s . STHD
}

TOTAL
A. POUNDS
$126,2 \mathrm{OO}$
$15,7 \mathrm{OO}$
141,950

B. PERCNET

86.9

11.1

2. THEOKETICAL PRODUCTION-- bas ed on existing facilities:

- DENSITY YOKMULA (.5 X L X VOL.)=

- FLOW FOKMULA

- AtiENCY' CRITERIA KANCE and

$$
\begin{aligned}
& (.8 \times \text { VOL })=110,880 \mathrm{l} \mathrm{b} \\
& (2 \times \text { VOL }>=277,200 \quad 1 b
\end{aligned}
$$

3. FACTOKS CONTKOLLING PRODUCTION:
A. POND VOL.: 138,600 cf
B. WATER: 14,100 g p m
c. FISH BIOMASS:
$-1 \mathrm{~b} / \mathrm{cf} \quad 1 . \mathrm{O} 2$
$-\mathrm{lb} / \mathrm{g} \mathrm{p} \mathrm{m} 10.1$
i. rearing density

MODIFICATION COMMENTS: Se e modification comment based on hatchery managers ideas in the Hatchery Summary.

\section{ESTIMATED INCREASED PRODUCITON (TOTAL): 14O,OOO $1 \mathrm{~b}$.}

\section{ESTIMATED CONSTRUCTION COSTS: $\$ 1,905,000$}

6. ESTIMATED INCREASES IN OPERATIONS COSTS: Funds for 210,000 $1 \mathrm{~b}$. of feed and $1.5 \mathrm{man}$ years of labor.

* Currently used volumes

() Available Volumes 
ESTIMATED PKODUCTION INCREASE, CONSTKUCTION COSTS, AND

OPEKATIONAL COSTS BASED ON HATCHEKY MANAGEKS IMPKOVEMENT IDEAS

HATCHERY: MCKENZIE

LOCATION CODE: 24

PKODUCTION INCKEASE: 140,000 LBS. NAME: FARR/PW

CONSTKUCTION COSTS:

A. FACILITIES

1.INCUBATOKS

2.STAKT TANKS

3.REARIGN

KACEWAYS

PONDS

4.HOLDINC

5.AEdATOKS

6.BIOFILTERS

SIZE

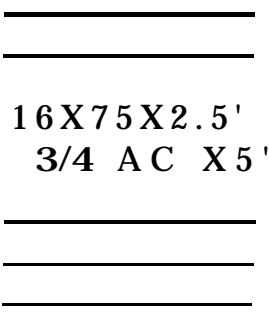

B. WATEK SYSTEMS:

1.INTAKE

2. PUMPING

3.HEATINC/

CHILLING

4.0UTSIDE

PIPING

c . BUILDINGS

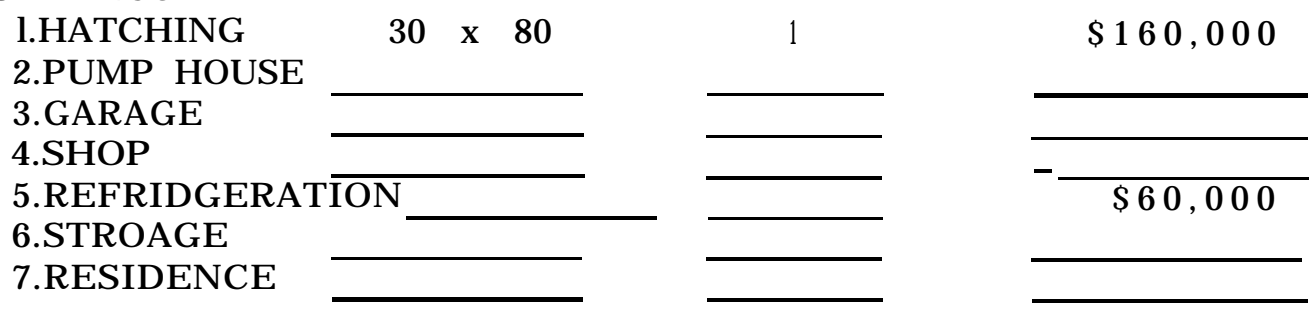

COSTS

$\$ 35,000$

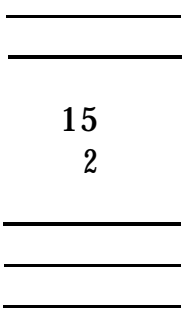

$\$ 675,000$

$\$ 425,000$

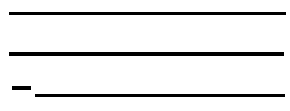

Sli35,OOO
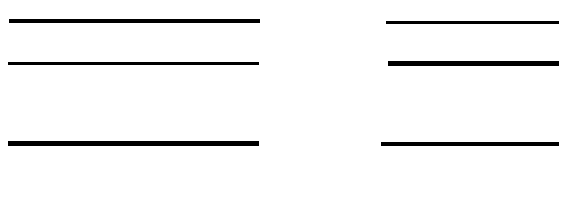

$\$ 36 \mathrm{~S}, \mathrm{OOO}$

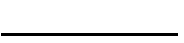

SUBTOTAL $\$ 1,905$, OOO 
1. ACTUAL PKODUCTION:

$\begin{array}{lcc}\text { SPECIES } & \text { A. POUNDS } & \text { B. PEKCENT } \\ \text { W. STHD } & 2,029 & - \\ \text { SK. CUT. } & 13,990 & - \\ \text { RES. TROUT } & 42,400 & - \\ & -\ldots \ldots .-\ldots & \\ \text { TOTAL } & 58,380 & -\end{array}$

2. THEOKETICAL PRODUCTION-- b a s ed on existing facilities:

- DENSITY FORMULA (.5 X L X VOL.)= $115,025 \mathrm{lb}: 1 \mathrm{~b} / \mathbf{c f} 2.7$

- F L O W FORMUAL ( F X L X CPM $)=$ $12,200 \quad 1 \mathrm{~b}: \mathbf{1 b} / \mathbf{c f} 0.3$

- AGENCY CKITERIA RANGE (.8 X VOL)= $\quad 33,6001 \mathrm{~b}$ and $(2 \times \mathrm{VOL})=84,00001 \mathrm{~b}$

3. FACTORS CONTKOLLING PKODUCTION:

A. POND VOL.: 42,000 cf

B. WATER: $1200 \mathrm{gpm}$

c. FISH BIOMASS:

i. rearing density

$-1 \mathbf{b} / \mathbf{c f} \quad 2.39$

-lb/gpm 48.7

MODIFICATION COMMENTS: None recommended. Land is available, but the water supply is limited.

* Currently used volumes

O Available Volumes 
HATCHEKY: HERMAN CREEK POND (OXBOW HATCHEKY) LOCATION CODE: 26A

1. ACTUAL PKODUCTION:

SPECIES A. POUNDS _... B. PEKCENT

TOTAL NO DATA AVAILABLE

2. THEORETICAL PRODUCITON-- based on existing facilities:

- ACENCY CKITEKIA KANGE (.8 X VOL)= 86,600 lo and

$(2 \mathrm{x}$ VOL) $216,400 \quad \mathrm{lb}$

3. FACTORS CONTROLLING PKODUCTION:

A. POND VOL.: $108,244 \mathrm{CF}$

B. WATER: $8976 \mathrm{CPM}$

MODIFICATION COMMENTS: SEE HATCHERY SUMMARY.

* Currently used volumes

(> Available Volumes 
1. ACTUAL PKODUCTION:

\author{
SPECIES \\ $\mathrm{COHO}$
}

TOTAL
A. POUNDS

NO DATA

- . . . . . . . . .

NO DATA
B. PEKCENT

100

2. THEOKETICAL PRODUCTION-- b a s ed on existing facilities:

- AGENCY CKITEKIA RANGE (.L) X VOL)= 11,848, OOO $1 \mathrm{~b}$ : and

$(2 \mathrm{x}$ VOL $)=28,000$, OUO $1 \mathrm{~b}:$

3. FACTORS CONTROLLLIGN PRODUCION1

A. POND V OL.: $14,810,040$ CY

B. WATEK: $2645.7--\mathbf{1 0 0 8 9 . 7}$ CPM

I enhance quality - temperature $* X *$

C. FISH BIOMASS

- a eration * $\mathrm{x}^{*}$

i increase density *X*

MODIFICATION COMMENTS: Modifications would include aeration

equiptment. Increased loading will perhaps require an increase in feed. Otherwise no modifications are recommended for

increased production.

* Volume of currently used ponds

( $>$ Volume of total available pond apace

$* \mathrm{X}^{*}$ Action item 
1. ACTUAL PKODUCTION:

$\begin{array}{lcc}\text { SPECIES } & \text { A. POUNDS } & \text { B. PEKCENT } \\ \text { S. STHD } & 14,500 & 36.1 \\ \text { W. STHD } & 25,800 & 63.9 \\ \text { KES. TKOUT } & \text { No Data } & - \\ \text { TOTAL } & 40,300 & -\end{array}$

2. THEOKETICAL PRODUCTION-- b a a d on existing facilities:

- DENSITY FOKMULA (.5 X L X VOL.) - $344,5001 \mathrm{~b}: 3.5$ lb/cf

- F L O W FORMULA ( F X L $\quad$ X $\quad$ OPM $)=\begin{array}{lllll}27,000 & \mathrm{lb}: & 0.3 & \mathbf{1 b} / \mathbf{c f}\end{array}$

- AGENCY CKITEKIA RANGE (.8 X VOL)= $78,000 \mathrm{lb}$ and $\quad(2 \times$ VOL $)=195,000 \quad l \quad b$

3. FACTORS CONTROLLINC PRODUCTION:

A. POND VOL.: 97,540 cf

B. WATEK: $2645.7-1008 Y .2 \mathrm{gpm}$

c. FISH BIOMASS:

iv. rearing density

$\begin{array}{lll}-1 \mathrm{~b} / \mathrm{CY} \quad 0.41 & \end{array}$

-lb/CPM 15.26

MODIFICATION COMMENTS: A number of the ponds need to be replaced. Perhaps they should be replaced with large rearing ponds. Recommend the consideration of the use of fall chinook to coincide with the availability of additional water.

* Currently used volumes

() Available Volumes 
1. ACTUAL PRODUCTION:

\section{SPECIES \\ $\mathrm{COHO}$}

TOTAL
A. POUNDS

49,450

49,450
8. PEKCENT

2. THEORETICAL PRODUCTION-- bas ed on existing facilities:

- D E N S I T Y FORMAULA (.5 X L X V O L . ) = 270,040 $1 \mathrm{~b}: 2.2$ 1D/cf

- FLOW FOKMULA ( F $\quad$ x L $\quad$ x CPI4)= $111,0421 \mathrm{~b}: 0.15 \mathrm{lb} / \mathrm{cf}$

- AGENCY CKITEKIA KANGE (.8 X VOL $)=98,0001 \mathrm{~b}$ and ( 2 x VOL) $-245, \&+001 \mathrm{~b}$

3. FACTORS CONTROLLING PRODUCITON:
A. POND VOL.: 122,920 cf
B. WATER: $2780.3 \mathrm{gpm}$
i. increase amnt. available $* X^{*}$
i i. reuse * $x^{*}$
iii.enhance quality - temperature * $X^{*}$
C. FISH BIOMASS: $-1 \mathrm{~b} / \mathrm{CF} \quad 0.40$
$-1 \mathrm{~b} / \mathrm{C}$ P M 17.8
iv. rearing density
C. FISH BIOMASS
i. rearing density
$-1 \mathbf{b} / \mathbf{c f} 0.40$
-lb/gpm 17.8

MODIFICATION COMMENTS: None recommended.

* Currently used volumes

(> Available volumes

$\mathrm{X}$ Action item 
1. ACTUAL PKODUCTION:

$\begin{array}{lrr}\text { SPECIES } & \text { A. POUNDS } & \text { B. PEKCENT } \\ \text { S. STHD } & \mathbf{5 4 , 1 7 0} & \\ \text { w. STHU } & 35,200 & 56.3 \\ \text { SK. CUT. } & 6,800 & 36.6 \\ \text { TOTAL } & 96,170 & \end{array}$

2. THEROETICAL PRODUCTIONbased on existing facilities:

- D E N S I T Y FORMULA (.5 X L X V O L .) = $194,600 \mathrm{lb}: 3.6 \mathrm{lb} / \mathrm{cf}$

- FLOW FORULA $\quad\left(\begin{array}{llllllll} & \text { F } & \text { L } & X & \text { Gl'M })=80,527 & \mathrm{lb}: & 1.51 & 1 \mathrm{~b} / \mathrm{cf}\end{array}\right.$

- AGENCY CRITEKIA RANGE (.8 X VOL)- $42,700 \quad$ lb and ( $2 \mathrm{x}$ VOL) $106,800 \quad 1 \mathrm{~b}$

3. FACTORS CONTKOLLINC PRODUCTION:

A. POND VOL.: *53,392 c $\mathrm{f}$

i. new facilities $* X *$

B. WATER : $7488.8 \mathrm{CPM}$

i. increase amnt. available $* X^{*}$

i i. reuse 1005 (seriel)

c. FISH BIOMASSS

i. decrease density $* X *$

iv. rearing density

$-1 \mathrm{~b} / \mathrm{CP} 1 \quad . \quad 8$

$-1 \mathrm{~b} / \mathrm{GYM} 12.8$

MODIFICATION COMMENTS: Recommend the replacement of (10) 4'x30' raceways with (2) 20'x801x4' ponds. The room and water exists for up to a 1 acre rearing pond on the site. The water source would be from the river for 8 months of the year, and augmented by reuse for 4 months.

4. ESTIMATED INCREASED PRODUCITON ( $\mathrm{T}$ o T A L ) : $47,400 \quad \mathbf{l b}$.

5. ESTIMATED CONSTRUCTIO COSTS: $\$ 620,000$.

6. ESTIMATED INCKEASES IN OPERATIONS COSTS: Would include costs for $71,100 \mathrm{lb}$ of feed and $1 / 2 \mathrm{man}$ year of labor.

* Volume of currently usea ponds

( ) Volume of total available pond space

$\mathrm{X}$ Action Item 
ESTIMATED PRODUCTION INCREASE, CONSTRUCTION COSTS, AND OPERATIONAL COSTS BASED ON HATCHEKY MANAGERS IMPROVEMENT IDEAS HATCHEKY: SKAMANIA LOCATION CODE: 29 PKODUCTION INCREASE: 47,400 LBS. NAME: FARR/PW CONSTKUCTION COSTS:
A. FACILITIES

\begin{tabular}{ll} 
l.INCUBATORS & \\
\cline { 2 - 2 } 2.STAKT TANKS & \\
3.REARING & \\
RACEWAYS & ZO'XkiO'X3' \\
PONDS & 35U'X6O'X4' \\
4,REMOVAL OF & EXISTING PONDS \\
5.AEKATOKS & \\
6.BIOFILTERS & -
\end{tabular}

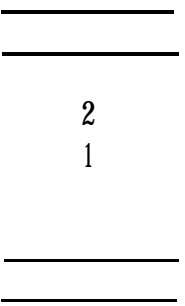

SIZE

NUMBER

COSTS

B. WATER SYSTEMS:
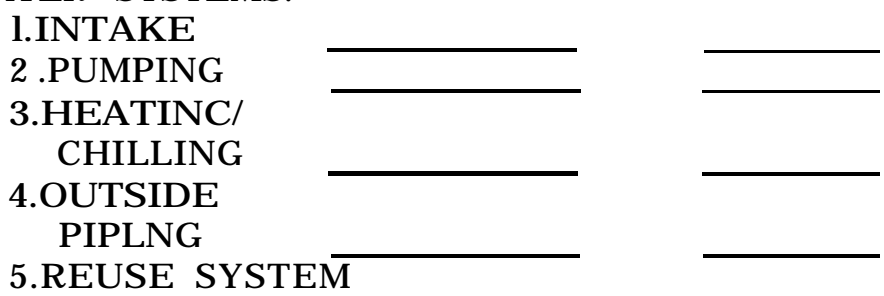

$\$ 65, \mathrm{OOc}$,

$\$ 180,001)$

$\$ 15,000$

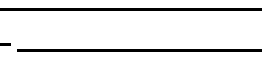

B. WATERE

2 .PUMPING

HEATINC/

OUTSIDE

PIPLNG

5.REUSE SYSTEM

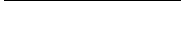

$\$ 170,000$

$\$ 50$, OUO

c . BUILDINGS

1.HATCHING

2 .PUMP HOUSE

3.FARAGE

4,SHOP

5.REFRIDGERATIO

6,STORAGE

7.RESIDENCE
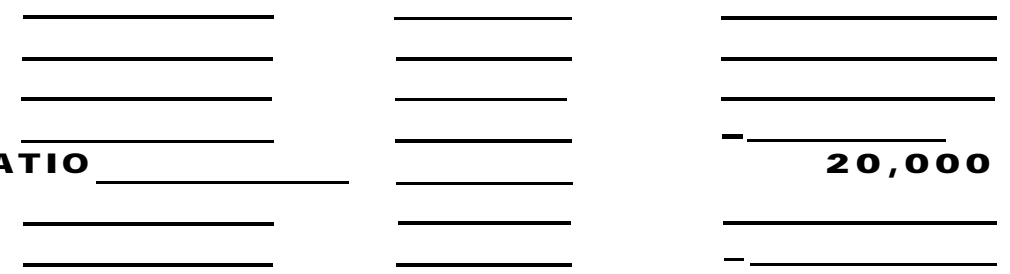

SUBTOTAL $\$ 620,000$ 
1. ACTUAL PRODUCTION:

\section{SPECIES \\ S P . CHINOOK \\ S. STHD}

TOTAL
A. POUNDS
34,500
29,100
B. PEKCENT
54.3
45.7

2. THEORETICAL PRODUCITON-- bas ed on existing facilities:

- D E N S I T Y FIRNYKA (.5 X L X V O L . ) = $232,7501 \mathrm{~b}: 3.8 \mathrm{lb} / \mathbf{c f}$

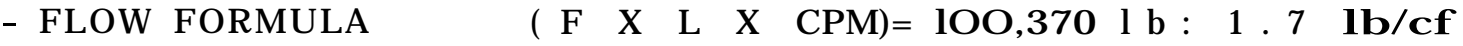

- AgENCY C K I T E K I A RANGE (.8 X VOL)- $48,5001 \mathrm{~b}$ and

( $2 \mathrm{x}$ VOL) $121,2001 \mathrm{~b}$

3. FACTOKS CONTROLLING PKODUCTION:
A. POND VOL.: *60,590 (81,9OU) CF
i. new facilities $* X^{*}$
B. WATEK: 9013.5 GPM
C. FISH BIOMASS:
IV. rearing density
$-1 \mathrm{~b} / \mathrm{CY} \quad 1.05$
$-1 \mathrm{~b} / \mathrm{CPM} \quad 7.06$

MODIFICATION COMMENTS: We recommend the construction of a new adult holding pond, retrofitting of the old adult holding pond for use as a rearing pond. In addition, the space and water exists for the construction and operation of new rearing ponds.

4. ESTIMATED INCREASED PKODUCTION (TOTAL): 40,000 1 b.

5. ESTIMATED CONSTRUCTION COSTS: $\$ 740,000$.

6. ESTIMATED INCREASED IN OPERATIONS COSTS: Operations costs would include that for an additional 60,000 lb of feed and $1 / 2$ man years of labor.

* Volume of currently used ponds

( ) Volume of total available pond space

$\mathrm{X}$ Action item 
ESTIMATED PRODUCTION INCKEASE, CONSTKUCTION COSTS, AND OA'EKATIONAL COSTS BASED ON HATCHEKY MANAGERS IMPKOVEMENT

HATCHEKY: SO. SANTIAM

LOCATION CODE: $30 \mathrm{~A}$

[RPDICTOPM INCREASE: 40,000 LB. NAME : FARR/PW

CONSTRUCTION COSTS:

A. FACILITIES

SIZE

NUMBEK

COSTS

1.INCUBATOKS

2.START TANKS

3.HEAROMG

KACEWAYS

PONDS

4.HOLDINC

20X80X3'

150X20X6

5.AEKATOKS

6.BIOFILTERS

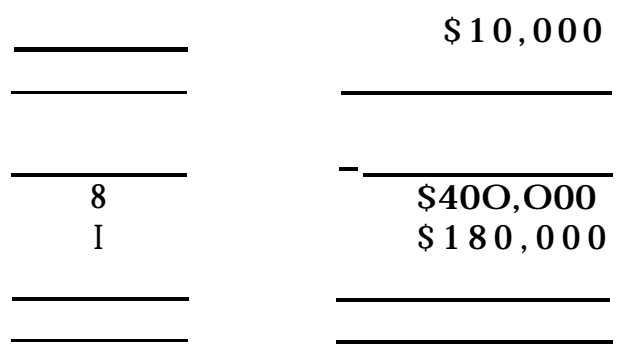

B. WATEK SYSTEMS:

1.INTAKE

2.PUMPING

3.HEATING/

CHILLING

4.0UTSIDE

PIPING
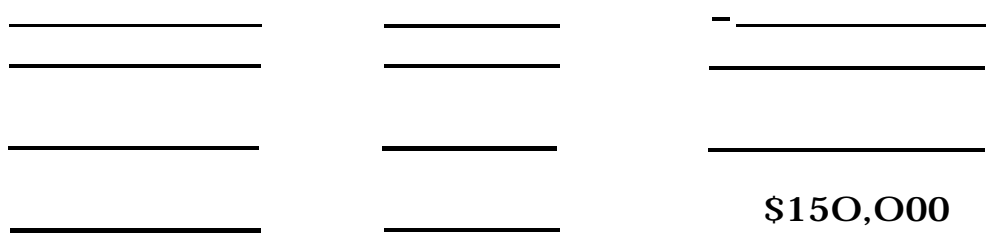

c . BUILDINGS

1 HATCHING

2.PUMP HOUSE

3.GARAGE

4.SHOP

5 . REFRIDGE RATION

6. STOKAGE

7. KESIDENC E
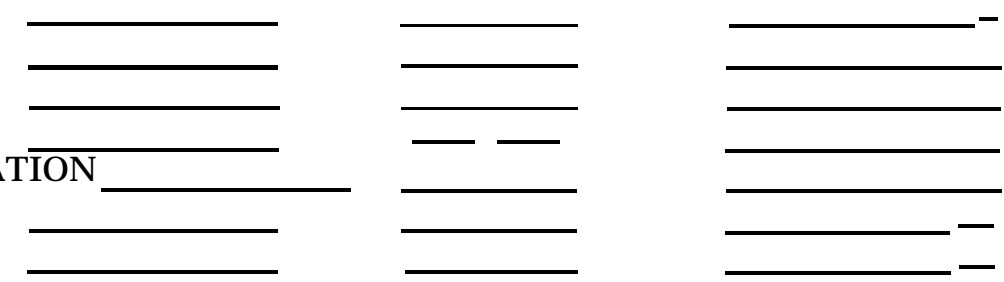

SUBTOTAL $\$ 740,000$ 
1. ACTUAL PKODUCTION:
SPECIES
F. CHINOOK
A. POUNDS
B PEKCENT
81,200
100
TOTAL
81,200

2. THEORETICAL PRODUCTION-- based on existing facilities:

- D E N S I T Y FORMULA (.5 X L X V O L . ) = 6,708,2UU l b: $1.75 \mathrm{lb} / \mathbf{c f}$

- F L O W FORMUAL ( $\mathrm{Y}$ x L $\mathrm{x}$ GPM)- $116,000 \quad 1 \mathrm{~b}: 0.03 \mathrm{lb} / \mathbf{c f}$

- AGENCY CKITEKIA RANGE (.8 X VOL)= 3,066,600 lb

3. FACTORS CONTKOLLING PRODUCTION;

A. POND VOL.: 3,833,280 c $\mathrm{f}$

i. facilities not fully utilized *X*

b. WATER: $22421.5 \mathrm{CPM}$

i. enhance quality

- a e r ation $* X^{*}$

C. FISH BIOMASS:

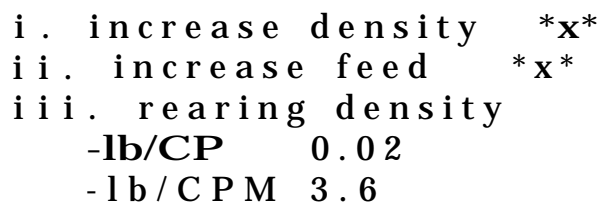

MODIFICATION COMMENTS: There is no potential for physical plant expansion at this site. The production of this facility apparently could be increased by one third without any additional water or construction. This can be accomplished with aeration and increased supplemental feed.

4. ESTIMATED INCREASED P R O D U C T I O N (TOTAL): 27,000 $1 \mathrm{~b}$.

5. ESTIMATED INCKEASES IN IOERATIONS COSTS: Include the costs of $40,200 \mathrm{lb}$ of feed and one half man year of labor.

* Volume of currently used ponds

( ) Volume of total available pond space

$\mathrm{X}$ Action item 
1. ACTUAL PKODUCTION:

SPECIES
SP. CHINOOK
F. CHINOOK
co HO

TOTAL

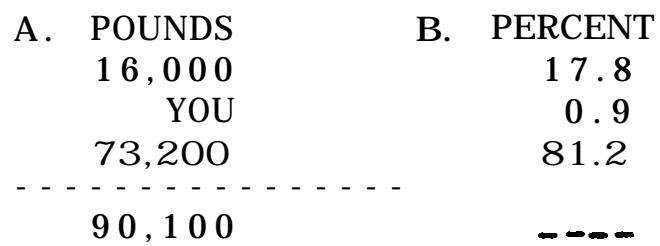

2. THEORETICAL PRODUCTION--based on existing facilities:

- DENSITY YOKMULA (.5 X L X VOL.)= 179,200 lb: 2 1b/cf

- FLOW FORMULA (Y X L X GPM)' 48,000-77,000 lb: $0.6-.91 \mathrm{~b} / \mathrm{cf}$

- AGENCY CKITERIA RANGE $(.8 \mathrm{X}$ VOL $)=65,800 \mathrm{l} \mathrm{b}$ and ( 2 x VOL) $164,4001 \mathrm{~b}$

3. FACTOKS CONTKOLLING PRODUCITON;

A. POND VOL.: $82,200 \mathrm{cf}$

i. new facilities $* X^{*}$

B. WATER: 7408.1-10367.7 GPM

c. FISH BIOMASS:

iv. rearing density

$-1 b / C P 1.1$

$-\mathrm{lb} / \mathrm{CPM} \quad 12.2$

MODIFICATION COMMENTS: The construction of a rearing pond at the lower end of Speelyai Creek is suggested as a means of increasing rearing space (see Hatchery Summary).

4. eSTIMATED INCREASED PRODUCION ( TotaL): $12,0001 \mathrm{~b}$

5 ESTIMATED CONSTKUCTION COSTS: $\$ 50,000$

6. ESTIMATED INCREASES IN OPEKATIONS COSTS: costs to include those for $18,000 \mathrm{lb}$ of feed and $1 / 2 \mathrm{man}$ year of labor.

* Volume of currently used ponds

( ) Volume of total available pond space.

$\mathrm{X}$ Action item 
ESTIMATED PRODUCITON INCKEASE, CONSTRUCTION COSTS, AND OPEKATIONAL COSTS BASED ON HATCHEKY MANAGERS IMPKOVEMENT IDEAS

HATCHEKY: SPEELYAI

PKODUCTION INCREASE:

LOCATION CODE: 31

CONSTRUCTION COSTS:

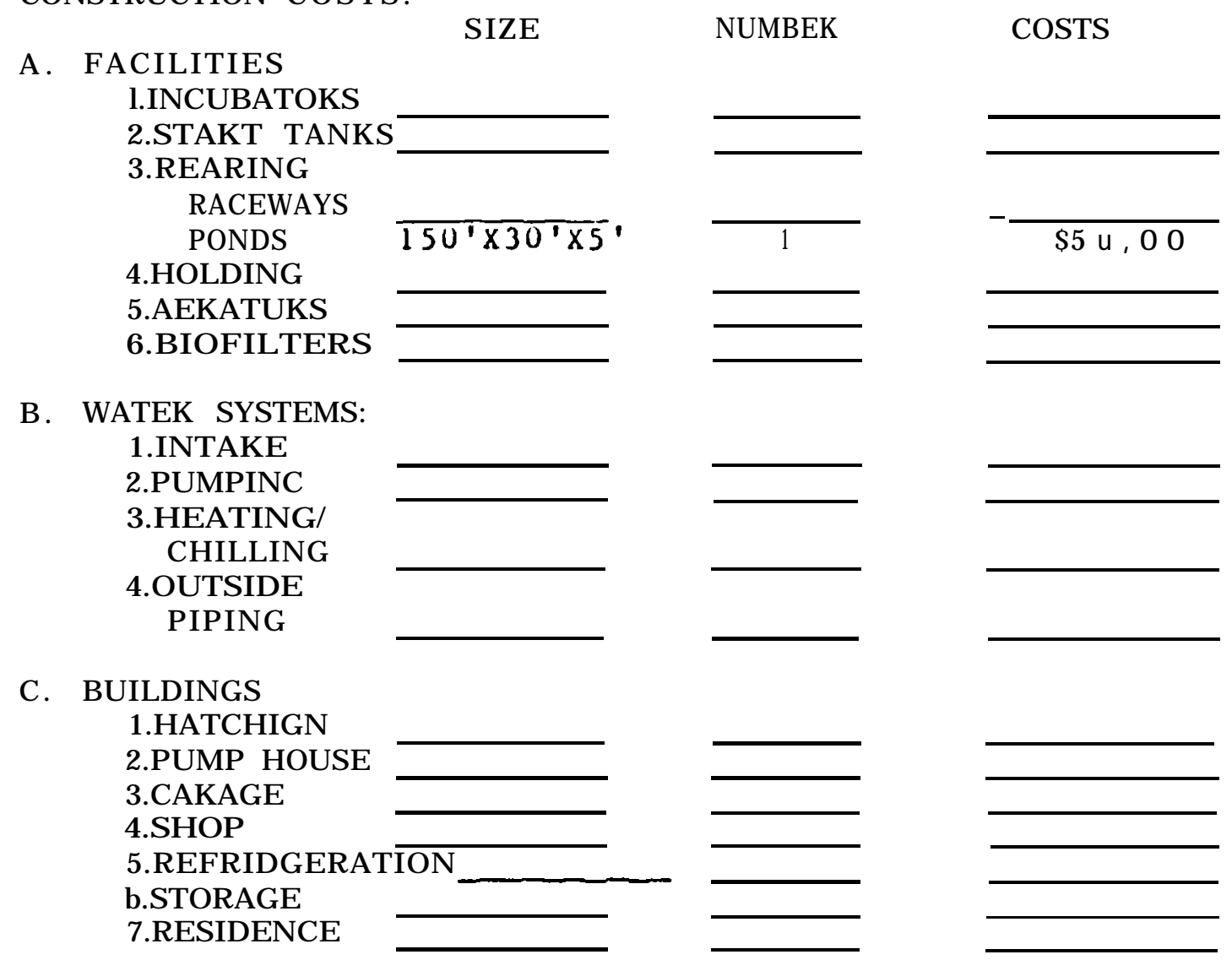

SUBTOTAL $\$ 50,000$ 
HATCHERY: TOUTLE RIVEK HATCHERY (BEAK SPKINGS) LOCATION CODE: 32

1. ACTUAL PRODUCTION:

SPECIES

A. POUNDS B. PEKCENT

NO PKODUCTION SINCE 1980

2. THEORETICAL PRODUCDTION--based on existing facilities:

- AGENCY CKITERIA RANGE (.8 X VOL)= 259,201) LB

and ( 2 x VOL> 648,000 LB

3. PACTOKS CONTKOLLING PRODUCITON;

A. POND VOL.: 324, OUU c f ( t o t a l a t o l d s i t e )

d WATE'K: UNKNOWN

C. FISH BIOMASS: UNKNOWN

MODIFICASTION COMMENTS: Suggest that the facility be rebuilt and runs reestablished (s e SUMMARY for hatchery). We have been informed my WDF that the agency intends to reactivate the Bear Springs facility to produce, Initially, 140,000 smolt coho at 20/1b.

* Currently used volumes

O Available Volumes 
1. ACTUAL PRODUCTION:

$$
\begin{array}{ll}
\multicolumn{2}{c}{\text { SPECIES }} \\
\text { S. } & \text { STHD } \\
\text { W. } & \text { STHD } \\
\text { SK. } & \text { CUT. }
\end{array}
$$

TOTAL
A. POUNDS
IN,3UO
1,200
1,200
B. PEKCENT
98.0
0.9
0.9

121,700

2. THEOKETICAL PRODUCITON-- based on existing facilities:

- DENSITY FOKMULA (.5 X L X VOL.) = 1,014,500 lb: 2.18 1b/cf

- PLOW POKMULA ( F X L X GPM)- 13,000 l b: 0.03 1b/cf

- AGENCY CKITERIA RANGE (.8 X VOL)= $371,6001 \mathrm{~b}$ and $(2 \times$ VOL $)=928.9001 \mathrm{~b}$

3. FACTORS CONTROLLING PKODUCTION:

A. POND VOL.: *464,500 c f

1. new facilities $* X *$

B. WATER: $1058.3-1883.4 \mathrm{CPM}$

i. increase amnt. available $* X^{*}$

i i. reuse $90 \%$

C. FISH BIOMASS:

I. rearing density

$-1 \mathrm{~b} / \mathrm{CF} \quad 0.26$

-lb/GPM 64.6

MODIFICATION COMMENTS: Additional water is needed (see $\mathrm{Hatchery}$ Summary). Space exists for facility expansion, however no expansion should be attempted without additional water or the installation of recirculation facilities. Additional water could be obtained by drilling new wells or constructing recirculation facilities.

4.ESTIMATED INCREASED P R O D U C T I O N (TOTAL): 60,000 $1 \mathrm{~b}$.

5. ESTIMATED CONSTRUCTION COSTS: $\$ 1,12 \mathrm{O}, \mathrm{UUO}$.

6. ESTIMATED INCREASES IN OPEKATIONS COSTS: Include the cost of $90,000 \mathrm{lb}$ of feed and one man year labor.

* Volume of currently used ponds

( ) Volume of total available pond space

$\mathrm{X}$ Action item 
ESTIMATED PKODUCTION INCKEASE, CONSTKLJCTION COSTS, AND OPERATIONAL COSTS BASED ON HATCHERY MANAGEKS IMFKOVEMENT IDEAS

HATCHEKY: VANCOUVEK TROUT LOCATION CODE: 33 PKODUCTION INCREASE: 60,000 LBS. NAME: FAKK/PW

CONSTRUCITON COSTS:

A. FACILITIES

1 INCUBATORS

2. START TANKS

3, REARITN

KACEWAYS

PONDS

SIZE

NUMBEK

Costs

4.HOLDING

5.AEKATOKS

6.BIOFILTERA

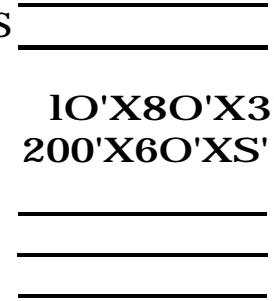

6 STAKS

15,00

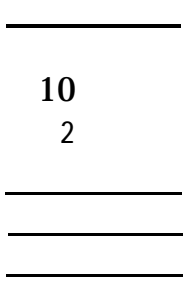

40,000

$\$ 2565,000$

$\$ 180,000$

B. WATER SYSTEMS:

1.INTAKE

2.PUMPING

3.HEATING/
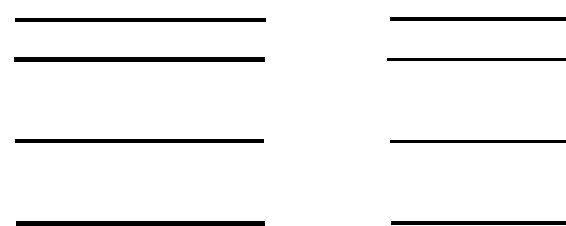

$\$ 350,000$

CHILLING

4.0UTSIDE

PIPING

C. BUILDINGS

1.HATCHING

2, PUMP HOUSE

3.GARAGE

4.SHOP

5.REFRIFGERAT $\overline{\mathrm{ION}}$

6.STORAGE

7.RESIDENCE ( $\overline{\text { FENCLNG) }}$
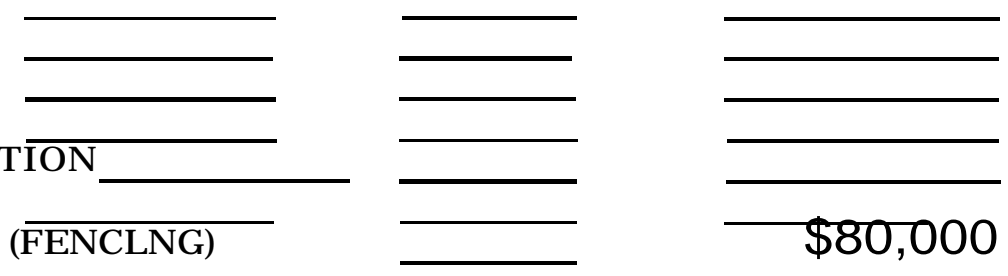

$\$ 1,120,000$ 
1. ACTUAL PRODUCTIO:

SPECIES
F. CHINOOK
COHO

TOTAL
A. POUNDS
81,300
94,400
B. PERCENT
46.3
53.7

2. THEORETICAL PRODUCTOIN-- bas ed on existing facilities:

- DENSITY FOKMULA (.5 X L X VOL.) - $907,7001 \mathrm{~b}: 1.67 \mathrm{lb} / \mathbf{c f}$

- FLOW FOKMULA ( F X L X GFM)- $127,5731 \mathrm{~b}: 0.23 \mathrm{lb} / \mathrm{cf}$

- AGÉNCY C KI T E R I A RANGE (.8 X VOL)- $384,6001 \mathrm{~b}$
and
$\left(\begin{array}{lll}2 & \mathrm{x} & \mathrm{Q}\end{array}\right.$
$961,60 \mathrm{U} \mathrm{l} \mathrm{b}$

3. FACTORS CONTKOLLING PRODUCITON:
A. POND VOL.: 543,800 c f
B. WATEK: $22493.3-22879 \mathrm{gpm}$

i. reuse $100 \%$

c. FISH BIOMASS:

i rearing density

$-1 \mathrm{~b} / \mathrm{CY} \quad 0.32$

-lb/GPM $7 \quad$. 8

MODIFICATION COMMENTS: Additional water would help but is not available all year. Perhaps fall chinook production could be increased when water is available. This would require additional pumps. Part of Bayles Creek could be diverted to raceways.

* Currently used volumes

(> Available Volumes

$X$ Action item 
1. ACTUAL PKODUCTION:

\section{SPECIES \\ SP. CHINOOK \\ s. STHD}

TOTAL
A. POUNDS
74,200
B. PEKCENT
76.7
$22,600 \quad 23.3$

2. THEOKETICAL PRODUCTION--based on existing facilities:

- DENSITY FOKMULA (.5 X L X VOL.) = $652,552 \mathrm{lb}: 2.4 \mathrm{lb} / \mathrm{cf}$

- FLOW FOKMULA ( F X L X GPM)=148,738 l b: 0.55 lb/cf

- AGENCY CKITEKIA RANGE (.8 X VOL $>=215,0001 \mathrm{~b}$ and

3. FACTOKS CONTKOLLING PKODUCTION:

A. POND VOL.: $\star 268,800$ cf

i. new facilities $* X^{*}$

B. WATER: 20,540 gpm

i Increase amnt. available $* X^{*}$

c. FISH BIOMASS

1. rearing density

$-1 \mathrm{~b} / \mathrm{CF} \quad 0.36$

$-1 \mathrm{~b} / \mathrm{GPM} \quad 4.7$

MODIFICATION COMMENTS: Perhaps density could be increased. With additional water the production could be significantly

increased. The use of fall chinook should be considered. The intake structure requires improvement (see Hatchery Summary).

The major differences between actual and estimated

production are probably the result of insufficient adult returns, high adult pre-spawning mortality, and/or insufficient young to fill to capacity.

4.ESTIMATED INCREASED PKODUCTION (TOTAL): 90,000 $1 \mathrm{~b}$.

5. ESTIMATED CONSTSSRUCITON COSTS: $\$ \mathbf{1 , 0 3 7 , 0 0 0 .}$

6. ESTIMATED INCKEASES IN OPERATIONS COSTS: Include $135,000 \mathrm{lb}$ of feed and one man year labor.

* Volume of currently used ponds

( ) Volume of total available pond space

$\mathrm{X}$ Action item 
ESTIMATED PRODUCTION INCREASE, CONSTKUCTION COSTS, AND OPERATIONAL COSTS BASED ON HATCHEKY MANAGERS IMPROVEMENT IDEAS HATCHEKY: WILLAMETTE LOCATION CODE: $35 \mathrm{~A}$ PKODUCTION INCREASE: 90,000 LBS. NAME: FARRR/PW CONSTKUCTION COSTS:

A. FACILITIES SIZE

NUMBEK COSTS

1.INCUBATORS 2.STAKT TANKS 3.REAKING KACEWAYS PONDS

4.HOLDING 5.AERATOKS 6.BIOFILTERS

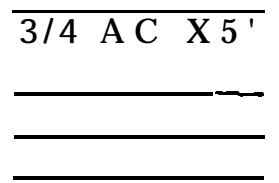

B. WATEK SYSTEMS:

1.INTAKE 2.PUMPING 3.HEATING/ CHILLING 4.0UTSIDE PIPING
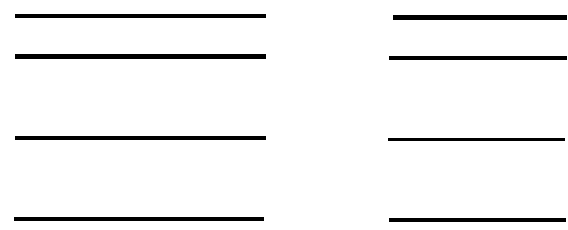

$\$ 175,000$ $\$ 22,500$
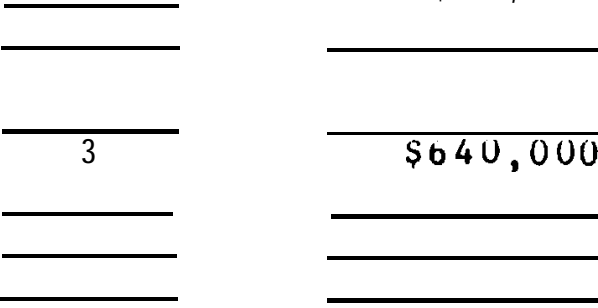

$\$ 640,000$
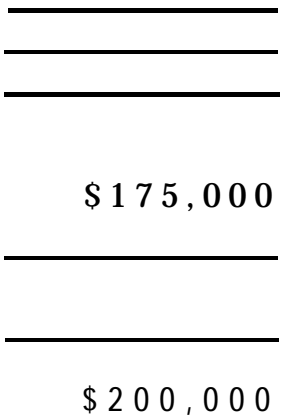

c . BUILDINGS

1.HATCHING 2.PUMP HOUSE

3 .GARAGE SHOP

5,REFRIDGERATION

6.STORAGE

7.RESIDENCE
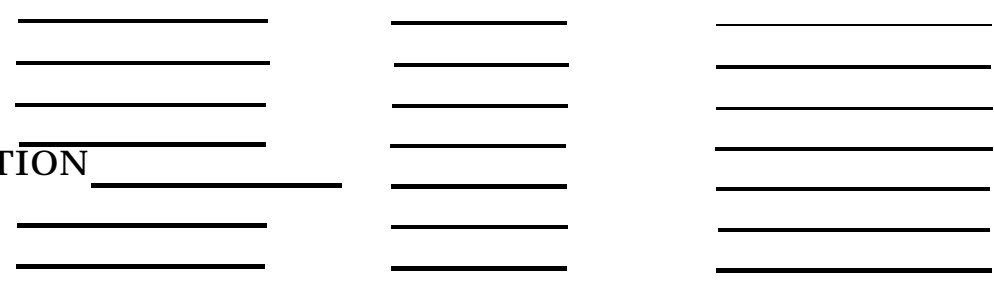

SUBTOTAL $\$ \mathbf{1 , 0 3 7 , 5 0 0}$ 
1. ACTUAL PKODUCTION:

$\begin{array}{lccc}\text { SPECIES } & \text { A. POUNDS } & \text { B. PERCENT } \\ \text { SP CHINOOK } & 20,900 & 100 \\ \text { TOTAL } & 20,901) & \end{array}$

2. THEORETICAL PRODUCITON-- bas ed on existing facilities:

- D E N S I T Y ,FORMULA (.5 X L X V O L.) $=599,3001 \mathrm{~b}: 3.95 \mathrm{lb} / \mathrm{cf}$

- FLOW FORMULA ( F X L X CPM) $=354,4001 \mathrm{~b}: 2.34 \mathrm{lb} / \mathrm{cf}$

- AGENCY CKITERIA RANCE (8. X VOL) $=121,400 \quad$ l b and

$(2 \times \mathrm{VOL})=3133,400 \mathrm{lb}$

3. FACTORS CONTROLLING PKODUCTION:

A. POND VOL.: 151,700 $\mathrm{cf}$

i.

B. WATEK: $30941.7 \mathrm{~g} \mathrm{pm}$

C. FISH BIOMASS:

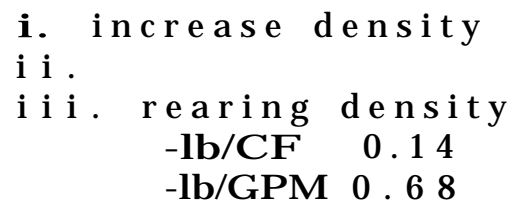

MODIFICATION COMMENTS: Apparently, density could be increased. Supplemental feed should be increased as a percent of fish biom ass.

The major differences between actual production and estimated production is probably the result of high predation levels and lower than necessary supplemental feeding.

4.ESTIMATEl.J INCKEASED PKODUCTION (TOTAL): 2 0,000 1

5.

INCREASED IN OPERATIONS COSTS: Include costs for 30,000 lb of feed and 1/2 man year labor.

( ) Volume of total available pond space 
1. ACTUAL PKODUCTLON:

$\begin{array}{lcc}\text { SPECIES } & \text { A. POUNDS } & \text { B. PEKCENT } \\ \text { SP. CHINOOK } & \mathbf{1 1 1 , 8 0 0} & 70.5 \\ \text { COHO } & 28,000 & 29.5 \\ & -\ldots-\ldots & \\ \text { TOTAL } & 139,900 & -\cdots\end{array}$

2. THEORETICAL PRODUCTION-- bas ed on existing facilities:

- DENSITY FOKMULA (.5 X L X VOL.)=354,701) $1 \mathrm{~b}: 2.6 \mathrm{lb} / \mathrm{cf}$

- FLOW FOKMULA ( $\mathrm{Y}$ X L X GPM) $302,700 \quad 1 \mathrm{~b}: 2.21 \mathrm{lb} / \mathbf{c f}$

- AGENCY CRTERIA RANGE (.8 X and $(2 \mathrm{x}$ VOL) $274,400 \quad 1 \mathrm{~b}$

3. FACTORS CONTROLLING PRODUCTION:
A. POND VOL.: $* 137,200$
i.
B. WATEK:
i.
$100 \%$
* X*
1 .

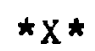
$-1 \mathrm{~b} / \mathrm{CE}$

Fish Wildife

4.ESTIMATED INCREASED PRODUCTION (TOTAL): 96,000

$\$ 1,810,000$. 
ESTIMATED YKODUCTION INCREASE, CONSTKUCTION COSTS, AND OPERATIONAL C O S T S BASED O N HATCHERY MANAGERS IMPROVEMENT IDEAS HATCHERY: CARSON NFH LOCATION CODE: 36 PRODUCITON INCKEASE: 96,000 LBS. NAME FARR/PW CONSTRUCTION COSTS:

A. FACILITIES SIZE NUMBER $\cos \cos ^{-1}$ 1.INCUBATOKS 2.START TANKS 3.REARIGN KACEWAYS PONDS

4. HOLDIGN 5,AERATORS 6,BIOFILTERS

\section{O'XtsO'X3'}

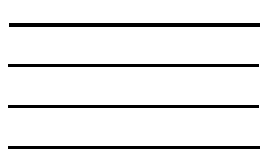

B. WATER SYSTEM :

1.INTAKE (TYEE CKEEK;)

2.PUMPING

3.HETING/

CHILLING

4.0UTSIDE PIPING

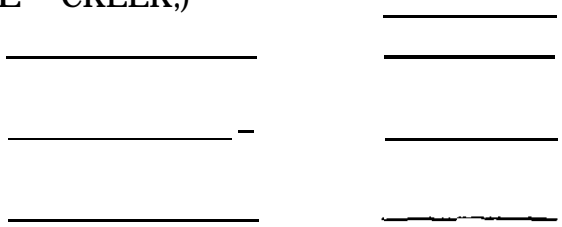

5.REUSE

C . BUILL)INC;S

1.HATCHING

2 .PUMP HOUSE

3.GARAGE

4 SHOP

5.REFRIDGERATION

6.STOKACE

7.RESIDENCE

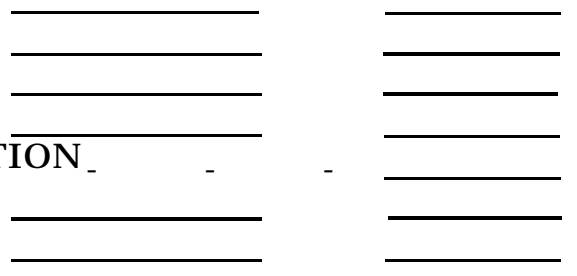

$\$ 25,000$
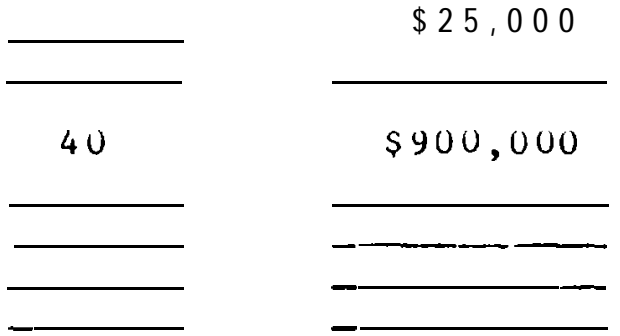

$\$ 85,000$

SUBTOTAL $\$ 1,810,000$

$\$ 400,000$

$\$ 250,000$

$\$ 150,000$

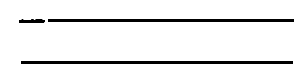


1. ACTUAL PRODUCTION:

SPECIES
KES. TKUUT

TOTAL
A. POUNDS NO DATA

B. PEKCENT

100

2. THERORETICAL PRODUCTION-- b a s ed on existing facilities: -AGENCY CKITEKIA RANGE (.8 X VOL $>=96,000 \mathrm{lb}$ and
$(2 \mathrm{x}$ VOL $)-240,000$ । b

3. FACTORS CONTROLLING PRODUCTION

A. POND V O L . : 120,000 CF

1. new facilities * $x^{*}$

B. WATEK: NO DATA

MODIFICATION COMMENTS: This hatchery produces exclusively resident trout for the sport fishery. three high dams are downstream of THS facility; fish passage facilities are inadequate for anadromous salmonid adults to return to this facility. Water and space are available for expansion projects. None recommended.

* Volume of currently used ponds

( > Volume of total available pond space

X Action item 
1. ACTUAL PKODUCTLON:

\author{
SPECIES \\ KES. TKOUT
}

TOTAL
A. POUNDS NO DATA

B. PEKCENT

100
NO DATA

2. THEORETICAL PRODUCTION-- based on existing facilities and: -AGENCY CKITEKIA KANGE $(.8 \mathrm{X}$ VOL $)=\begin{array}{lllllll}2 & 5,6 & 0 & 0 & 1 & \mathrm{~b}\end{array}$ and $\left.\left(\begin{array}{lll}2 & \mathrm{X} & \mathrm{VOL}\end{array}\right)=64,001\right) \quad \mathrm{b}$

3. FACTOKS CONTKOLLINC PRODUCITON:
A. POND VoL.: 32,000 CF
i new facilities $*^{*}$
WATEK: 4500 GPM

MODIFICATION COMMENTS: Recommended modification 6 are based upon 1978 facilities report (Gray and osborne, Inc. P.S., consulting engineers, Yakima, Washington, 1978) which would incorporate facilities for rearing steelhead trout.

4,ESTIMATED INCREASED PKODUCTION (TOTAL): 27,300 Ib

5. ESTIMATED CONSTKUCTION COSTS: $\$ 3,500,000$

6. ESTIMATED INCREASES IN OPEKATIONS COSTS: Include the cost of $41,000 \mathrm{lb}$ of feed and $1 / 2 \mathrm{man}$ year.

* Volume of currently used pond 6

( > Volume of total available pond space

X Action item 
ESTIMATED PKOIJUCTION INCREASE, CONSTRUCTION COSTS, AND OPERATIONAL COSTS BASED ON HATCHEKY MANAGEKS IMPROVEMENT IDEAS

HATCHEKY: GOLDENDALE TKOUT LOCATION CODE: 38

PRODUCTION INCREASE : 27,301) LBS. NAME : FARR/PW

CONSTKUCTION COSTS:

A. FACILITIES

SIZE

NUMBEK

COSTS

1.INCUBATORS

2.START TANKS

3.REARING

KACEWAY‘S

PONDS

4. HOLDING

5 . AEKATORS

6. BIOFILTE KS
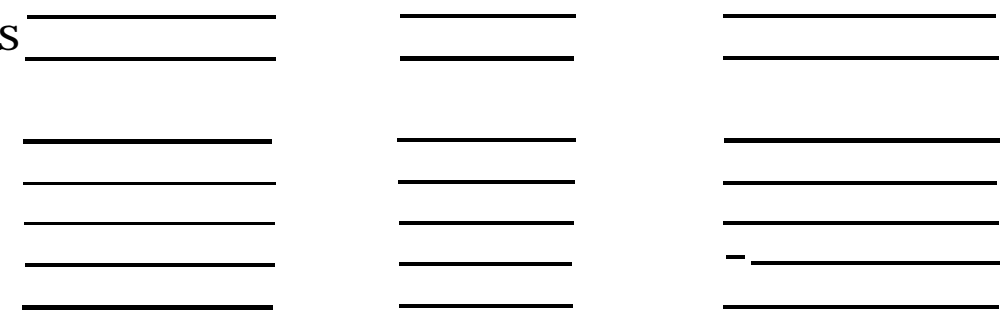

B. WATEK SYSTEMS:

1.INTAKE

2.PUMPINC

3.HEATING/

CHILLING

4.0UTSIDE

PIPING

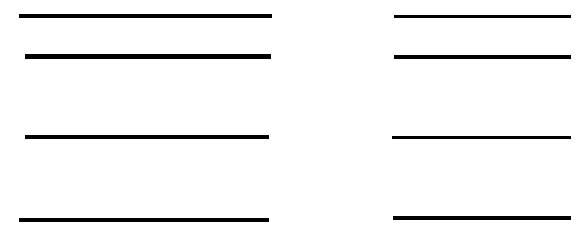

C. BUILDINGS

1.HATCHINC

2.PUMP HOUSE

3.GARAGE

4.SHOP

5.REFRIDGERATION

6.STORAGE

7.RESIFENCE
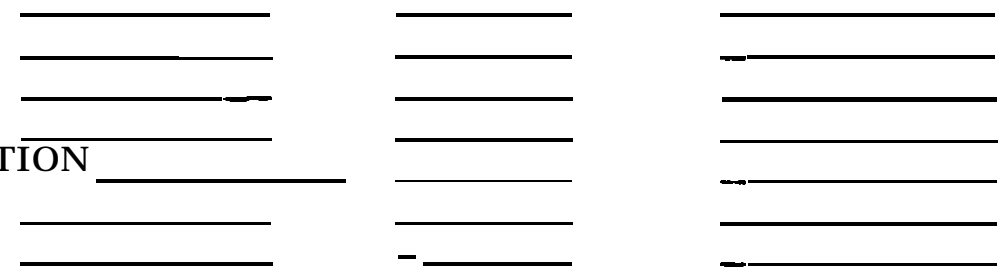

SUBTOTAL $\$ 3,500,000$

* SEE HATCHEKY SUMMAKY, TAKEN FROM WDG FACILITIES PLAN. 
1. ACTUAL PRODUCTION:
SPECIES
A. POUNDS
5730
$-\ldots \ldots$
$-\ldots . .$.
B. PERCNET
S. STHD
?
TOTAL
UNKNOWN

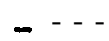

2. THEORETICAL PRODUCTION-- bas ed on existing facilities and:

-DENSITY FOKMULA $\quad t .5 \times \mathrm{L} \times \mathrm{VOL}.)=862,400 \mathrm{lb}: 3.85 \mathrm{lb} / \mathbf{c f}$

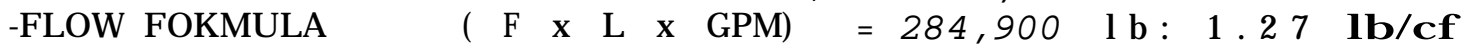

-AGENCY CKITEKIA KANCE $(.8 \mathrm{X}$ VOL $)=179,200 \mathrm{lb}$

and $(2 \mathrm{x}$ VOL $)=448,0001 \mathrm{~b}$

3. FACTORS CONTROLLING PRODUCTION:
A. POND VOL.: 224,000 CF

B. WATEK: 24663.7 GPM

MODIFICATION COMMENTS: This is a new facility and while ample land and additional water are available, further expansion is not an issue. The facility is apparently not up to full production yet.

* Volume of currently used ponds

( $>$ Volume of total available pond space

$X$ Action Item 
1. ACTUAL PRODUCTION:

$\begin{array}{ll}\text { SPECIES } \\ \text { SY. } & \text { CHINOOK } \\ \mathrm{F} . & \text { CHINOOK } \\ \text { CUHO } & \end{array}$

TOTAL
A. POUNDS
65,100
B. PERCNET
36.9
31.3
55,900
31.7
- . . . . . . . . .
176,000

2. THEORETICAL PKODUCTIUN--based on existing facilities and:

- DENSI T Y FORMULA (.5 x L x VOL. $=685,3001 \mathrm{~b}: 2.27 \mathrm{lb} / \mathrm{cf}$

- F L O W FOKMULA ( F $\quad$ X $\quad$ L $\quad X \quad$ CPM $)=65,000 \quad 1 \mathrm{lb}: 0.22 \quad 1 \mathrm{~b} / \mathrm{cf}$

- A G E N C Y C K I T E K I A KANGE (.8 X VOL) $=241,4$ OU $1 \mathrm{~b}$ and $(2 \times$ VOL $)=630,500 \quad l \quad b$

3. FACTORS CUNTKOLLINC PRODUCITON:
A. POND VOL.: " 301,760 cf
B, WATEK: $4977.6-7982.1 \mathrm{gpm}$ 1 reuse: (100X)
c. FISH tiIOMASS
i. rearing density:
$-1 b / c f \quad 0.58$
$-1 \mathrm{~b} / \mathrm{gpm} 35.4$

MODIFICATION COMMENTS: Need more water and it is unavailable, except from the river. Water resources are presently being used twice $(100 \%$ blo reuse). No expansion is possible. None recommended.

\footnotetext{
* Volume of currently used ponds ( > Volume of total available pond space

$X$ Action item
} 
1. ACTUAL PKODUCTION:

\author{
SPECIES \\ SP. CHINOOK \\ F. CHINOOK
}

TOTAL
A. POUNDS

$$
32,300
$$$$
89,000
$$$$
\text { - . - . - }
$$

121,300
B. PERCENT

26.6

73.4

2. THEORETICAL PRODUCTION-- based on existing facilities and:

- DENSITY FOKMULA (.5 X L X VOL.) = 365,400 lb: 3.9 1D/Cf

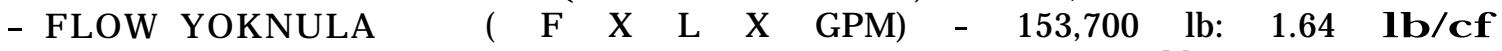

- AGENCY CKITEKIA KANGE (.8 X VOL)- $74,9001 \mathrm{~b}$ and

$(2 \mathrm{x}$ VOL $)=187,400 \quad 1 \mathrm{~b}$

3. FACTORS CONTKOLLING PKODUCTION:
A. POND VOL.: "93,710 (105,960) cf
B. WATBK: $26278 \mathrm{gpm}$
C. FISH BIOMASS:
i. rearing density:
-lb/CF 1.23
-lb/CPM 4.62

MODIFICATION COMMENTS: At c a pacity, none recommended.

* Volume of currently used ponds

( ) Volume of total available pond space 
1. ACTUAL PKODUCTION:

SPECIES
s . STHD

TOTAL
A. POUNDS

46,300

B. PEKCENT

100

46.3013

2. THEORETICAL PRODUCTION-- bas ed on existing facilities and:

- DENSITY FOKMULA (.5 X L X VOL.) = 417,960 lb: 3.6 1b/cf

- ACENCY CRITERIA RANGE (.B X VOL)" $92,8001 \mathrm{~b}$
and
$(2 \mathrm{X} \quad \mathrm{VOL})=232,200 \quad \mathrm{lb}$

3. FACTOKS CONTROLLING PRODUCTION:
A. POND VOL.: *116,100 C F
B. WATEK: NO DATA
C. FISH BIOMASS:
i. rearing density:
$-\mathbf{l b} / \mathbf{C F} \quad 0 \quad .4$

MODIFICATION COMMENTS: NONE KECOMMENDED. Land available, additional water questionable due to agricultural irrigation (see Hatchery Summary).

* Volume of currently used ponds

( ) Volume of total available pond space 
1. ACTUAL PKODUCTION:

\begin{tabular}{|c|c|c|}
\hline SPECIES & A. POUNDS & B. PEKCENT \\
\hline SP. CHINOOK & 27,100 & 35.3 \\
\hline S. STHD & $\begin{array}{r}49,700 \\
\ldots\end{array}$ & 64.7 \\
\hline TOTAL & 76,800 & --- \\
\hline
\end{tabular}

2. THEORETICAL PRODUCTION-- bas ed on existing facilities:

- D E N S I T Y FORMULA (.5 X L X V O L . ) = $\mathbf{1 1 6 , 2 0 0 ~ l ~ b : ~} 3.231$ b/cf

- ACENCY CKITEKIA KANGE $(.8 \text { X VOL })^{6}=\begin{array}{llllll}2 & 8,8 & 0 & 0 & 1 & b\end{array}$ and

$(2 \mathrm{x}$ VOL $)=72,801) l$ b

3. FACTORS CONTKOLLINC PKODUCTION:

A. POND VOL.: $* \mathbf{3 6 , 0 0 0} \mathrm{CF}$

B. WATEK: NO DATA

MODICICATION COMMENTS: NONE RECOMMENDED. Water is available, but space is limited.

* Volume of currently used ponds

( > Volume of total available pond space 
1. ACTUAL PRODUCTION:

SPECIES

F . CHINOOK

TOTAL
A. POUNDS 194,600 - . - $194,600,-.$.

194,600

B. PERCENT

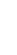

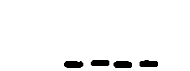

2. THEORETICAL PRODUCTION-- bas ed on existing facilities:

- DENSITY YOKMULA (.5 X L X VOL.)=306,100 lb: 1.8

- FLOW YOKMULA ( F X L X CPM $)=30,8001 \mathrm{~b}: 0.18 \mathrm{lb} / \mathbf{c f}$

- AGENCY CRITERIA RANGE (.8 X VOL $)=136,00001 \mathrm{~b}$

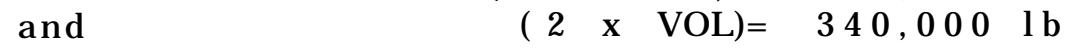

3. FACTOKS CONTKOLLING PKODUCTION:
A. P'OND VOL.: $* 170,078$ c $\mathrm{f}$
B. WATEK: $2995.5 \mathrm{gpm}$
i.enhance quality -treatment \& recirc.: $\quad(90 \%)$
c. FISH BIOMASS:
i decrease density: * $\mathrm{X}^{*}$
$-1 \mathrm{~b} / \mathrm{CF}: 1$. 1
$-1 \mathrm{~b} / \mathrm{C}$ P M : 64.9

MODIFICATION COMMENTS: Perhaps the current rearing density is too high. Construction of a settling pond to treat waste water prior to recirculation through filter beds and modification of the Spring Creek intake structure to collect all of the available water. This would allow a decrease in density. Ponds should be covered to decrease bird predation.

* Volume of currently used ponds

( ) Volume of total available pond space

$\mathrm{X}$ Action item 
1. ACTUAL PRODUCTION:

\author{
SPECIES \\ SP. CHINOOK \\ S. STHD
}

TOTAL

33,700

2. THEUKETICAL PRODUCTION-- b a s ed on existing facilities:

DENSITY FOKMULA $(.5 \mathrm{X}$ L X VOL. $)=435,0001 \mathrm{~b}: 3.2 \mathrm{Ib} / \mathbf{c f}$

FLOW FORMULA $(\mathrm{F} \times \mathrm{L} \times \mathrm{GPM})=36,9001 \mathrm{~b}: 0.28 \mathrm{lb} / \mathrm{cf}$

AGENCY CKITEKIA RANGE $(.8$ X VOL $)=107,1001 \mathrm{~b}$

and ( 2 x VOL)" $267,7001 \mathrm{~b}$

3. FACTOKS CONTROLLING PKODUCTION:

A. POND VOL.: *133,860 (142,563) c f

i. facilities not fully utilized * $X^{*}$

B. WATER: $3991 \mathrm{~g} \mathrm{p} \mathrm{m}$

I increase amnt. available: *X*

ii.enhance quality

- treatment and recirculation $* X *$

C. FISH BIOMASS:

i . rearing density

$-1 \mathrm{~b} / \mathrm{c} \mathrm{f}: 0.25$

$-1 \mathrm{~b} / \mathrm{C}$ P M : 8.4

MODIFICATION COMMENTS: Perhaps production could be increased if more water were available. Recirculation and temperature control may allow a three fold increase in production. Sources of additional land and water are available, however, existing facilities should be fully utilized before costly modifications are undertaken.

* Volume of currently used ponds

( ) Volume of total available pond space

$\mathrm{X}$ Action item 
HATCHEKY: WILLAKD NATIONAL FISH HATCHERY LOCATION CODE: 46

1. ACTUAL PRODUCTION:

$\begin{array}{lcc}\text { SPECIES } & \text { A. POUNDS } & \text { B. PERCENT } \\ \text { COHO } & 147,600 & 100 \\ \text { TOTAL } & 147,600 & \mathrm{~mm}--\end{array}$

2. THEORETICAL PRODUCTION-- bas ed on existing facilities:

- DENSITY FORMULA (.5 X L X VOL.)- $254,400 \mathrm{lb}: 2.65$ 1b/cf

- FLOW FOKMULA ( F X L X GPM)- $187,327 \mathrm{lb}: 1.95$ 1b/cf

- AGENCY CRITERIA RANGE (.8 X VOL)=' $\quad 76,800 \mathrm{lb}$ and $\quad(2 \times$ VOL $)=192,0001 \mathrm{~b}$

3. FACTORS CONTKOLLING PKODUCTION:
A. POND VOL.: *96,000 $(96,472)$ c f
B. WATEK: $24,460 \mathrm{gpm}$ i.enhance quality
- temperature: * $\mathrm{X} *$
C. FISH BIOMASS:

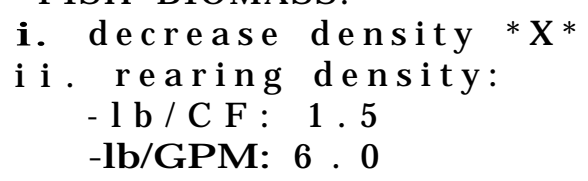

MODIFICATION COMMENTS: Perhaps densities are too high. Production of species reared may be enhanced by elevating water temperatures during winter and spring.

* Volume of currently used ponds

( ) Volume of total available pond space

X Action item 
HATCHERY: WIZARD FALLS TKOUT HATCHEKY LOCATION CODE: 47

1. ACTUAL PRODUCITON:

$\begin{array}{lcr}\text { SPECIES } & \text { A. POUNDS } & \text { B. PERCNET } \\ \text { KES. TKOUT } & \text { NO DATA } \ldots \ldots & \\ \text { TOTAL } & \text { NO DATA } & \end{array}$

2. THEORETICAL PRODUCTION-- based on existing facilities:

- A E N C Y CRITERIA RANGE (.8 X VOL) $=\begin{array}{llllll}3 & 0 & 3,2 & 0 & 0 & 1 \mathrm{~b}\end{array}$
and
$\left(\begin{array}{lll}2 & \mathrm{x} & \mathrm{VOL}\end{array}\right)=756,000 \mathrm{l} \mathrm{b}$

3. FACTORS CONTROLLING PKODLJCTION:

A. POND VOL.: $379,000 \mathrm{CF}$

B. WATEK: NO DATA

MODIFICATION COMMENTS: Wizard Falls Trout Hatchery produces no anadromous fish. Three dams exist on the Hetolius River, down river from the facility. Land is available for hatchery production: however most of the ten large raceways added in 1972 are not used because of IHN contamination, believed to be of river origin, and limited spring water. NONE RECOMMENDED.

* Volume of currently used ponds
( ) Volume of total available pond space
X Action item 
HATCHEKY: CHELAN FALLS/ TROUT HATCHERY LOCATION CODE 48

1. ACTUAL PKODUCTLON:
SPECIES
A. POUNDS
B. PERCENT

TOTAL

NO DATA

2. THEORETICAL PRODUCTION-- bas ed on existing facilities:

- DENSITY FOKMULA (.5 X L X VOL.)= NO DATA

3. FACTORS CONTROLLING PKODUCTLON:
A. POND VOL.: No Data
B. WATEK: $4475.3 \mathrm{gpm}$
i. reuse: * $x^{*}$

MODIFICATION COMMENTS: Chelan Falls and Chelan Trout are a joint facility funded by Chelan County PUD as mitigation for WDF and WDG. Land is available for expansion; however, spring water supplies are questionable due to ground water demands by local orchards. No modifications are recommended.

* Volume of currently used ponds

( > Volume of total available pond space.

X Action item 
1. ACTUAL PKODUCTION:

SPECIES SP. CHINOOK
A. POUNDS

$$
51,200
$$

$$
51,200
$$

B. PERCENT

100

2. THEOKETICAL PRODUCTION-- bas ed on existing facilities:

- DENSITY FOKMULA (.5 X L X VOL.) = $234,3001 \mathrm{~b}: 2.9$ 1b/cf

- AGENCY CRITERIA KA N G E (.8 X VOL $)=66,800 \mathrm{lb}$ $\begin{array}{llll}\text { and } & (2 \mathrm{x} \text { VOL) } & 167,400 & 1 \mathrm{~b}\end{array}$

3. FACTORS CONTKOLLINC PRODUCTION:
A. POND VOL.: 83688 cf
B. WATEK: No data
c. FISH BIOMASS:
i. rearing density
$-1 \mathrm{~b} / \mathrm{CY}: 0$. 6

MODIFICATION COMMENTS: NONE KECOMMENDED. L a nd is a vailable, however, the availability of additional water is limiting.

Groundwater development is not feasable, and additional river water is available In spring only.

* Volume of currently used ponds

( ) Volume of total available pond space

$X$ Action item 
HATCHEKY: LEAVENWOKTH NATIONAL FISH HATCHEKY LOCATION CODE: 50

1. ACTUAL PKODUCTION:

\author{
SPECIES \\ SP. CHINOOK \\ w. STHD
}

TOTAL

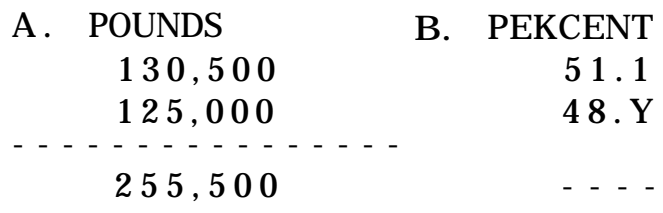

2. THEORETICAL PRODUCTION-- bas ed on existing facilities:

- DENSITY FORMULA (.5 X L X VOL.)= 905,100 l b: $3.2 \mathrm{lb} / \mathbf{c f}$

- FLOW FORMULA ( F X L X GPM $)=25,6201 \mathrm{~b}: 0.9 \mathrm{lb} / \mathbf{c f}$

- ACENCY CKITEKIA KANGE $(.8$ X VOL $)=226,1001 \mathrm{~b}$

and $(2 \mathrm{x}$ VOL $)=566,80001 \mathrm{~b}$

3. FACTORS CONTKOLLING PKODUCTION:

A. POND VOL.: 283,440 c f

B. WATEK: $2780.3 \mathrm{gpm}$

C. FISH BIOMASS:

i rearing density

$-1 b / C F: 0 \quad .9$

-lb/GPM:91.9

MODIFICATION COMMENTS: Space exists for facility expansion, however, it appears unlikely that enough water is available. Theoretically, an additional $10 \mathrm{cfs}$ of ground water should be available through additional wells; also, more river water is available In the spring. Those alternatives do not provide year arround sources. NONE RECOMMENDED.

* Volume of currently used ponds

( ) Volume of total available pond space

$\mathrm{X}$ Action item 
1. ACTUAL PKODUCTKON:

\section{SPECIES \\ s. STHD}

TOTAL
A. POUNDS
B. PEKCENT
17,100
17,100

2. THEOKETICAL PRODUCTION-- b a s ed on existing facilities:

- D E N S I T Y FORMULA (.5 X L X V O L . ) =

- AGENCY-CRITERIA R A N G E (.8 X VOL $)=$ $222,800 \quad 1 \mathrm{~b}: 3.4 \quad \mathbf{l b} / \mathbf{c f}$ and

3. FACTORS CONTKOLLING PKODUCTION:
A. POND VOL.: 65,520 c f
B. WATER: No Data
c. FISH BIOMASS:
i rearing density
$-1 \mathrm{~b} / \mathrm{CY}: 0.26$

MODIFICATION COMMENTS: None recommended. Land is available and water could possibly be supplied by additional wells.

* Volume of currently used pond6

( ) Volume of total available pond space

$\mathrm{X}$ Action item 
1. ACTUAL PKODUCTION:

SPECIES

S. STHU

TOTAL

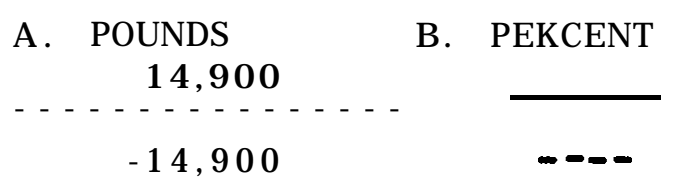

2. THEOKETICAL PRODUCTION-- b a s ed on existing facilities:

- DENSITY FOKMULA (.5 X L X VOL.)= 9,240 lb: 3.85 1b/cf

- AGENCY CKITEKIA KANGE (.8 X VOL)= 1,900 । b

$$
\begin{array}{lllllll}
\text { and } & (2 \mathrm{X} \text { VOL })-4,8 & 0 & 0 & 1 \mathrm{~b}
\end{array}
$$

3. FACTOKS CONTKOLLING PKODUCTION:
A. POND VOL.: 2,4000 c $\mathrm{f}$
B. WATEK: No Data
C. FISH BIOMASS:
i. decrease density: * $X^{*}$
i l. rearing density
$-1 \mathrm{~b} / \mathrm{CF}: 6$. 2

MODIFICATION COMMENTS: None recommended. Current densities are, perhaps, too high.

* Volume of currently used pond 6

( ) Volume of total available pond space

$\mathrm{X}$ Action item 
1. ACTUAL PKODUCTION:

SPECIES

TOTAL
A. POUNDS

NO DATA

2. THEOKETICAL PRODUCTION-- b a s ed on existing facilities:

- DENSITY FOKMULA (.5 X L X VOL.)= NO DATA

3. FACTOKS CONTKOLLINC PKODUCTION:
A. POND VOL.: NO DATA

B. WATER: 672.6 GPM

MODIFICATION COMMENTS: NONE RECOMMENDED.

* Volume of currently used ponds

( ) Volume of total available pond space

$X$ Action item 
1. ACTUAL PKODUCTION:

SPECIES

KES. TKOUT
A. POUNDS
NO DATA

B. PEKCENT 100

TOTAL

NO DATA

2. THEORETIAL PRODUCTION-- bas ed on existing facilities:

- A G E N C Y CRITERIA RANGE (.8 X VOL) $=11,00001 \mathrm{~b}$ and

(2 $\mathrm{X}$ VOL)- $27,6001 \mathrm{~b}$

3. FACTORS CONTKOLLING PKODUCTION:

A. POND VOLUME: 13,824 cf

B. WATER: $278 \mathrm{CPM}$

MODIFICATION COMMENTS: None recommended. No additional water is available. There is the possibility of reusing or recirculating that which is available.

* Volume of currently used ponds

( ) Volume of total available pond space

$X$ Action item 
1. ACTUAL PKODUCTION:

\author{
SPECIES \\ F. CHINOOK
}
A. POUNDS
106,000
B. PEKCENT
UNKNOWN

TOTAL

106,000

2. THEOKETICAL PRODUCTION-- b a s ed on existing facilities:

- DENSITY FOKMULA (.5 X L X VOL.) - $302,1001 \mathrm{~b}: 1.7$ 1b/cf

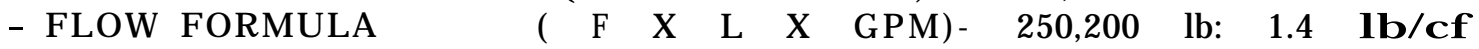

- AGENCY CKiTERIA KANGE (.8 X VOL) $=142,100$ lb and

3. FACTOKS CONTKOLLING PKODUCTION:

A. POND VOLUME: * 177,680 c f

B. WATEK: $49820.6 \mathrm{~g} \mathrm{pm}$

ii.enhance quality

- temperature: $*^{*} *$

C. FISH BIOMASS:

i. rearing density

$-1 \mathrm{~b} / \mathrm{C} \mathrm{F}: 0.6$

$-1 \mathrm{~b} / \mathrm{C} \mathrm{PM}: \quad 21.3$

MODIFICATION COMMENTS: There is perhaps a need for additional well water for fish rearing and tempering the temperature of river water used for holding adults. This would result in higher adult survival to spawning and ultimately greater smolt

production.

4,ESTIMATED INCREASED PRODUCTION (TOTAL): $40,000 \quad \mathrm{l}$ b

5. ESTIMATED CONSTRUCTION COSTS: $\$ 150,000$

6. ESTIMATED INCREASES IN OPERATIONS COSTS: Funds for 60,000 lb

of feed and $1 / 2$ man year of labor.

* Volume of currently used ponds

( ) Volume of total available pond space

$\mathrm{X}$ Action item 
1. ACTUAL PKODUCTION:

\section{SPECIES \\ SP CHINOOK \\ F. CHINOOK}

TOTAL

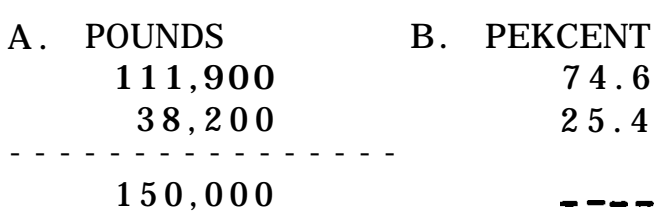

2. THEORETICAL PRODUCTION-- b a s ed on existing facilities:

- DENSITY FOKMULA (.5 X L X VOL.)= 5, 179,000 lb: $2.9 \mathrm{lb} / \mathrm{cf}$

- FLOW FORMULA (F X L X GPM $)=96,5001 \mathrm{~b}: 0.05 \mathrm{lb} / \mathrm{cf}$

- AGENCY CKITEKIA KANGE (.8 X VOL)- 1,437,400 lb and

$(2 \mathrm{x}$ VOL $)=3.593 .400 \mathrm{l} \quad \mathrm{b}$

3. FACTORS CONTROLLING PKODUCTION:
A. POND VOL.: *1,796,700 c f
i, facilities not fully utilized $*$ X*
B. WATEK: $11255.6-13452.9 \mathrm{gpm}$
1. reuse: * $\mathrm{x} *$
C. FISH BIOMASS:
i. rearing density
$-1 \mathrm{~b} / \mathrm{CF}$ :
0.08
$-1 \mathrm{~b} / \mathrm{CPM}: 13.3$

MODIFICATION COMMENTS: None recommended until current site is fully utilized. With the additional water recently added to the facilities the production could be increased. Additional land and water are available for expansion of the site rearing capacity. Combined with a recirculation system, production could be further increased. The water source is agricultural return flow and should not be considered for egg hatching.

* Volume of currently used ponds ( > Volume of total available pond space

$\mathrm{X}$ Action item 
1. ACTUAL PRODUCTION:
SPECIES
A. POUNDS
B. PERCENT

TOTAL

NO DATA

2. THEORETICAL PRODUCTION-- b a s ed o n existing facilities:

* DATA WERE NOT AVAILABLE TO BASE A CALCULATION UPON.

3. FACTOKS CONTROLLING YKODUCTION:

A. POND VOLUME: NO DATA

B. WATE K: NO DATA

C. FISH BIOMASS NO: DATA

MODIFICATION COMMENTS: Space and water from the Columbia Kiver are available for facility expansion. There arecurrently plans to develop the remaining $6 \mathrm{cfs}$ of the $10 \mathrm{cfs}$ of dam toe drain water, Warm river water during the summer may preclude attempts to increase production. Available rearing space for increased numbers of facility produced fingerlings is limited at the Turtle Rock $\mathrm{S}$ a te llite.

* Volume of currently used ponds

( > Volume of total available pond space

$X$ Action item 
1. ACTUAL PRODUCTION:
SPECIES
A. POUNDS
B. PEKCENT

TOTAL

2. THEORETICAL PRODUCTION-- b a s d on existing facilities :

- AGENCY CRITERIA RANGE (.8 X VOL)= $84,4001 \mathrm{~b}$
and
$(2 \mathrm{x}$ VOL) 211,101$) \mathrm{lb}$

3. FACTOKS CONTROLLING PKODUCTION:

A. POND VOLUME: 105,560 cf

B. WATEK: 4035.9 CPM

C. FISH BIOMASS: NO DATA

MODIFICATION COMMENTS: Land may be available, but not certain due to a proposed park site on the island. Water is available from the river, although temperatures may be too high seasonally. None recommended.

* Volume of currently used ponds

( ) Volume of total available pond space

$\mathrm{X}$ Action item 
1. ACTUAL PKODUCTION:

\section{SPECIES \\ RES. TKOUT}

TOTAL
A. POUNDS NO DATA

NO DATA
B. PEKCENT

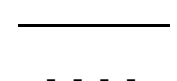

2. THEOKETICAL PRODUCTION-- b a s ed on existing facilities:

- AGENCY CKITEKIA KANGE $(.8 \mathrm{X}$ VOL $)=34,8001 \mathrm{~b}$ and

$(2 \mathrm{X}$ V O L $)=87,1001 \mathrm{~b}$

3. FACTORS CONTKOLLING PRODUCITON:
A. POND VOLUME : 43,537 cf
B. WATEK: 6502.2 GPM
C. FISH BIOMASS: NO DATA

MODIFICATION COMMENTS: NONE RECOMMENDED. No a ditional water is a vail a ble.

* Volume of currently used ponds

( ) Volume of total available pond space

$X$ Action item 
1. ACTUAL PRODUCTION:

$\begin{array}{lcc}\text { SPECIES } & \text { A. POUNDS } & \text { B. PERCENT } \\ \text { TOTAL } & \text { NO. DATA } & \end{array}$

2. THEORETICAL PRODUCTION--ba sed on existing facilities: *NO DATA AVAILABLE TO BASE ESTIMATES UPON

3. FACTORS CONTKOLLINC PRODUCTION:
A. POND VOLUME: NO DATA
B. WATEK: NO DATA
c. FISH BIOMASS: NO DATA

MODIFICATION COMMENTS: NONE RECOMMENDED.

\footnotetext{
* Volume of currently used ponds

( > Volume of total available pond space

$X$ Action item
} 
1. ACTUAL PKODUCTION:
SPECIES
SP. CHINOOL
F. CHI NOOK
s. STHD

TOTAL
A. POUNDS
43,600
900
97,600
B. PEKCENT
3 u. 7
0.6
68.7

2. THEOKETXCAL PRODUCTION-- b a s d o n existing facilities:

- FLOW FORMULA $(\mathrm{F} X \mathrm{~L}$ X CPM $>=115,100 \mathrm{l} \mathrm{b}$ :

3. FACTORS CONTROLLING PRODUCTION:
A. POND VOLUME : NO DATA
B. WATEK: 11883.4 - $14618.8 \mathrm{CPM}$
C. FISH BIOMASS:
i. rearing density
-1 b/CPM 12

MODIFICATION COMMENTS: Facility expansion is in progress based upon ample space and water (approximately 100 cfs).

* Volume of currently used ponds

( ) Volume of total available pond space

$X$ Action item 
1. ACTUAL PKODUCTION:

\section{SPECIES \\ SP. CHINOOK \\ $\mathrm{s} \mathrm{u}$. CHINOOK}

TOTAL
A. POUNDS
56,500
B. PEKCENT
UNKNOWN
UNKNOWN
$13,540 *(\mathrm{BY} 1980) \quad$ UNKNOWN

$$
70,040
$$

2. THEORETICAL PRODUCTION-- bas ed on existing facilitie s :

- DENSITY FORMULA (.5 X L X VOL. > $=215,2001 \mathrm{~b}: 2.9 \mathrm{lb} / \mathrm{cf}$

- AGENCY CRITEKIA RANGE (.8 X VOL. )= 59,400 lb and

$(2 \mathrm{X} \mathrm{VOL})=148,.4001 \mathrm{~b}$

3. FACTOKS CONTKOLLINC PRODUCTION:
A. POND VOLUME: $74,200 \mathrm{cf}$
B. WATEK: NO DATA
C. FISH BIOMASS:

i. rearing density

$$
-1 \mathrm{~b} / \mathrm{CF} \quad 0.76
$$

MODIFICATION COMMENTS: The Winthrop site has additional ground water and surface water potentials of $10 \mathrm{cfs}$ and $30 \mathrm{cfs}$ respectively. The ground water is about 49 degrees F and would require a low head lift, while the additional surface water would require additional ditch capacity. The areabetween Winthrop and Twisp is also thought to have good potential for shallow aquifers with abundant water supplies.

New adult collection and holding facilities were under construction at the time of our visit. USFWS had plans in 1981 to increase the station's production of spring chinook by constructing four $140^{\prime} \mathrm{x} 25^{\prime}$ dirt rearing ponds operated with infiltration gallery groundwater (Frederiksen et al. 1981). The Washington Department of Natural Hesources voiced some oposition to the plan at that time.

* Volume of currently used ponds

( ) Volume of total available pond space

$\mathrm{X}$ Action item 
1. ACTUAL PRODUCTION:

SPECIES

w. STHD

KES. TROUT
A. POUNDS
500
B. PEKCENT
UNKNOWN

TOTAL *NO RECENT PRODUCTION DUE TO IHN

2. THEOKETICAL PRODUCTION-- based on existing facilities:

- A G E N C Y CRITRIA RANGE (.8 X VOL) $=75,600$ Ib
and
$(2 \mathrm{x}$ VOL $)=189,100 \mathrm{ll}$

3. FACTORS CONTKOLLINC PRODUCTION:
A. POND VOLUME:
$94,600 \mathrm{cf}$
u WATEK: 11138.6 GPM

MODLFICATION COMMENTS: Closure contemplated due to extremely poor condition of facility. Agency may instead opt. for transfer of facility to the Yaklma Indian Tribe. See the hatchery summary for details of hatchery condition. Maintaining water quality is a problem. No quality water available. The present practice of producing non-salmonid species may introduce new diseases and other problems.

* Volume of currently used ponds

( ) Volume of total available pond space

$\mathrm{X}$ Action item 
1. ACTUAL PKODUCTION:

\section{SPECIES \\ SP. CHINOOK}

S. STHD

(* BY 19981$)$

TOTAL
A. POUNDS 109,337*
314,700

314,700
B. PEKCENT

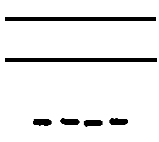

2. THEOKETICAL PROSUCTION-- b a s ed on existing facilities:

- DENSITY FOKMULA (.5 X L X VOL.)= 1,105,300 $1 \mathrm{~b}: 3.5 \mathrm{lb} / \mathbf{c f}$

- F L O W FORMULA $(\mathrm{F} X \mathrm{~L} \times \mathrm{GPIl})=$

- AGENCY CKITEKIA KANCE and $614,500 \mathrm{lb}$ :

$1 \mathrm{~b} / \mathrm{cf}$

3. FACTORS CONTKOLLINC PKODUCTION:

A. POND VOL.: "315,792 (373,542) cf

B. WATEK: $60,588 \mathrm{gpm}$

i. enhance quality

- treatment and recirculation --90X

c. FISH BIOMASS:

i. decrease density * $\mathrm{X}^{*}$

i i rearing density

$-1 \mathrm{~b} / \mathrm{CF} \quad 1$

$-1 \mathrm{~b} / \mathrm{GYM} 5.2$

MODIFICATION COMMENTS: NONE RECOMMENDED.

*Volume of currently used ponds

( ) Volume of total available pond space

$X$ Action item 
HATCHERY: EAGLE HATCHEKY (IDAHO FISH AND GAME) LOCATION CODE: 63

1. ACTUAL PRODUCTION;

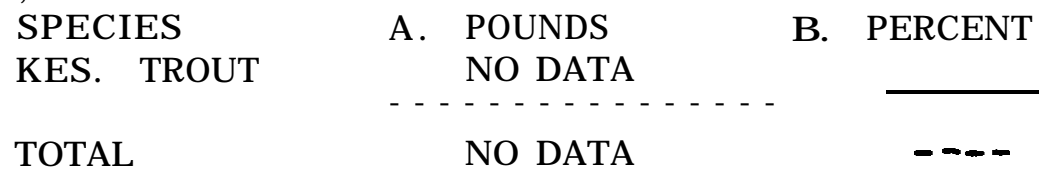

2. THEORETICAL PRODUCTION-- b a s ed on existing facilities :

- AGENCY CKITEKIA RANGE (.8 X VOL $)=42,2001 \mathrm{~b}$ and $\quad(2 \times$ VOL $)=105,40001 \mathrm{~b}$

3. FACTORS CONTROLLING PRODUCTION:

A. POND VOL.: $52,720 \mathrm{cf}$

B. WATEK: $883.4 \mathrm{gpm}$

i. increase amnt. available: "X"

MODIFICATION COMMENTS: These facilities a re near capacity trout production. Kemodeling with additions to the racewys is needed. Idaho Fish and Came owns ample land for expansion, but water availability and quality are major obstacles to increased production. NONE RECOMMENDED.

* Volume of currently used ponds

( ) Volume of total available pond space

$\mathrm{X}$ Action item 
1. ACTUAL PKODUCTION:

\author{
SPECIES \\ SP. CHINOOK \\ F. CHINOOK \\ S. STHD
}

TOTAL
A. POUNDS

7,610

$1-3,578$

135,629

183,700
B. PEKCENT

$\mathrm{N} / \mathrm{A}$

$\mathrm{N} / \mathrm{A}$

$\mathrm{N} / \mathrm{A}$

* Sp.Chinook produced for BY82; F.Chinook produced for BY81;

S.Sthd produced for BY79-BY82.

2. THEUKETICAL PRODUCTION-- b a s d on existing facilities:

* SEE COMMENTS IN MODIFICATIONS SECTION

3. FACTORS CONTROLLING PKODUCTION:
A. POND VOLUME: NO DATA

B. WATEK: $31524.7-39506.1$ GPM

MODIFICATION COMMENTS: These facilities were recently expanded and there is a need for time to evaluate the production potential of the site.

* Volume of currently used ponds

( ) Volume of total available pond space

X Action item 
1. ACTUAL PRODUCTION:

SPECIES
F. CHINOOK
COHO
KES. TKOUT

TOTAL
A. POUNDS

9,200

5,200 NO DATA
B. PEKCENT
UNKNOWN
UNKNOWN

2. THEOKETICAL PRODUCTION-- bas ed on existing facilities:

- AGENCY CKITEKIA KANGE $(.8$ X VOL $)=450,9001 \mathrm{~b}$ and

$(2 \mathrm{x}$ VOL $>=1,127,400 \mathrm{l}$ b

3 . FACTORS CONTROLLING PRODCUTION:
A. POND VOLUME: 563,680 c $\mathrm{f}$

B. WATER: $39013.5 \mathrm{CPM}$

i. increase amnt. available: $* X^{*}$

MODIFICATION COMMENTS: This site has land available, however water is limiting. Perhaps water could be reused or recirculated and tempered. The facility could use a total rehabilitation.

* Volume of currently used ponds

( ) Volume of total available pond space

$\mathrm{X}$ Action Item 
HATCHEKY: HAYDEN CREEK LOCATION CODE: 66 NAME: PMW

1. ACTUAL PKOOUCTION:

SPECIES

TOTAL
A. POUNDS

Hatchery No-Longer in Production

2. THEORETICAL PRODUCTION-- bas ed on existing facilities:

- A G E N C Y CRITERIA RANGE (.8 X VOL $>^{\prime}=489,700 \mathrm{l} \mathrm{b}$ and

$\left(\begin{array}{lll}2 & \mathrm{x} & \mathrm{VOL}\end{array}\right)=\mathbf{1 , 2 2 4 , 4 9 0} \mathrm{l}$ b

3. FACTOKS CONTKOLLING PRODUCTIONI
A. POND VOLUME:

B. WATEK:

$3587.4 \mathrm{gpm}$

MODIFICATION COMMENTS: Problems with the location of facility make improvements of dubious value. Need solution to Lemhi Kiver water rights issues. None recommended at present.

* Volume of currently used ponds

( ) Volume of total available pond space

$X$ Action item 
1. ACTUAL PKODUCTION:

$\begin{array}{lcc}\text { SPECIES } & \text { A. POUNDS } & \text { B. PEKCENT } \\ \text { SP. CHINOOK } & 22,100 & 55.8 \\ \text { s. STHD } & 17,500 & 44.2- \\ \text { TOTAL } & 39,600 & \end{array}$

2. THEOKETICAL PRODUCTION-- b a s ed on existing facilities:

- DENSITY FOKMULA (.5 X L X VOL.)= 99,100 l b: $3.15 \mathrm{lb} / \mathbf{c f}$

- FLOW FOKMULA $\quad\left(\begin{array}{llllllll}\mathrm{F} & \mathrm{X} & \mathrm{L} & \mathrm{X} & \mathrm{CPM}>= & 134,000 & \mathrm{lb}: & 4.3 \mathrm{lb} / \mathrm{cf}\end{array}\right.$

- ACENCY CKITEKIA KANGE (.8 X VOL $)=\begin{aligned} & 25,1 \\ & \text { K }\end{aligned}$ and

$(2 \times \mathrm{VOL})=62,8001 \mathrm{~b}$

3. FACTOKS CONTROLLIGN PRODUCTION:
A. POND VOLUME:
31,422 c f *
36,158 c f $* *$

B. WATEK:

15.695.1 g p m

i. enhance quality

- treatment C recirc.: $90 x$

c. FISH BIOMASS:

i. decrease density $* X *$

i i rearing density

$-\mathbf{l b} / \mathbf{C F} 1$. 3

$-1 \mathrm{~b} / \mathrm{CPM} 2.5$

MODIFICATION COMMENTS: Twelve acres of land are available for facilities expansion. Additional rearing capacity is limited by the available water supply and at present the supply of water is inadequate to provide for additional rearing capacity.

* Volume of currently used ponds

** Volume of total available pond space

$X$ Action item 
1. ACTUAL PKODUCTION:

SPECIES

TOTAL
A. POUNDS
B. PEKCENT

2. THEORETICAL PRODUCTION-- b a s ed on existing facilities:

- AGENCY CKITEKIA KANGE (.8 X VOL)= 43,200 l b

$$
\text { and } \quad(2 \mathrm{x} \text { VOL }>108,00001 \mathrm{~b}
$$

3. FACTORS CONTKOLLING PKODUCTION:
A. POND VOL.: 54,000 c f

B. WATEK: $22421.5 \mathrm{gpm}$

MODIFICATION COMMENTS: NONE KECOMMENDED, NEW FACILITY.

* Volume of currently used ponds

( ) Volume of total available pond space

$\mathrm{X}$ Action item 
1. ACTUAL PKODUCTION:

\author{
SPECIES \\ SP. CHINOOK \\ $\mathrm{COHO}$
}

TOTAL
A. POUNDS NO DATA NO DATA

New Facility
B. PEKCENT

2. THEORETICAL PKODUCTION-- bas ed on existing facilities:

- AGENCY CRITERIA KA N GE (.8 X VOL)'= $126,4001 \mathrm{~b}$ and

3. FACTOKS CONTKOLLING PKODUCTION:
A. POND VOLUME: $158,000 \mathrm{cf}$
B. WATER: $\mathbf{1 9 . 2 8 2 . 5} \mathrm{g} \mathrm{p} \mathrm{m}$

MODIFICATION COMMENTS: This is a recently constructed facility. Any expansion should wait until the productivity of the station can be established. Expansion prospects depend on the availability of additional land and water. NONE RECOMMENDED.

* Volume of currently used ponds

( ) Volume of total available pond space

$X$ Action item 
1. ACTUAL PRODUCTION:

\begin{tabular}{lcr} 
SPECIES & A. POUNDS & B. PERCENT \\
SP. CHINOOK & 10,034 & \\
su. CHINOOK & 5,850 & UNKNOWN \\
KES. TROUT & NO DATA & \\
\multicolumn{1}{l}{ TOTLA } & NO DATA &
\end{tabular}

2. THEORETICAL PRODUCTION--based on existing facilities:

- AGENCY CRITERIA KANGE (.8 X VOL $)=51,2001 \mathrm{~b}$ and

3. FACTOKS CONTROLLING PRODUCTION;
A. POND VOLUME: 64,000 cf
B. WATEK: $8968.6 \mathrm{CPM}$

MODIFICATION COMMENTS: NONE RECOMMENED> Additional facilities for summer chinook were planned for in the Lower Snake River Compensation Plan.

* Volume of currently used ponds

( ) Volume of total available pond space

$X$ Action item 
1. ACTUAL PRODUCTION:

SPECIES

S. STHD

TOTAL
A. POUNDS 181,150

B. PERCENT

100

2. THEORETICAL PRODUCTION-- b a s ed o n existing facilities :

- ACENCY CRITERIA RANGE (.8 X VOL $)=128,800 \mathrm{l}$ b and

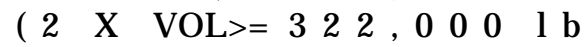

3. FACTORS CONTROLLING PRODUCTION:

A. POND VOLUME: $161,000 \mathrm{cf}$

B. WATEK: 59192.8 GPM

C. FISH BIOMASS:

i. rearing density

$-\mathbf{l b} / \mathbf{C F} \quad 1.13$

$-1 \mathrm{~b} / \mathrm{GYP} 13.06$

MODIFIATION COMMENTS: NONE RCOMMENDNDENDED Water is limiting as there is extreme competition for water rights (all available water is tied up, including hatchery waste water).

* Volume of currently used ponds

( ) Volume of total available pond space

$X$ Action item 
1. ACTUAL PRODUCTION:

$\begin{array}{lcc}\text { SPECIES } & \text { A. POUNDS } & \text { B. PEKCENT } \\ \text { S. STHI) } & \ldots & \\ & \text { TKAP AND RELEASE SITE } & -.\end{array}$

2. THEORETICAL PRODUCTIONb-a s ed o n existing facilities:

- AGENCY CRITERIA RANGE (.8 X VOL)= $47,3001 \mathrm{~b}$

and ( 2 x VOL $) 118,3001 \mathrm{~b}$

3. FACTOKS CONTKOLLING PRODUCTION:
A. POND VOLUME: 59,148 cf

B. WATEK: $8026.9 \mathrm{gpm}$

MODIFICATION COMMENTS: Increase and improve adult holding

facilities. This is presently a adult trap and juvenile release slte. Space is limited. None recommended.

* Volume of currently used ponds

( ) Volume of total available pond space

$\mathrm{X}$ Action item 
1. ACTUAL PRODUCTION:

$\begin{array}{lccc}\text { SPECIES } & \text { A. POUNDS } & \text { B. } & \text { PERCENT } \\ \text { S.CHINOOK } & 622 & & 3.0 \\ \text { SP. CHINOOK } & 19,900 & & 97.0 \\ \text { TOTAL } & 20,522^{*} & & \end{array}$

*Note: BY1981 release only

2. THEORETICAL PRODUCTION-- b a s ed o n e xisting facilities:

- AGENCY CKITEKIA KANCE $(.8$ X VOL $)=125,0001 \mathrm{~b}$ and

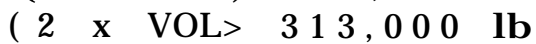

3. FACTORS CONTROLLING PRODUCTION:

A. POND VOLUME: 156,565 cf

B. WATER: $38565 \mathrm{~g} \mathrm{p} \mathrm{m}$

C. FISH BIOMASS:

MODIFICATION COMMENTS: Expansion is limited by. Idaho Power intends to increase production as needed. Facility is used as an adult trap, collection and spawning facility for Summer Steelhead, Summer Chinook and Spring Chinook. Steelhead are hatched and transfered to $\mathrm{Niagara,} \mathrm{Hagerman} \mathrm{NPH,} \mathrm{and} \mathrm{Buhl}$ facilities for rearing, then returned to be planted as smolts. Chinook are reared and released as smolts. None recommended.

* Volume of currently used ponds

( ) Volume of total available pond space

$X$ Action item 
ACTUAL PKODUCTION:
SPECIES
SP. CHINOOK
A. POUNDS
B. PERCENT
TOTAL
- . - . . . . . . . -
UNKNOWN

2. THEORETICAL PRODUCTION-- based on existing facilities:

- ACENCY CKITEKIA KANCE (.8 X VOL $>=256,0001 \mathrm{~b}$ and
$(2 \mathrm{x}$ VOL $)=640,0001 \mathrm{~b}$

3. FACTORS CONTROLLING PKODUCTION:

A. POND VOLUME: 320,000 cf

B. WATEK: $23,318.4 \mathrm{~g} \mathrm{p} \mathrm{m}$

MODIFICATION COMMENTS: Increases In production ar probably limited by the availability of eggs. Spring chinook adult survival is critically low and increased efforts must be made to improve their survival to spawning. This may be accomplished by use of medication, hormone treatments or improved handling methods and facilities. Space for expansion is limited.

Facilities are not presently producing to capacity becausef the above mentioned egg shortage. None recommeded.

* Volume of currently used ponds

( ) Volume of total available pond space

$X$ Action item 
HATCHERY: KEV RIVER POND

PROUUCTION:

$\begin{array}{lcc} & \text { POUNDS } & \text { B. PEKCENT } \\ \text { SP. CH NOOK } & 12,800 & \\ \text { TOTAL } & 12,800 & \end{array}$

2. THEORETICAL PRODUCTION-- b a s ed on existing facilities:

- AGENCY CKITEKIA RANGE (.I( X VOL)= $344,1001 \mathrm{~b}$ and $(2 \mathrm{x}$ VOL $)=860,2001 \mathrm{~b}$

3. FACTORS CONTROLLING PRODUCTION:

A. POND VOLUME: 430,1OO cf

B. WATEK: $6,726.5 \mathrm{~g} \mathrm{p} \mathrm{m}$

c. FISH BIOMASS:

1. rearing density

$-1 \mathrm{~b} / \mathrm{CF} \quad 0.03$

$-1 \mathrm{~b} / \mathrm{C}$ P M 1.9

MODIFICATION COMMENTS: If the amount of water shown on permit $(7,726 \mathrm{gpm})$ is available during the rearing period, production can be increased by 24,000 lb by simply increasing density and supplemental food.

4 .ESTIMATED INCREASED PRODUCTION (TOTAL): 24,000 lbs.

5. ESTIMATED INCREASES IN OPERATIONS COSTS: $36,000 \mathrm{lb}$ feed

* Volume of currently used ponds

( $>$ Volume of total available pond space

X Action item 
1. ACTUAL PKODUCTION:

$\begin{array}{lccc}\text { SPECIES } & \text { A. POUNDS } & \text { B. PEKCENT } \\ \text { SP. CHINOOK } & 149,000 & 100 \\ \text { TOTAL *NEW } & \text { FACILITY, FIGURES AKE PLANNED }\end{array}$

PKODUCTION.

2. THEORETICAL PRODUCTION-- bas ed on existing facilities:

* NEW FACILITIES, N/A

3. FACTOKS CONTKOLLINC PKODUCTION:
A. POND VOLUME: NO DATA
B. WATER: NO DATA
C. FISH BIOMASS: NO DATA

MODIFICATION COMMENTS: N/A NEW FACILITIES UNDER LOWER SNAKE COMPENSATION PLAN.

* Volume of currently used ponds

( ) Volume of total available pond space

$X \quad$ Action item 
1. ACTUAL PRODUCTION: SPECIES SP. CHINOOK F. CHINOOK

S. STHD

TOTAL
A. POUNDS

NO DATA

NO DATA

6,497
B. PEKCENT

UNKNOWN

UNKNOWN

2. THEORETICAL PRODUCITON-- bas ed o n existing facilities :

- A G E N C Y CRITERIA RANGE $(.8$ X VOL $)=246,200$ l b and

$(2 \times$ VOL $>=615,6001 \mathrm{~b}$

3. FACTORS CONTKOLLING PRODUCTION:

A. PO N D VOLUME: 307,786 c f

b. WATER: $33,632.3$ - 40,358.7 g p m

MODIFICATION COMMENTS: Land and water are available for expansion. Expansion plans are underway as part of

the Lower Snake Compensation Plan. None recommended.

* Volume of currently used ponds

( ) Volume of total available pond space

$X$ Action item 
1. ACTUAL PKODUCTION:

SPECIES

SP. CHINOOK

S. STHD

TOTAL
A. POUNDS NO DATA

NO DATA
B. PEKCENT - . . . . . . . . .

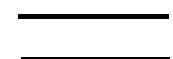

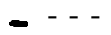

2. THEORETICAL PRODUCITON-- bas ed on existing facilities: PRODUCITON

3. FACTORS CONTKOLLINC PROUUCTION:

A. POND VOLUME: 110,257 cf WATER:

MODIFICATION COMMENTS: NONE RECOMMENDED. Expansion under THE A

* Volume of currently used ponds

( 1 Volume of total available pond space

$\mathrm{X}$ Action item 
1. ACTUAL PKODUCTION:

SYECIES

TOTAL $\quad * \mathrm{~N} / \mathrm{A}$
A. POUNDS

TRAP, ACLIMATION, KELEASE FACILITY

2. THEORETICAL PRODUCITON-- based on existing facilities:

$* \mathrm{~N} / \mathrm{A}$

3. FACTORS CONTKOLLING PKODUCTION:

* NO DATA

MODIFICATION COMMENTS: NONE RECOMMENDED.

* Volume of currently used ponds

( ) Volume of total available pond space $\mathrm{X}$ 
1. ACTUAL PKODUCTION:

$\begin{array}{lcc}\text { SPECIES } & \text { A. POUNDS } & \text { B. PEKCENT } \\ \text { S. STHD } & 107,100 & 100 \\ \text { TOTAL } & 107,100 & \end{array}$

2 . THEORETICAL PRODUCTIONb-as ed on existing facilities:

- DENSITY FOKMULA (.5 X L X VOL.) = 527,062 Ib: 3.7 lb/cf

- FLOW FOKMULA ( F X L X CPM $)=449,358 \mathrm{lb}: 3.4 \mathrm{lb} / \mathrm{cf}$

- AGENCY CKITEKIA RANGE (.8 X VOL)- $112,4001 \mathrm{~b}$ and ( $2 \mathrm{x}$ VOL) $281,10001 \mathrm{~b}$

3. FACTOKS CONTKOLLING PKODUCTION:

A. POND VOLUME: 140,550 cf

B. WATEK: $39,943 \mathrm{gpm}$

c. FISH BIOMASS:

i. rearing density

$-1 \mathrm{~b} / \mathrm{CF} \quad 0.76$

$-1 \mathrm{~b} / \mathrm{CPM} \quad 2.7$

MODIFICATION COMMENTS: New facilities are planned for under the Lower Snake Compensation Plan. None recommended;

* Volume of currently used ponds

( ) Volume of total available pond space

$\mathrm{X}$ Action item 
HATCHERY: RINGOLD SPRINGS STEELHEAD POND LOCATION CODE: 80

1. ACTUAL PKODUCTION:

\begin{tabular}{|c|c|c|}
\hline SPECIES & A. POUNDS & B. PERCENT \\
\hline s. STHD & $\begin{array}{r}35,798 \\
\ldots\end{array}$ & 100 \\
\hline TOTAL & 35,798 & \\
\hline
\end{tabular}

2. THEORETICAL PRODUCTION-- b a s ed on existing facilities:

- AGENCY CKITEKIA RANGE (.8 X VOL)' 1,338,200 lb and

$\left(\begin{array}{lll}2 & \mathrm{x} & \mathrm{VOL}\end{array}\right)=3,345,400 \mathrm{l}$ b

3. PACTOKS CONTKOLLING PRODUCTION:

A. POND VOLUME: 1,672,704 c $\mathrm{f}$

B. WATER: 2690.6 GPM

c. FISH BIOMASS:

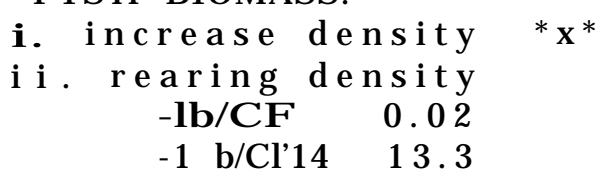

MODIFICATION COMMENTS:J Under the circumstances, this facility should be capable of considerably greater production of anadromous salmonids with an increase in water. The water is available. Because of the location of the facility, and the seasonal extremes in temperature, we recommend a doubling of the production. This will allow an evaluation of capacity.

4.ESTIMATED INCREASED PRODUCTION (TOTAL): $40,000 \mathrm{l}$ b

5. ESTIMATED CONSTRUCTION COSTS: \$120,000

6. ESTIMATED INCKEASES IN OPERATIONS COSTS: Funding for 60,000 $1 \mathrm{~b}$. of feed and $1 / 2 \mathrm{man}$ year labor.

* Volume of currently used ponds

( ) Volume of total available pond space

$\mathrm{X}$ Action item 
1. ACTUAL PKODUCTION:

SPECIES A. POUNDS B. PERCENT

TOTAL N/A * FACILITY IS A TRAPPING, ACCLIMATION, AND RELEASE SITE.

2. THEORECTICAL PRODUCITON-- bas ed on existing Facilities: $* \mathrm{~N} / \mathrm{A}$

3. FACTORS CONTROLLING PRODUCITON:
A. POND VOLUME: NO DATA

B. WATEK: NO DATA

MODIFICATION COMMENTS: Modifications to this facility will be undertaken as part of the Lower Snake Compensation Plan. No REOOMMENDATIONS.

* Volume of currently used ponds

( 1 Volume of total available pond space

$X$ Action item 